\title{
Maori Values Can Reinvigorate a New Zealand Philosophy
}

Piripi Whaanga

A thesis submitted to Victoria University of Wellington in fulfillment of the requirements for the degree of Master of Arts in Philosophy.

Philosophy Department

Victoria University of Wellington

2012 


\section{CONTENTS}

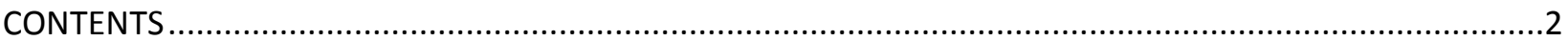

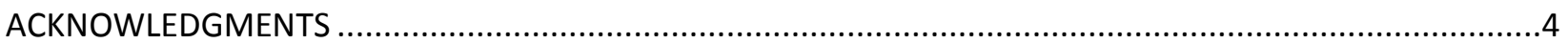

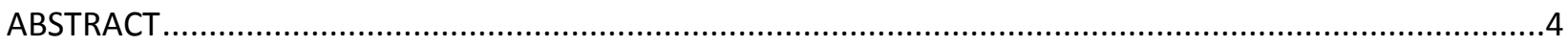

INTRODUCTION

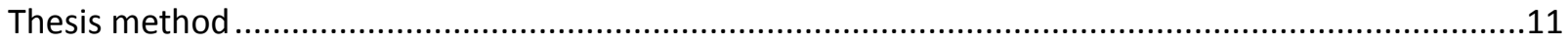

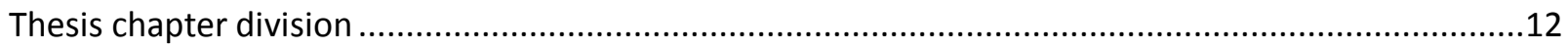

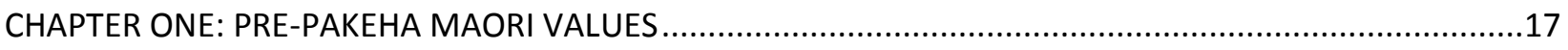

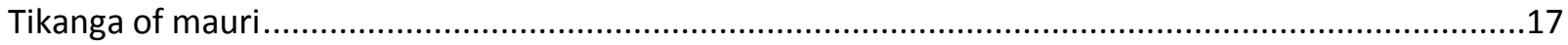

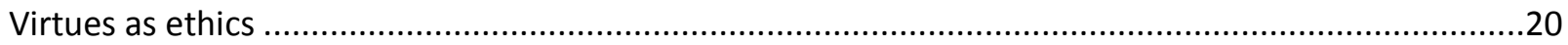

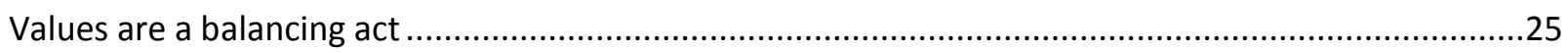

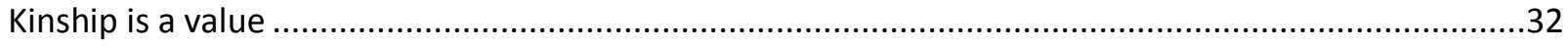

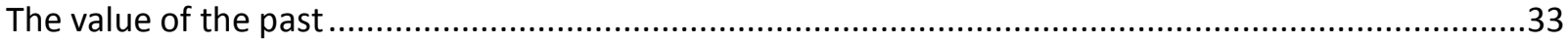

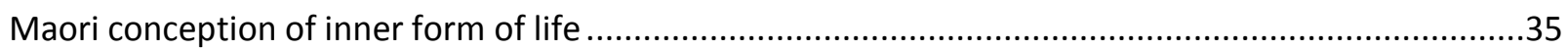

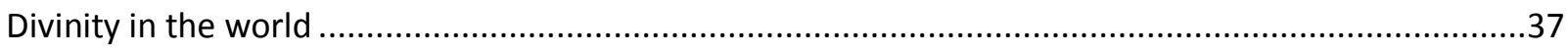

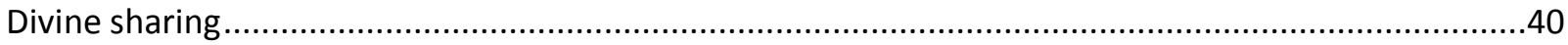

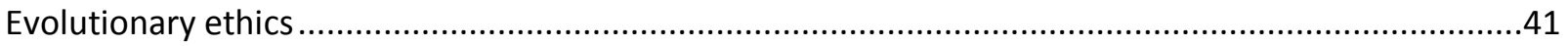

How do humans move from philosophic principles to knowing this world? .....................................44

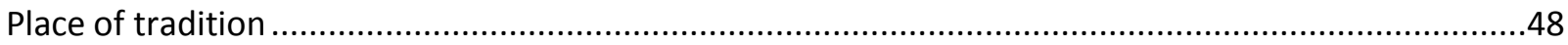

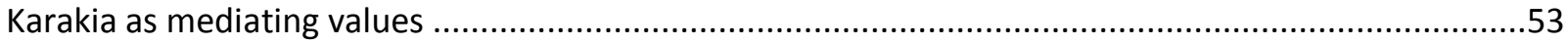

CHAPTER TWO: THE EFFECT OF PAKEHA VALUES ON MAORI VALUES …............................................58

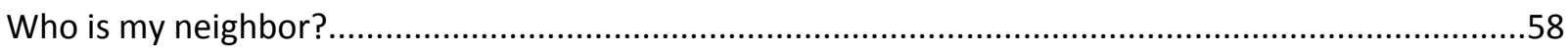

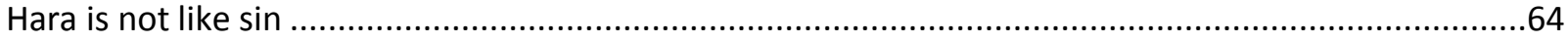

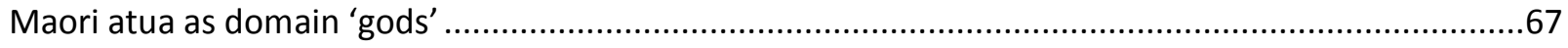

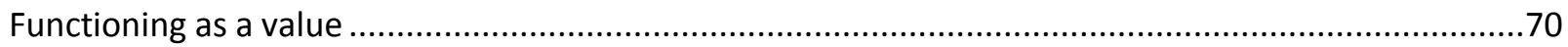

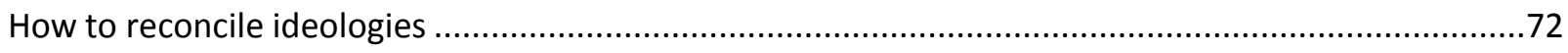

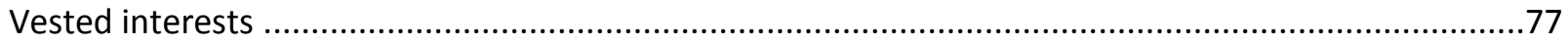

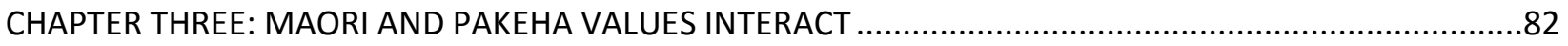

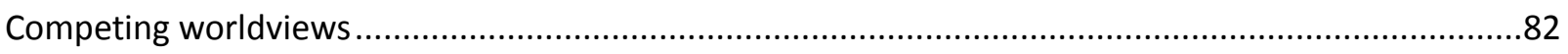

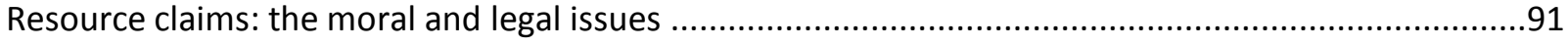

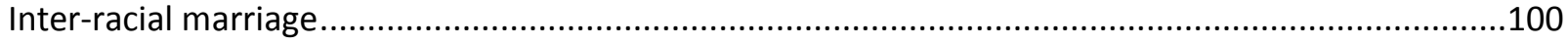


Surveyed beliefs or how New Zealanders see themselves and others ..............................................105

CHAPTER FOUR: TOWARDS A HARMONIOUS NEW ZEALAND PHILOSOPHY ........................................110

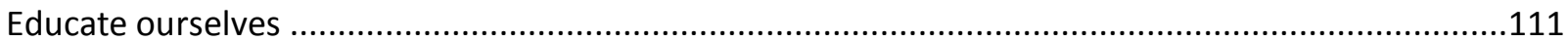

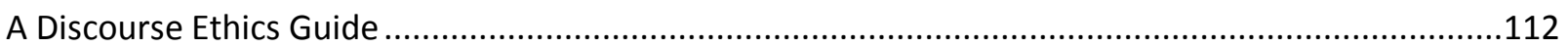

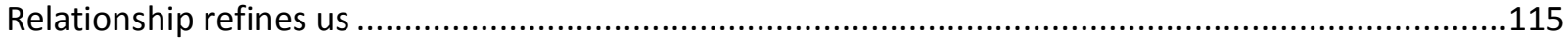

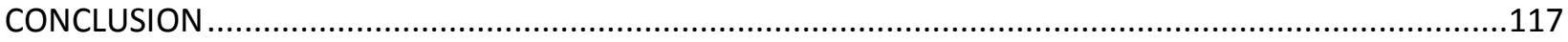

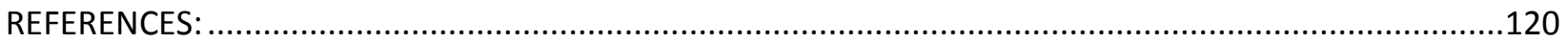

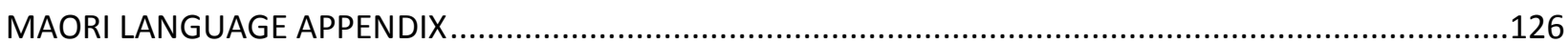




\section{ACKNOWLEDGMENTS}

Nga mihi aroha ki oku Maatua, Iharaira Titoko Whaanga raua ko Ellen Margurite (nee) O'Gorman.

I wish to acknowledge my parents, Doxy and Rita who had a heart for all people. Much respect to Jay Shaw for encouraging that heart in me and countless other students.

Thanks to the whanau Whaanga for home. Love to my wife for supporting my 'mature student' endeavours. These thoughts of mine are dedicated to the mokopuna of Aotearoa.

\section{ABSTRACT}

This thesis explores Maori values that can be seen in traditional Maori philosophy and attempts to define those values and how they are recognizable in Aotearoa/New Zealand. The thesis argues that through techniques such as discourse ethics where people agree to talk through differences, Maori values could be seen and incorporated in common New Zealand concepts, such as giving each other a 'fair go', for the betterment of the people and the land. This thesis argues for a new philosophy, a New Zealand philosophy.

What we value, we protect and teach so that it encourages, what we might call, an attitude of ethical behaviour in all people regardless of class, ethnicity or gender. This ethical attitude is itself part of the Maori value. However in Aotearoa, as around the world, there are differing normative behaviours because of the plurality of value systems. Sometimes dispute settlement techniques are needed to find ways to live together in harmony. My approach incorporates two international methods in a New Zealand perspective. These are: Jurgen Habermas's 'Discourse Ethics' based on his participatory conception of life where more 'having your say' not less, can solve the problems of contemporary living; and the ancient social science of Dharmasastra of Indian Philosophy which is the concept of dharma as support for the world. Where 'Discourse Ethics' invites communicative action, the concept of dharma goes further than Western normative codes by connecting human ethical ideals with a philosophical attitude towards the nature of the world, a type of moral code. I apply both these philosophic strategies to the quest for a moral conversation and moral justification between the world views of Maori and non Maori (Pakeha) to achieve cultural harmony both within and across cultures in this country. This moral conversation is the bed-rock of a New Zealand philosophy.

Chapter one outlines the traditional sources of Maori values and how they were linked to tikanga, a Maori concept expressed as the nature and function of a thing. This tikanga concept can be compared to the 'good' of a thing in Greek Philosophy. I then expand on this tikanga concept to show how the values encapsulated a Maori world view as a traditional philosophy of cosmological order. I discuss the place of tradition as a source of Maori knowledge and the importance of karakia (rituals) as mediation to connect tikanga (function) with the world view that is expressed through the practise of values. 
In Chapter Two I introduce a discussion on the values that the Europeans (Pakeha or non-Maori) brought with them as colonists and the effect these had on Maori philosophy. To illuminate these Pakeha and Maori values, I use Patterson and Perrett's comparison of Maori philosophy with that of the Western tradition of Plato and Aristotle, as well as Patterson's 'Maori Values' ${ }^{1}$ and his later development of a 'Pacific Philosophy.' ${ }^{2}$ I critique Patterson and Perrett's findings with contemporary tohunga (Maori ritual experts) regarding the use of karakia (rituals) to mediate values. It is in the realm of the metaphysical that karakia (as ritual mediation) meets with a major influence on Western values, Christianity.

I support the argument that it has been a predominantly one-sided process of adaptation, with Maori having done most of the adapting of Christian values into a Maori worldview. ${ }^{3}$ But I argue that for Pakeha, an openness to Maori values as ethical guides could be a fertile ground to nurture a moral conversation about common values and the attitudes that spring from them.

My thesis takes those differing values of Maori and Pakeha and engages in discourse ethics to bridge the gap. As Habermas' communicative action is based on not excluding any assertion but seeking to find common standards, I have looked at examples of contemporary New Zealand life, such as claims to the Waitangi Tribunal regarding New Zealand resources, to see if the seeds of communicative action are there. Habermas' common standards are: that rational agreement requires participants to back up special claims by reason not coercion; no person or assertion is excluded from the debate; all must be prepared to meet the argument halfway with a universalistic morality; values must be open to question in the light of rationally justified norms; participants need to value sincerity, understanding and reason as principles to live by.

I see the values of individuals being revealed through the policies and practices of the institutions of the nation they constitute and this is my practical method of making values and attitudes both explicit and able to be humanly found. For example the New Zealand justice system is examined through the values it practises in an attempt to explain the large number of Maori in prison. Maori law lecturer, Moana Jackson sees an antagonism between the individualistic punitive system New Zealand has inherited from Britain and the more communalistic values of Maori tradition. This theme is developed in Chapter Three which examines the contestation between Maori and Pakeha values and the hybrid norms that have evolved. Chapter Four attempts to find common philosophical ground between Maori and Pakeha and provides a unique model for resolving value disputes based on a New Zealand philosophy.

In this thesis I employ Dharmasastra (Indian moral code) as a comparative social science with Maori and Western philosophies to defuse a potential claim of bias by Maori or Pakeha against the use of each other's norms to determine common New Zealand values. I show how this Indian philosophy can fit well with the nuances of both Maori and Pakeha views through comparison and critique.

\footnotetext{
1 J Patterson, Exploring Maori Values (Wellington, Dunmore Publishing, 1992)

2 J Patterson, A Pacific Philosophy (Palmerston North, Dunmore Press, 2000)

${ }^{3} \mathrm{M}$ Henare, The Changing Images Of Nineteenth Century Maori Society- From Tribes to Nation, PhD Thesis (Auckland, Auckland University, 2003)
} 
Dharmasastra, as a social science that supports righteous actions, is close to the Maori dictionary meaning of a value as, 'something that is desired by the heart (ngakautia).' ${ }^{4}$ Even Western-based environmental philosophy acknowledges that intrinsic value rates along with instrumental value. When Maori and Pakeha values are aligned with Dharmasastra's fundamental goal of the betterment of society, the values can be seen to be common and thus have more chance of being harmonized in practical everyday actions. From a Pakeha perspective, giving one-another a 'fair go' is an important value, such as saying that 'Jack is as good as his master.' It means the ideal to strive for, is that everyone is given a fair chance in the New Zealand society. From a Maori perspective, an acceptable Pakeha value is one that is 'tika' or appropriate for this country and thus can be harmonised as a conceptual tool in a New Zealand philosophy.

An example of where these Maori and Pakeha perspectives meet in a 'moral conversation' is agreement on the continuing redress of historic injustice via treaty claims. Here pragmatism is the chief value but it also requires reasonableness, sincerity and patience.

\footnotetext{
${ }^{4}$ A Reed (compiled). T Karetu (revised), Concise Maori Dictionary, (Wellington, A. Reed Ltd., 1984), 14.
} 


\section{INTRODUCTION}

Contemporary New Zealand is facing a cultural crisis where Maori and Pakeha New Zealanders are increasingly seen as being at odds with each other. For this thesis, Maori is defined as any descendent of the original indigenous race who claims that ancestry. As this thesis is focused on Maori values, Pakeha (non-Maori) is a term that acquires its meaning in relation to what it is not - the focus of comparison, which is being Maori. Pakeha is not an ethnic category; the Maori who first encountered Pakeha saw them as a race. I follow the lead here of a social scientist ${ }^{5}$ and two historians. ${ }^{6}$ However following selfreported responses to a national survey of New Zealand values in 1989, Webster has adopted two more categories for Pakeha, that of 'New Zealander' and 'European' and one more category of Maori, for those who saw themselves as "Maori New Zealanders." To this I would add that people like me who acknowledge the values of both Maori and Pakeha ancestors are a new ethnicity. In the New Zealand Values Survey, the self-selected categories available to a person like me were 'above all Maori' or 'New Zealander above all.' (See Chapter Three 'Surveyed beliefs or how New Zealanders see themselves and others.')

A truly bi-cultural stance integrating Maori and Pakeha is sometimes not appreciated by either culture ${ }^{8}$ but has the seeds for realized harmony. A person of mixed ancestry may choose to acknowledge many streams but it is the culture in which they are able to integrate and practise their values, that influences the choice and how it is practised. A philosophical attitude of appreciating more than one point of view is sometimes drowned by mono-cultural bias. In order to avoid stereotyping in this thesis and any offence to the reader, the terms Maori and Pakeha do not imply homogeneous categories as there is much individual diversity. If I had taken part in the New Zealand Values Survey my Maori values would have opted for 'above all Maori,' but my integrated Pakeha/Maori values would have chosen 'New Zealander above all.'

There has been a growing Maori movement centered on 'tino rangatiratanga' defined by some as absolute authority for Maori to choose their own stance and govern themselves. ${ }^{9}$ One view is that this Maori movement needs to stay free of Western contagion. ${ }^{10}$ This independence of Maori thought has had an ambivalent history. Consequently there are a range of viewpoints about what constitutes being Maori. As my focus is on Maori values, my starting point is that being Maori is embracing a philosophy which enables people to become 'tangata whenua', literally people able to belong to this land.

\footnotetext{
${ }^{5}$ A Webster, Spiral of Values: The flow from survival values to global consciousness in New Zealand (Hawera, Alpha Publications, 2001)

${ }^{6}$ Belich 1996, King 2003.

${ }^{7}$ Webster, op.cit. 224.

${ }^{8} \mathrm{M}$ Ip, Being Maori Chinese: Mixed Identities,(Auckland, Auckland University Press, 2008)

${ }^{9}$ W Penetito, Tree of Opportunity - rethinking Pacific education,( Fiji, University of South Pacific: 2002)

${ }^{10} \mathrm{~N}$ Denzin, \& Y Lincoln and L Tuhiwai-Smith. Handbook of critical \& indigenous methodologies, (L.A. Sage, 2008)
} 
Through this relationship, Maori values obtain their normal expression. ${ }^{11}$ At its heart, belonging to the land goes beyond a utilitarian view of certain uses of the land or relationships with people. In Maori tradition, the land came first and was explained as a relationship of kinship, in such stories as Maui and his brothers and also how Tane was called to nurture his human offspring alongside their cousins living in harmony with the land known as the Earth Mother or Papatuanuku.

Another view of the relationship with land is summed up in a proverb: 'Te toto o te tangata, he kai; te oranga o te tangata, he whenua - the blood of man is supplied by food, the sustenance of man is supplied by land. ${ }^{12}$ One's life comes from the ancestors and their mana (influence) continues as they are buried in their land. But the experience of my father's generation was that a lot of the land was confiscated or unable to be farmed because of the Maori Land Court land succession system that has produced many uneconomic holdings amongst whanau. ${ }^{13}$ So the ideal of continued mana has not been the experience of my father's generation nor mine. Ancestral land title has also gone. Our family relationship is one of observing ancestral land from behind a fence and if we are lucky, being given permission to walk on our land at Nuhaka for whanau reunions. The maternal Pere land is near Gisborne and the paternal Whaanga land is between Wairoa and Gisborne. While this is a personal viewpoint, I believe generally the mana of Maori has suffered through their alienation from their land.

Some Pakeha views have challenged the traditional guardianship values of Maori in regard to New Zealand's resources. Those views have become public in recent years following the establishment of the Waitangi Tribunal in 1975 to examine tribal claims under the Treaty of Waitangi signed in 1840 between the British Crown and Maori hapu (now rendered as tribes). In recent times disharmony has centered on a government review of the Foreshore and Seabed Act 2005 that closed off legal appeals for traditional tribal access to coastal areas.

An Iwi (tribe) at the top of the South Island applied to the local district council for resource consent to use its sheltered bays for mussel-farming as adjacent Pakeha companies were doing. The consent was denied and so the Iwi applied to the Court of Appeal for permission to go the Maori Land Court and get a ruling there.

At issue was whether areas of the foreshore and seabed had the status of Maori customary land and whether such land could be converted into Maori freehold titles. The Court of Appeal gave permission for an application for a Maori Land Court ruling. However at this point the Labour government stepped in and rushed through legislation preventing any Iwi from going to the courts to appeal resource decisions. This hasty legislation birthed much Maori protest as well as a new Maori political party intent on repealing the Foreshore and Seabed Act. Four 'Maori Party' candidates were successful in the election of 2005. The National Party was able to form a coalition government of minor parties which included the Maori Party.

\footnotetext{
${ }^{11}$ Patterson 2000, op.cit. 14.

12 Riley 1990:6.6 c.f. Patterson, Exploring Maori Values (Wellington, Dunmore Publishing, 1992), 50.

${ }^{13}$ Land is divided in equal shares amongst children. Over generations this produces fractional parcels of land that become administrative liabilities.
} 
Part of the coalition agreement was to revisit the Foreshore and Seabed Act and in 2011 a revised bill to restore legal redress to Iwi became law. However some critics say it gives Maori special rights and that's not fair, while some Iwi say the heritage of British law values that underpins New Zealand's justice system is still defining Maori rights.

An example of this remote control can be seen in the personnel of the judiciary that up to a few years ago had British law lords reviewing New Zealand legal decisions through the Privy Council based in Britain. I believe the move to abolish the Privy Council in favour of a New Zealand Appeal Court made plain the bias that Maori have known through many unsuccessful petitions to Britain to have the Treaty of Waitangi recognized as New Zealand law. The Treaty is still not a binding accord and appears as an anomaly within New Zealand's British-based justice system. Law-makers have instead focused on the moral intent or principles of the Treaty, as the basis of a Maori/Pakeha value of partnership.

This debate can be seen as part of the inter-cultural conflict that is taking place around the world and social theorists say the contestation of different values is increasing. ${ }^{14}$ In New Zealand the Maori population of around fifteen percent has a youthful demographic (37\% of the total population are less than 15 years of age) and because of higher fertility rates, is expected to increase $(1.4 \%$ annually) in contrast to the aging European demographic (0.3\% annually). The Pacific Island population is also youthful and increasing in number (2.4\% annually) and the Asian annual increase of $3.4 \%$ is expected to outstrip the Maori percentage of the total population not long after 2026. As the Pakeha (defined by Statistics NZ as other than Asian, Maori or Pacific Island) population percentage increase lags behind other ethnicities, it is this group which will have to increasingly confront other worldviews and values, if they haven't done that already. ${ }^{15}$ For Maori, the on-going crisis has always been about honouring the original terms of settlement of the Treaty of Waitangi between Maori and representatives of the British Crown.

For over a hundred years, the New Zealand parliament, as successors to the British Crown, saw the Treaty as having no legal status containing no ethical guidelines for governing the country. Historians and social theorists expected an assimilation of sorts to occur in New Zealand, rather like a description at the close of the nineteenth century of the Maori as a dying race. ${ }^{16}$ Up until the middle part of the twentieth century, mainstream history described Maori culture as being on the fringes of New Zealand life. What was meant was that Maori had no say in the running of the country and had been pushed back to their rural kainga (villages) living a type of subsistence economy.

\footnotetext{
${ }^{14}$ R Cox \& M Schechter, The Political Economy of a Plural World: Critical Reflections on Power, Morals and Civilization (London; New York, Routledge, 2002) \& V Shiva, Staying Alive: Women, Ecology and Development (London, Zed Books, 1988)

${ }^{15}$ Statistics New Zealand, Hot Off The Press, Series 5, (Statistics New Zealand: Wellington, October 2007) Interestingly SNZ definition of Pakeha as other can include people from diverse countries such as India, Greece and South America as well as Europe.

${ }^{16}$ Michael King, Penguin History of New Zealand (Penguin: Auckland, 2003), 258.
} 
But for Maori culture and the values it contained, a different perspective had been unfolding. My father's life, like many of his generation from the 1920's, covered this journey from the margins of rural New Zealand to the cities. The values they practised and the changing environment in which they were lived out, showed how it was possible to have a moral conversation between Maori and Pakeha cultures, albeit unequally. Dad's life, like his generation, was one of living in mainstream Pakeha culture but participating in a Maori sub-world that had its own goals and values.

This is how my generation grew up. I learned the techniques of negotiation between Maori and Pakeha until the two worlds made sense for and in me. This practice was achieved by valuing an attitude of tolerance towards differing norms and then taking the actions that flowed out of this. My father's example to me was his support of his Anglican Church in mowing the lawns and helping sometimes to prepare the church before some Sunday services. Then he would usually accompany us and mum to Sunday mass at the Catholic Church. On his death bed he remained staunch to his view that there was just one river and he had chosen his waka (canoe) to cross in. This Maori philosophical view can be compared with Indian philosopher, Swami Vivekananda who has said, "The end of all religions is the realizing of God in the soul. That is the one universal religion. If there is one universal truth in all religions, I place it here - realizing God." ${ }^{17}$ His point like Dad's, is that if we focus on a common goal, we can cooperate more in life to realize that goal of oneness.

The necessity of oneness or commonality surfaces in the view of some modern social theorists who talk of essentialist views that see cross-cultural communication and exchange as real confrontation. ${ }^{18}$ Benhabib makes the comments in the context of reformulating a universalistic tradition in practical philosophy where a person's moral point of view comes from being able to question their own cultural norms. This means not only according moral respect to every person but seeing each as, "..... a unique individual with a certain life history, disposition and endowment, as well as needs and limitations." ${ }^{19}$ Here commonality is sought to resolve conflict.

This essentialism makes the acquisition of certain skills obligatory to define a culture or a person and without them the person struggles to fully join in cross-cultural communication. ${ }^{20}$ This is an important point if we take into consideration the fact that for many younger Maori, their tribal links are unknown. Statistics NZ reported that $20 \%$ of Maori didn't know their Iwi. ${ }^{21}$ Also some Maori social theorists say contemporary Maori culture suffers from this trait of 'one size fits all,' where lack of ability to speak Maori language means you are not accepted as a real Maori. So there is inter-cultural as well as crosscultural confrontation. ${ }^{22}$

\footnotetext{
17 J Shaw, Swami Vivekandanda as a philosopher (Kolkata, Ramakrishna Mission Institute of Culture, 2004 ), 8.

${ }^{18}$ Seyla Benhabib, The Claims of Culture: Equality and Diversity in the Global Era (Princeton: Princeton University Press, 2002), 35.

${ }^{19}$ Seyla Benhabib, Situating The Self (Routledge: New York, 1992), 10.

${ }^{20} \mathrm{M}$ Henare, Te Tangata te taonga te hau: Maori concepts of property (Wellington, Victoria University, 1998)

${ }^{21}$ Statistics New Zealand, 2001 Census: Iwi (2001) -reference report (Wellington, Statistics New Zealand, 2001)

${ }^{22}$ E Poata Smith, Ka tika a muri ka tika a mua? Maori protest politics and the treaty of Waitangi settlement process, in Tangata Tangata: Changing ethnic contours of New Zealand, P Spoonley, C Macpherson \& D Pearson (eds.) Southbank Victoria, Dunmore Press, 2004), 73-74.
} 
So I am faced with the philosophic position of how to reconcile both inter-cultural and cross-cultural misunderstandings.

\section{Thesis method}

I reconcile misunderstandings by focusing on values. A non-Maori definition of value is how important or useful something is. ${ }^{23} \mathrm{~A}$ Maori definition of valuing is 'kaingakau' where the prefix 'kai' can denote the agent who performs the work denoted by the verb. Kai can also mean to have full play. ${ }^{24}$ Here 'ngakau' means of the heart. So a Maori language meaning of a value goes beyond the non-Maori or Western view of utility, to a use desired by the heart. ${ }^{25}$ Williams says the heart mentioned here is not the physical object, rather the inclination, desire or spirit. ${ }^{26}$ Ngata says another synonym for value is 'whai tikanga,' the pursuit of what is appropriate or correct. ${ }^{27}$ Maori were not dogmatic or irrational within their value system where tikanga at a base level denoted the nature or function of a thing within an interrelated worldview. This point is focused on at the beginning of Chapter One. A philosophy that sees value in the pursuit of what is appropriate or functional can be compared favourably with the Greek philosophic tradition of seeing rationality as aiming at the Good. ${ }^{28}$ So Maori ethics could be said to be non-utilitarian in the Western sense. It could also be explained as not seeing ourselves in competition with others or with nature. Rather than trying to establish or defend our own authority, power or standing (mana), we can acknowledge the mana of all creatures and try to find ways of enhancing their mana while at the same time enhancing our own. ${ }^{29}$

This non-utilitarian value of not being in competition, is expressed in Indian Philosophy as an unselfish concept, such as with philosopher Vivekananda, who compares selfish actions to 'slave's work.' Even the thought of reward in helping others renders the action 'unrighteous. ${ }^{30}$ Furthermore his development of Advaita Vedantan philosophy rejected dichotomies that polarized believers, instead proposing that there were many rivers but only one sea at which all humanity would one day arrive. Vedanta encourages certain ideals as values to promote harmony as a goal in life. The one-ness that is stressed is of a divinity within the human person that can be realised in this life for personal, social and global harmony. ${ }^{31} \mathrm{~A}$ muted version of this unity is possible in contemporary Aotearoa using Maori values. But the many rivers of diversity need to be unblocked.

\footnotetext{
${ }^{23}$ Sansome, R (compiled) D.Reid (revised). The Oxford Junior Dictionary, 1988, Oxford University Press, Oxford), 165.

${ }^{24}$ Reed op.cit. 14.

${ }^{25}$ Reed op.cit.14.

${ }^{26} \mathrm{H}$ Williams, Dictionary of the Maori Language (Wellington: Legislation Direct, 1971), 227.

${ }^{27}$ H Ngata, English-Maori Dictionary (Wellington: Learning Media, 1996), 518.

${ }^{28}$ R. L. Nettleship (London: MacMillan and Co., 1897)

${ }^{29}$ John Patterson 2000, op.cit. 125.

${ }^{30}$ Jay Shaw 2004 op.cit. 18.

${ }^{31}$ Ibid, 29-30.
} 


\section{Thesis chapter division}

The thesis is divided into four chapters. Chapter One outlines pre-Pakeha contact traditional Maori values and their relationship with the environment, both organic and inorganic. I show how values grew out of a Maori view of a cosmological connection of being part of creation, all human and non-human linked by a life force or mauri. Tikanga (nature and function) were appropriate behaviour to balance different aspects of creation and so values emerged that supported this right behaviour. To further explain this Maori world view through comparative philosophy, I draw on some Eastern traditions. I also use the writings and oral tradition of two tohunga (ritual experts) to reinterpret the ancient values in contemporary practices to reveal the evolutionary nature of Maori philosophy. This evolutionary nature can be compared with dharma as a moral code ".....not fixed once for all, but must be learned in each generation from what is observed or allowed by learned men who are good and ever free from hatred and inordinate affect. ${ }^{32}$

In Chapter Two I look at the effect of Pakeha settler values. At the time of the colonial impact on New Zealand, the values were predominantly incorporated in the twin colonial ideologies of Imperialism and Christianity. Both could be described as ideologies with traits of superiority and self-interest. The settler values were best illustrated in territorial acquisition and control of resources, and after the British Queen's representatives negotiated a treaty at Waitangi in 1840, the ideology of Pakeha superiority soon pre-empted land battles that further hardened attitudes on the Maori side and the Pakeha settler side.

Legislation soon accomplished what battles could not, Pakeha settler domination that left Maori virtually landless and dispossessed of resources. Imperialism and Christianity could be seen as the default setting for 'God and Queen-appointed will', the nadir of which was the Tohunga Suppression Act of 1907 outlawing the transmission of tradition which represented Maori philosophy and the values it practised. $^{33}$

Chapter Three then looks at the result of that contestation, which I characterize as an interaction of Pakeha and Maori values, the seeds for unique New Zealand values. Patterson says there is a Pakeha philosophy that is different not only from the philosophy of the Maori but also the philosophies of the mostly European cultures from which Pakeha have sprung. ${ }^{34}$ The evolutionary nature of Maori philosophy that enabled their Polynesian ancestors to settle Aotearoa was also at work adapting to Western colonialism. An example given in Chapter Two, is of the holistic values of tikanga Maori (Maori function) adapting Christianity to reflect a Maori cosmology and enhance mana Maori (Maori standing) for a confident tribal and national identity in New Zealand communities. This successful adaptation shows the acceptance possible between Maori and Pakeha values and that as human beings we can always learn more. Henare and other Maori writers stress the inter-relationship of Maori concepts such as whanaungatanga (kinship), mana (authority or standing), tapu (set apart) and mauri (life-force) which enable a progressive philosophy or value system.

\footnotetext{
${ }^{32}$ Manu 2:1 c.f. in S Radhakrishnan (ed.) History of Philosophy Eastern and Western: Volume One (London: Allen \& Unwin Ltd, 1952), 117.

${ }^{33}$ Moon 2003

${ }^{34}$ Patterson 2000, Op.cit. 9.
} 
My claim is that the tikanga (function) of Maori philosophy allowed for new ways of seeing life and greatly assisted this melding of tribal lore into a cohesive pan-Maori philosophy that Durie says was also a response to nineteenth century Pakeha influence. ${ }^{35}$ My contention is that what is now termed 'Maori' philosophy was an amalgam of tribal lore that superficially differed sometimes with other tribes in ritual emphasis, language dialect and local cosmology, reflecting the different canoe traditions. This tribal diversity was also reflected in the arts. Tribal designs varied in decorations for personal ornaments as well as for tribal waka (canoe). Some tribes like Rongowhakaata near Gisborne, chose to paint designs inside and outside the meeting house rather than carve the wooden beams. Our house of Rongopai was built for the Ringatu prophet, Te Kooti and features paintings of our ancestors as well as leprechauns and soldiers climbing tall plants. However diverse, the traditions had common Polynesian roots before being affected by migratory settlement patterns in Aotearoa. Tribal chants and certain karakia (ritual mediation) still retain these interconnections or whakapapa between tribes as examples of philosophical associates. An example of tribal interconnection is found in 'Poi Atu Taku Poi,' a traditional waiata, that on one level of meaning, recounts the travels of a poi - which is a raupo (swamp plant) ball on the end of a short plaited string. The poi is twirled around the wrist and was used as an aid to dexterity in the use of hand weapons. 'Poi Atu' appears in the authoritative Nga Moteatea anthology as a journey linking different tribal areas from Patea in southern Taranaki, to Taupo of the central north island tribe of Tuwharetoa.

The poi also flies to Tauranga in the Mataatua (Bay of Plenty) area and ends in the Tainui (Waikato) area with the Maori king, Matutaera. The waiata is a valued method of remembering the unity of the tribes, as ancestors' names are mentioned along with the old names for districts. ${ }^{36}$ When used today on a ceremonial occasion, it expresses the commonality of tribal kinship as a philosophical Maori marker of the unity in lore.

Chapter Three also discusses intermarriage between Maori and Pakeha, for the rich ground of 'lived in' relationships between traditional values of Maori and Pakeha.

But for contemporary New Zealand, the settlement of Treaty of Waitangi resource claims has revealed the differences between Pakeha and Maori values as well as the unique accommodations being made as New Zealand values emerge in settlement agreements.

I use a comparison with Dharmasastra, the social science of Indian philosophy, to show how some uniquely New Zealand ways of working together have evolved out of Maori values and how they can give us the conceptual tools for a philosophy born of this country. An example is the prestige value that many Pakeha New Zealanders place on the haka as a sporting celebration. A New Zealand pride has emerged from what was a formerly tribal assertion of mana or warrior prowess.

\footnotetext{
${ }^{35} \mathrm{M}$ Durie, Te Mana Te Kawanatanga: The Politics of Maori Self-Determination, (Auckland: Oxford University Press New Zealand, 1998), 53-4.
}

\footnotetext{
${ }^{36}$ A Ngata \& P Te Hurinui, Nga Moteatea (Auckland, The Polynesian Society, 1961), 142-7; M McLean \& M Orbell, The Traditional Songs of the Maori (Auckland, Auckland University Press, 1979), 44-49.
} 
The potential to build a commonality on these Maori/Pakeha hybrid values for a New Zealand philosophy is developed in the concluding Chapter Four which suggests there can be unity in diversity.

I concentrate on bridging the gap between the worldviews of Maori and Pakeha and look at contemporary issues where these values can be seen to be operating. I use the discourse ethics of Habermas, ${ }^{37}$ specifically his central concepts of egalitarian reciprocity and universal respect, to show how the ethics can apply to a uniquely New Zealand way of evolving Maori tikanga as new ways of seeing life. I also compare Habermas' concept of universal respect with an Indian philosophical saying, 'that which exists is one, but sages call it by various names.'(ekam sadvipra bahudha vadanti) ${ }^{38}$ The point is made that if we agree a norm is applicable generally, we are basing this on an expectation of shared values and the discourse we engage in is with a universal audience. This is another way of saying that if we hold a value as important for all people, then it must be universalizable. This means don't carry out an action against another which you would not like carried out against yourself. It is a type of Kantian value principle. ${ }^{39}$ For the bi-cultural person such as my father and many of his generation with experience of two worldviews, the values that were negotiated were both an internalized and externalized experience. Internalized in the way the Maori and Pakeha ancestral streams of thinking sort themselves out in actual life situations of particular people, and externalized in the exchanges with other individuals. $^{40}$

I contend this is equivalent to the discourse with the universal audience of Habermas. ${ }^{41}$ But as tikanga, Maori values go beyond the utility of Western value to the desires of the heart, so the morality of any particular action is interconnected with social obligations.

This is unlike the ethics of Sartre where value follows actions. ${ }^{42}$ Here there is no rule to choose action by. You choose according to the situation and thereby value comes (sometimes called situational ethics). This is the existential proposition popularized by Sartre, who gave an example of a Frenchman wanting to enlist in the army and defend his country. Because he also had an aged mother at home to look after, he was torn between the two choices. Sartre believed no one choice was better but action had to be taken. After that action it can be shown what was valued. But Maori values are not like this. The values encouraged by Maori come from ideals which can only sometimes be realized, but that does not discredit the role of ideals in ethics. A rich source of information about Maori values comes from traditional sayings and proverbs that are used in oratory as powerful ethical precedents. So, rather than seeing Maori values as a fixed system of ethical standards, a philosophy based on ideals allows for flexibility in conflict.

\footnotetext{
37 Jurgen Habermas (1929 - ) studied post WW 2 at the Institute for Social Research at the University of Frankfurt.

38 J Shaw, Swami Vivekananda As A Philosopher, (Kolkata, Ramakrishna Mission Institute of Culture: 2004$), 6$.

${ }^{39}$ Immanuel Kant ( 1724 - 1804) German philosopher

${ }^{40}$ D Wood (ed.), On Paul Ricoeur Narrative and Interpretation, (London, Routledge: 1991), 51.

$41 \mathrm{~J}$ Habermas, The Theory of Communicative Action, Vol 1: The Reason and Rationalisation of Society (London: Heinemann Education, 1984), 26.

${ }^{42}$ Sartre (1905 - 1980) French philosopher and humanitarian
} 
This means proverbs and sayings can highlight a particular value in one context and promote its downfall in another.

"A principle of balance operates, so that, if there is any way of acting that allows both highlighted features to play their part, that is what should be done." ${ }^{43}$

Some commentators have said that Maori proverbs are not an ethical system but are 'situational responses. ${ }^{44}$ But over time certain proverbs have been more accepted and thus they do constitute an ethical system.

Overall the proverbs need to be balanced so it is left to the good sense and mana of those involved to find reasonable solutions of commonality. ${ }^{45}$

A feminist philosopher puts the ethical demands in the context that the reference is between real people not an application of universal principles. ${ }^{46}$ Benhabib describes the interaction as governed by the norms of equity and complementary reciprocity, where each is entitled to expect from the other behavior that recognizes "a concrete individual with specific needs, talents and capacities." ${ }^{47}$ Habermas and Benhabib are using a method to introduce commonality and I am following this goal by comparing Maori and Pakeha values. Benhabib adds to Habermasean philosophy by trying to individualize the people who make up the 'public' that Habermas is keen to give a voice to.

Also her representation of the disempowered woman's voice in a patriarchal world is complementary to the position of Maori in a Pakeha-centric New Zealand

Here then is a potential path for New Zealanders to engage in to sort out current misunderstandings about Treaty claims and use of resources, by emphasizing human social obligations. In Chapter Four I show how we first need to agree to engage in a moral conversation that guides our actions and then see our Maori and Pakeha cultures as supplying values for that guidance. Discourse ethics is particularly inclusive when applied to cultural values as Habermas says, "any universalistic morality is dependent upon a form of life that meets it halfway." ${ }^{48}$

It is important here to stress the role of Maori terms in the Maori language for which an appendix is provided. I borrow a concept from Witggenstein, 'language games.' He says in order to understand the meaning of a term you need an 'internal view' to know how to use the term to play the 'language game.' The speaking of a language is part of an activity or a form of life. Understanding a conversation about Maori values requires an insider's view of this activity as a form of life. ${ }^{49}$ By means of this moral

\footnotetext{
${ }^{43}$ Patterson 1992, op.cit. 75.

${ }^{44} \mathrm{P}$ Johansen, The Maori and his Religion in its Non-ritualistic Aspects (Copenhagen: Ejnar Mungksgaard, 1954), 163.

${ }^{45}$ Patterson 1992, op.cit. 75.

${ }^{46}$ C Gilligan \& J Murphy, Moral Development in Late Adolescence and Adulthood: A Critique and Reconstruction of Kohlberg's Theory in Human Development 23 (1980), 159.

47 Benhabib 1992, op.cit. 159.

48 J Habermas, Moral Consciousness and Communicative Action (Cambridge, Mass.: MIT Press, 1990$), 67$.

${ }^{49}$ L Wittgenstein, Philosophical Investigations (Oxford, Blackwell: 2001), 5 - 12.
} 
conversation New Zealanders can learn more of concrete situations that have values and attitudes with Maori and Pakeha aspects. And if we follow the principles of discourse ethics, we are required to back up our assertions with rational justification. If it is a conversation, then we will hear the other's wider framework of values in which their norm fits coherently. And only then with an 'insider's view' might both arrive at moral justification for each perspective. If there is no automatic agreement then it is up to us as humans with social obligations to find common values rooted in this country that can produce a norm about which we can find harmony.

This is the path of a New Zealand philosophy that I propose, to realise harmony between Maori and Pakeha values in Aotearoa/New Zealand. 


\section{CHAPTER ONE: PRE-PAKEHA MAORI VALUES}

This chapter outlines traditional Maori values and the relationship between humans and the natural world, seen as 'the environment.' The contemporary term 'environment' has come to mean everything around you that affects how you live and develop. ${ }^{50}$ It is a human-centric relationship. But as we shall see, traditional Maori cosmology had little distinction between humans and the natural world, both had direct kinship with their maker, Tane and both had reciprocal obligations through it. The contemporary environmental philosophy of the worldwide Green movement may have a scientific and ethical bias but it does not share belief in the kinship and reciprocity of Maori philosophy. In line with the quest for a New Zealand philosophy that incorporates Maori tradition, I begin with a Pakeha writer, John Patterson who specializes in ethics and is inspired by a Maori worldview. As a New Zealander with experience in both Pakeha and Maori worldviews, I critique Patterson's philosophy.

\section{Tikanga of mauri}

For Maori the relationship with the environment was and still is expressed as being part of creation, all linked by a life force or mauri. Tikanga is correct behaviour to balance different aspects of creation, so values emerged that were 'tika' or right. This 'tika' is not a legalistic right. A dictionary definition of right talks of a power or being in control. It can also mean permissible, to have a right to do $X$ means that it is not wrong to do $X{ }^{51}$ The rightness of 'tika' is more about natural from a tribal point of view and it is a term that combines evaluation and description. It is conducive to wellbeing. The wellbeing that is being talked about here is one where the whole of the person is integrated. There is no disagreement between the rationality of what the mind is proposing, what the spirit is willing to do and how the person's actions fulfill their function as a member of the community. An Indian writer says wellbeing is:

"....the sum total of obligations or duties by which one 'fits in' the natural and social world." 52

I agree with Johansen who said there was no distinction between customs as following the ancestors' practices and customs as deliberate models. Maori ethics are an aspect of man's nature, his humanity and belong to his tikanga. ${ }^{53}$ Here the tikanga is not something that is enforceable as a demand; rather it flows from following the model of ancestors and becomes a human custom which in turn is followed in subsequent generations.

Now rightness can also mean appropriate, correct or good, so let's look at a Maori view of good or 'pai' as quoted by Patterson.

\footnotetext{
${ }^{50}$ R Sansome, The Oxford Junior Dictionary (Oxford, Oxford University Press: 1988), 50.

51 T Mautner, The Penguin Dictionary of Philosophy (2000, Penguin Books, USA.), 487.

52 H Patyal, The Term Dharma: Its Scope in History of Philosophy Eastern and Western Volume One (London, George Allen \& Unwin Ltd: 1952), 24.

53 Johansen 1954, op.cit. 172. c.f. Patterson 1992, op.cit. 102.
} 
A weaver, Erenora Puketapu-Hetet, describes her work as demanding respect of the purpose as well as the materials. She views the flax or harakeke she uses as embodying the mauri or life-force of TaneMahuta, the god of the forest, who is also an ancestor of Maori.

Through her weaving she must give another dimension to this mauri so that it is still a thing of beauty, and so she injects into it a new value. Thus work as respect means materials are never just, "means to some selfish end of the worker but always with respect, as means to some worthy end, as befits one's ancestors." 54

This concept of adding respect as a value, does not compare well with the current value system in New Zealand where workers have become increasingly subject to accepting lower wages and poor working conditions because they are afraid of losing their jobs. There are exceptions to this climate of fear, but many workers are marginalized by an attitude of 'dog eat dog.' This is more a case of degrading value than adding value. Injecting new value into their work and respecting the purpose as well as the work materials, is a home-grown value system New Zealanders would do well to follow.

I saw this concept of respect as a boy, practised in our Maori culture club, Te Aroha. Costumes were needed, such as flax puipui or skirts and bodices and tipari (headbands). Club members worked with local farmers to source flax and the skilled artists taught how to scrape and cut the flax and dye with natural materials. Similarly both men and women were encouraged to plait the fibres for the costumes. The harvesting of the flax was accompanied by karakia and leftovers were burned. This was to show respect for the materials and their intended purpose. Scraps were buried or burned so that there would not be misuse. Because of the awareness throughout the harvesting and weaving, club-members wore their costumes with respect and pride.

I claim 'pai' as meaning good, can be intensified by the use of 'tino' to 'tino pai,' meaning 'very good.' Similarly the weaving of the flax works on the good to raise this good to a thing of beauty. This is just one example of values flowing from appropriate or 'tika' attitudes to what is good and functioning in right relationships.

Aristotle believed the good in any creature was located in the unimpeded exercise of the capacities and functions of the particular species. Aristotle stated that practical rationality makes our means right, in contrast to excellence of character or moral virtue which makes the ends right. ${ }^{55}$ Here practical rationality is the ability to perceive what is good or useful for living well. ${ }^{56}$ In a commentary on Plato's Republic, both Aristotle and Plato are said to picture social life as a:

"domain in which all forms of art or specialized skill have their several fields, each with its own peculiar end: medicine producing health, the art of war victory, business wealth, and so on." 57

\footnotetext{
${ }^{54}$ Patterson 1992, op.cit. 19.

${ }^{55}$ F Miller, Reason Papers No.9 Winter 1983 (USA, The Reason Foundation, 1983), 30. (Nicomachean Ethics 6.12 , 114a, 7-9)

56 Ibid. 30 .

${ }^{57}$ R Nettleship, Lectures on the Republic of Plato, Chapter XX111, The Good as the Highest Object of Knowledge (London, MacMillan and Co.,1897),207.
} 
Nettleship said over a hundred years ago, the function of a human being was to live for something as a creature of means and ends. Plato said a human being had a 'good.' Everything that is done is regarded by the constitution of human nature as a means to something. This is the inseparable connection in Plato and Aristotle between reason and the good.

"The rationality of man means that he is a creature who has ideals and who cannot help having them." 58

Patterson has interpreted the word tikanga, as the nature or function of a thing and says this could be seen as knowledge. He says life was lived as a shared project with a holistic approach. This is a Platonic approach, where the ultimate goal for human beings is knowledge of the 'Good.' Plato's pupil, Aristotle carried on this philosophy, locating the 'Good' in human virtues. ${ }^{59}$

"For the savior of society the one thing needful is certain and immediate knowledge of values, the ends which all life, private or public, should realize." ${ }^{60}$

Plato elevated ideals to goals where the attainment may have been seldom achieved but nevertheless worthy. In Plato's Republic, the debate is about how people are to be encouraged to act for the 'Good' of all. Plato says only by ideals can his Greek State achieve a common unity. Plato uses the historical figure of Socrates to say the ideals allow for a judgment of our own happiness and unhappiness according to the standard which they exhibit and the degree in which we resemble them, but not with any view of showing that they could exist in fact. Plato uses the comparison of a painter who draws a picture of a perfectly beautiful man and is then criticized for not being able to show that any such man could ever have existed. Ideals are never fully realised in language because the word expresses more than the fact and whatever a person may think, always, in the nature of things, there is a falling short of the truth. It is the possibility of realizing the 'Good' through ideals which mattered most to Plato.

What is common between Plato's Republic and my argument for finding harmony in New Zealand today, is in the ideal of the unity of the citizens as the greatest 'Good'. This unity can resolve the conflict that exists within New Zealand society. But we need more than Plato's ideals. New Zealand needs individuals using perception and insight in social planning freely choosing Aristotelean virtuous acts as ends in themselves chosen for their own sakes. ${ }^{61}$

But there needs to be allowance for degrees of realization, as people slowly come to understand how we affect each other for good and bad by our actions and thoughts. In today's jargon, we are all on a journey and at different stages of development. When I was young I focused on my needs. As I grew up I understood that was selfish and I saw a bigger perspective into which I, as a human being, fitted. I see this understanding of how human beings affect each other as an attitude that human beings can adopt. The following diagram of an inverted triangle illustrates these different stages of development as progress to what is good for the world.

\footnotetext{
58 Ibid, 219-220.

${ }^{59}$ Patterson 1992, op.cit. $102-109$.

${ }^{60}$ R Nettleship, op.cit. 226.

${ }^{61}$ Miller, op.cit. 29. (Nicomachean Ethics 2).
} 
This is comparable to Plato's view that the ultimate virtue of human beings was knowledge of the Good. Human beings progress from the lower apex, and the effects of their interactions spread out just like a triangle.

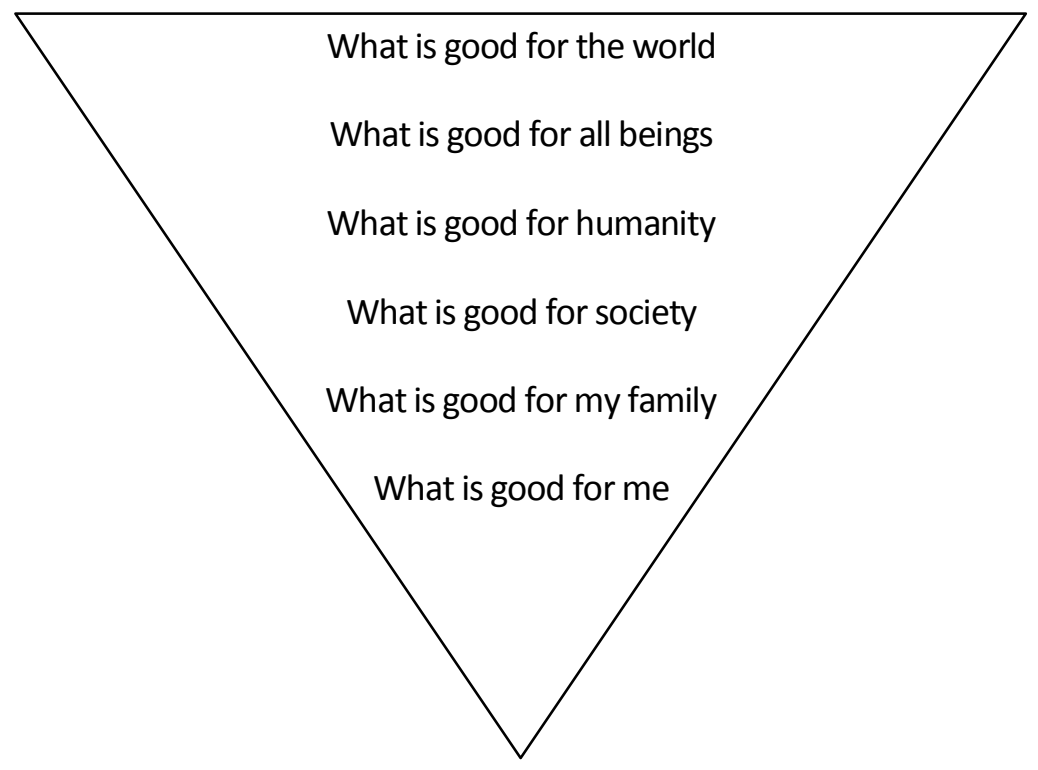

\section{Virtues as ethics}

This model of progressive 'good' seems to be the basis for the claim that traditional Maori ethics were based on a philosophy of virtues. Here the absence of prescriptive biblical codes in Maori was not a lack of morals but rather a cultivation of a certain excellence of character, that of a rangatira or noble person as having certain characteristics. ${ }^{62}$

What ought to be done by this character is personified in stories such as those of my Kahungunu tribe. Contrary to the bravery of some other ancestors, Kahungunu the ancestor was known for manaakitanga, providing for his people. He was said to have impressed the ancestress of Te Mahia area, Rongomaiwahine with his ability to dive for paua and stay underwater for a long time by sticking the shellfish to his body. He also provided large quantities of the food staple fern-root, by climbing the hills and rolling the fern down in big bundles. A song tells of another ancestress, Nga Nuhaka who gave her name to the river that provides nourishment to the many marae along her banks. Nga Nuhaka is also remembered as a model of faithfulness to her husband Ruawharo, the priest or tohunga of the founding waka Takitimu of our tribe. ${ }^{63}$ Other tribes have their high ranking female ancestors too, Muriwhenua who was the matriarch of one of Northern tribes and Hinemoa who is famous in the Rotorua area for her fidelity to Tutanekai. He played a koauau (nose flute) so skillfully that she swam some distance across the lake to be with him.

\footnotetext{
${ }^{62}$ R. Perrett, in R.C. Solomon and K.M. Higgins (eds.) From Africa to Zen: An Invitation of World Philosophy, $2^{\text {nd }}$ ed. (Lanham: Rowman \& Littlefield, 2003), 255-268.

${ }^{63}$ Tommy Taurima, composer of Ruawharo. "Ruawharo, anei to hoa wahine a Nga Nuhaka e..."
} 
All these ancestors were rangatira who provided models of excellence.

The literal meaning of rangatira is 'to weave a group of people together': a definition of leadership that reveals the interdependent and collectivist nature of Maori society. ${ }^{64}$

Patterson says the ideal values were embodied in the noble chief and quotes two Pakeha writers. ${ }^{65}$ Best has a values list that includes: being industrious; brave; hospitable; a good leader in war; expert at carving; weaving; canoe-making and house-making; good at settling disputes and knowledgeable about the boundaries of tribal land. ${ }^{66}$ Johansen adds, possessing a fearless mind, being contemptuous of death and magnanimous, 'living the life of the whole tribe', honourable in agreements, liberal, being of few words but weighty in speech, kind, knowing how to manaaki (love and honour) people and possessing maia (steadfastness). ${ }^{67}$

But it should not be seen that the ideal values were of a classical Maori time. Here are some of my contemporary examples of these values being practised.

Industrious and knowledgeable about building community through Maori skills:

Te Puea, the grand-daughter of the second Maori King Tawhiao, reinvigorated the Tainui tribe through regular hui and established the monthly round of meeting on different marae that continues today. Te Puea also restored the art of canoe-making in the 1930's encouraging her own tribe and others to carve waka. The results were celebrated during elaborate festivities on the Waikato river near the King's marae of Turangawaewae .

\section{A good leader in war:}

Colonel Awatere led the Maori Battalion to battle in World War 2 adapting tribal rivalry to military tactics that allowed Maori flexibility under a central leadership.

A different form of leadership was shown by the non-violent philosophy of Te Whiti and Tohu Kakahi in peacefully protesting the confiscation of their Taranaki land in the late 1800's. Their encouragement of tribes-people ploughing up the survey lines of settlers and the sowing of crops in the furrows, led to the sacking of their village, Parihaka in 1881. It should be noted this philosophy of peaceful civil disobedience preceded both Mahatma Gandhi and Martin Luther King. ${ }^{68}$

As a strategy, civil disobedience did not stop the settlers taking over the land but only incensed the colonial government to take even tougher methods with Taranaki Maori who did not want to sell their land.

\footnotetext{
64 J.C.Kennedy, Leadership and Culture in New Zealand (New Zealand: Lincoln University, 2000) c.f. D Pfeifer \& M Love, Leadership in Aotearoa New Zealand: A cross-cultural study, in Prism 2, 2004, 2.

${ }^{65}$ Patterson 1992, op.cit. 100-115.

${ }^{66}$ E Best, Maori Religion and Mythology, Part 11 (Wellington: Govt. Printer, 1982), 242.

67 Johansen 1954, op.cit. 181-4.

${ }^{68}$ R Buchanan, The Parihaka Album(Wellington: Huia Publishers, 2009)
} 
And when those who resisted the taking of their land by force were arrested and shipped off to prison, their land was confiscated. But as a leadership value of 'living the whole life of the tribe,' as Johansen puts it, the non-violent philosophy of Te Whiti and Tohu Kakahi birthed an attitude of tribal unity and continuing care for the land. More will be said in later chapters about contemporary events regarding the legacy of Parihaka.

As my argument is that by finding common ground between Maori and Pakeha, we can cultivate bicultural harmony, it might pay to examine that particular value of 'settling disputes' that Best quotes.

To begin with, the Maori that Best observed in the nineteenth century largely still had their values intact within the practise of their norms. Dispute between Maori involved utu and balance. Utu is reciprocity and not the usually perceived Pakeha idea of revenge. The Maori idea is that some underlying polarity in the universe is upset from time to time and it needs to be restored or balanced. The balance is usually upset between kin and outsiders and it is the mana (as prestige, power or authority) that needs to be brought back into balance. In a case of injury, intentional or not, utu could be seen as a virtue to restore the mana of a kinship group. But utu also operates where a kinsman has suffered personal misfortune, perhaps by infringing tapu (sacred prohibition) and the relatives arrive to take away his possessions and maybe even his family. The anthropologist, Peter Buck is quoted as saying he took part in such a display of utu which is called muru (removal). Here the kinsman's mana was seen as inadequate to protect his possessions and loved ones and the victim may have even been pleased that extent of their mana was recognized. We cannot finish this discussion of utu without referring to another important aspect it has of restoring balance in peaceful exchanges where there is obligation to respond to a gift, at least with one of equal value. The celebration associated with gift-giving or giving hospitality is called manaaki which is derived from the word 'mana' (prestige) and the word to encourage 'aki.' Thus an important component of restoring balance is encouraging or building up mana. ${ }^{69}$

In this matter of settling disputes, it is bringing harmony as balance that is central to any modern reconstruction of using and understanding Maori values. Without understanding the interconnections between mana and tapu and the philosophical attitudes required, there can be no balance. A virtue ethics' view of Maori values however uses the concept of tapu to modify mana as a protective device. If virtues are character traits that can promote human flourishing, then the use of mana in conjunction with tapu harmonizes human interaction with each other and with the environment also. So a Maori 'virtues' philosophy needs balance and harmony.

A Maori lawyer describes the relationship as,

"Ko te tapu te mana o nga atua." Tapu is the mana of the gods (as spiritual powers). ${ }^{70}$

\footnotetext{
${ }^{69}$ Patterson 1992, op.cit. 104-121.

${ }^{70}$ M Jackson, The Maori And The Criminal Justice System, He Whaipaanga Hou - A New Perspective, Part 2 (Wellington: Department of Justice, 1988), 43.
} 
This view of Maori values as virtue ethics has an evolutionary concept that leads towards this ideal. It is examined in more depth later on in this chapter under the term 'tikanga' or the nature or function of a thing. Tikanga is the Maori explanation for the holistic nature behind the values. If we reflect on the contemporary examples of leadership used, for instance with being good at war, we can see what was called for in World War Two was different from the Taranaki land confiscations. Both situations called for leadership but the means of showing the ideals were different. What was appropriate or 'tika' varied but the end goal of both was to restore the mana of the kinship group. The resolution of conflict where tikanga varies over what is appropriate, means that no simple ascending scale of values can as yet be clearly defined. But I would reiterate that it is balancing damaged mana that needs to be understood and the role tapu plays in this.

Patterson says knowledge of peace-making was valued over the arts of warfare because it is mentioned first in the traditions of Tane fetching the three baskets of knowledge. He says the emphasis on the warlike nature of traditional Maori may have been more influenced by Christian teachings of peace. Willingness to compromise is a Maori virtue that is rather unexpected, given past wrongs and suffering. ${ }^{71}$ Modern-day peace-making, as pragmatic compromise, is a base for a 'moral conversation' for a New Zealand philosophy of harmony that I outline in Chapter Four.

So in terms of Maori values needed for settling disputes today, Pakeha might need to be helped to find common values that roughly align with the concepts of mana, mauri and tapu so that a dialogue can begin on the same page. If tapu, mauri and mana are too foreign as concepts for a Pakeha worldview then perhaps seeing each human being as possessing a certain dignity may help in comparison. Similarly the Maori concept of human descent from the gods may be seen by some as sharing in a 'spark of divinity,' but again substitution of the term 'dignity' in human beings may be more helpful. ${ }^{72}$

Patterson says there was no Maori legalistic code of rules, rather Maori lore as following the conduct of the ancestors, the model of the kinship group. Johansen puts it as Maori not having a distinction between man's nature and customs, one flowed out of the other, both theory and practice. This is how I understand tikanga, the nature or function of a thing and the tikanga of a human being includes conduct. Tikanga is an inner form of life that manifests itself in one's conduct. In Exploring Maori Values Maori are said to become full human beings by following the customs or common practices of the ancestors. This is the same philosophy of Aristotle, agent-centered rather than an action-centered philosophy, that one 'ought to' be, rather than follow the performing of acts or obeying of rules. Maori achieved this by the imitation of virtuous people. ${ }^{73}$

\footnotetext{
${ }^{71}$ Patterson 1992, op.cit. 163.

72 Shaw, J. Man and Freedom: A Comparative Study, in Bulletin of the Ramakrishna Mission Institute of Culture, Calcutta: Ramakrishna Mission Institute, 2000), 413.

${ }^{73}$ Patterson 1992, op.cit. 102-107.
} 
I believe this view of virtue is comparable with the Dharmasastra of Indian philosophy. This social science of righteousness was inspired by the sacred books or the Vedas collated thousands of years ago. One of the four Vedic principles of Indian philosophy is that of following the example of virtuous people to learn unselfishness. The other principles are: association with holy places; study of holy scriptures; and dedication.

This Vedic view of virtue may be foreign to non-Western minds but it was developed to resolve conflicts from different perspectives. At the bottom of the hierarchy are worldly possessions (artha) and the pleasures of life (karma). Both are subservient to righteous action (dharma) and practise of dharma will lead to liberation or realization (moksa) which is the ultimate goal of life. ${ }^{74}$

In short Dharmasastra was the practical application of spiritual doctrines for the betterment of society. A contemporary view is that it is most feasible when all the people involved in contentious issues are properly educated in righteousness. Even the king or head of state has specific moral duties. ${ }^{75}$

"Dharmasastra is a comprehensive code to regular human conduct in accordance with the unalterable scheme of Creation, and to enable everyone to fulfill the purpose of his birth. The whole life of Man, considered as both an individual and as a member of groups as well as man's relation to his fellow men, to the rest of animated creation, to superhuman beings, to cosmos, generally and ultimately to God come within the purview of Dharmassastra." 76

Seeing Maori values as a comparable social science or philosophy of virtue ethics is the seed for evolutionary Aotearoan ideals and a New Zealand philosophy. These ideals contain a Maori world-view that was not dualistic but incorporated polar opposites e.g. hoa/friend, riri/anger = hoariri/enemy or angry friend.

This was an example of a philosophy of mutual interdependence that was not exclusive. This mutuality incorporated the whole environment, with the human, holistically needing to be in balance with all. Mauri was the life-principle and mana was the power or authority that enabled creativity to be exercised. To deal with challenges to this mana, the principle of tapu dealt with infringements. Thus tapu incorporated the ethical demands of the virtues and rangatira were seen as set-apart virtuous people practising noble ideals. In sum, Maori philosophy defined both a closed and open society by performing in a certain way. Closed, in that leadership was circumscribed by a ritual/religious aspect but open, in that political leadership was by personal achievement. Maori values stressed what you were rather than what you did, character as opposed to action. Good intention was embodied in character traits so the philosophy was neither pragmatism nor materialism. An example of this living up to the ideals of virtues comes from Aristotelean philosophy where the character of a person is given a primary place in the ethical system.

\footnotetext{
74 J Shaw, Swami Vivekananda As A Philosopher, (Kolkata, Ramakrishna Mission Institute of Culture: 2004$), 3$.

${ }^{75}$ V N Jha, (ed.) Dharmasastra and Social Awareness (Delhi: Sri Satguru Publications, 1996), 1-8.

${ }^{76}$ Jha, op. cit. 2.
} 
"It is fundamentally concerned with what sort of person one ought to be, what sort of life one ought to live, rather than with what acts one ought to perform or what rules one ought to obey." 77

Virtue ethics had their origin in the ancient world particularly in the writings of Aristotle and Plato. The Routledge Encyclopedia of Philosophy says the virtues concept was revived in the twentieth century following a critical article by G.E. Anscombe which deplored modern ethics and suggested a return to the virtues. Modern virtue theory includes virtue ethics, which is about how we should act and live. For Socrates the virtues were a unity possessed in knowledge alone. He asked the question, "How should one love?" and answered, "virtuously." Aristotle believed the virtues would be possessed by the man of "practical wisdom and the key virtue would be reciprocity." 78

Aristotle described virtue ethics as characteristics a human being must have in order to live a good life where the good life is where one performs one's functions to the fullest. ${ }^{79}$

An example of this 'ought' is my dad who was not a trained tohunga (expert) in ritual or whaikorero (speech making). So when my company's broadcasting training school was to be opened, the tohunga invited was unable to attend and I asked my father to conduct the ceremony. He said, "What shall I do?" I asked him to go around the rooms and declare our school's intention to provide the best broadcasting training for its Maori students, which he did.

The Ngati Toa chief, Te Rauparaha is an historical example of living a life 'one ought to.' Oral tradition says he was part of a band which was constricted by competition for land in the Waikato and chose to trek down the North Island looking for opportunity. On the way they faced hardships and this was the making of the man, who while being pursued by enemies, composed the haka icon of survival, Ka Mate. Ngati Toa now resides as a tribe in the Porirua area of Wellington. ${ }^{80}$

Te Rauparaha was not born a rangatira but had to combine what natural skills he had with a determination of character. He knew what he ought to do for the people from the models of leadership he saw around him. Rather than accept a safe but crowded home environment, he chose to strike out for fresher pastures. He risked danger by travelling through enemy tribal lands and even put his personal mana in jeopardy by hiding beneath a woman. Te Rauparaha performed his functions to the fullest.

\section{Values are a balancing act}

We can use the experience of an ancestor, Te Rauparaha as an example of values as exemplified in character that became a practice to be followed, a tradition. In Te Rauparaha's case, this manifestation of values has gone beyond the tribe into New Zealand folk-lore as the haka best associated with sporting endeavour. $\mathrm{Ka}$ Mate is comparable to a national song complete with patriotic feeling.

\footnotetext{
77 Patterson 1992, op.cit. 103.

${ }^{78}$ E Craig (ed.) Routledge Encyclopedia of Philosophy (New York, Routledge: 1998), 622-23.

${ }^{79}$ Aristotle wrote ten scripts concerning how man (sic) should best live. This practical ethical behaviour came to be known as Nicomachean Ethics.

${ }^{80} \mathrm{H}$ Collins, Ka Mate Ka Ora: The Spirit of Te Rauparaha (Wellington, Steele Roberts, 2009)
} 
It is significant to New Zealanders because it is used to psych a team to play with more passion. It also intimidates opposing teams who have no comparable psychological display of aggression. But most of all I believe it allows a European sensibility to Maori savagery to be temporarily put to one side in the interests of national pride where Maori and Pakeha values embrace in common purpose. The value of courage and persistence personified by Te Rauparaha is now valued as common pride in New Zealand. This pride is now expressed by Pakeha as well as Maori and is a pointer to a common value that has merged bi-culturally and so can be used to bring harmony in a New Zealand philosophy. A Maori proverb from my tribal area of Kahungunu (Hawke's Bay to the Wairarapa) could sum up the values associated with the haka Ka Mate. It says 'bravery is not individual, but collective.' Te Rauparaha's survival was as much about tribal mana as individual mana and it is the collective that gives the warrior courage. ${ }^{81}$ Although the days of tribal war have gone, the haka of Te Rauparaha is a favourite of the New Zealand All Black rugby team and for sporting fans it embodies mighty feats on the sporting field.

Respect for the Maori as a warrior race, pride in New Zealand Pakeha for being accepted alongside Maori as co-sharers of this country and bi-cultural tolerance on public display are just a few of the values now associated with Ka Mate.

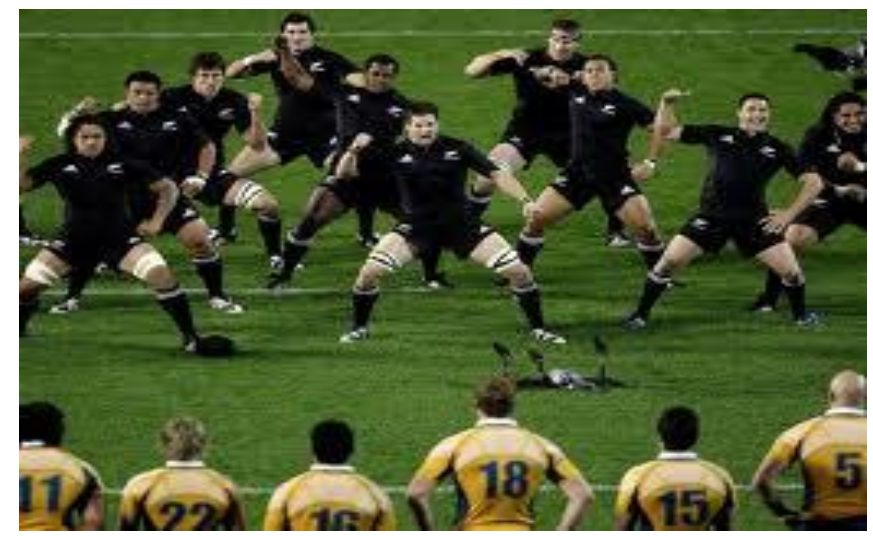

The All Black haka challenges the Australian rugby team.

On a lighter note, tribal mana is still to the fore at the national Aotearoa Festival where there is much tribal competition through haka and such posture displays, along with contemporary action songs and traditional waiata. Groups compete regionally over a two year period to gain selection for the nationals and most are centered on inter-tribal groupings with some overseas groups, such as Maori living in Australia. The purpose is to uplift the mana of each other's dedication to Maori culture despite the fierce competition on the stage. The hosting of the event is also a competition of mana to outdo previous hosts in terms of organization and spirit. Overall the Aotearoa Festival has provided a fertile ground for performers and composers of contemporary Maori waiata as well as a revival and celebration of older chants, hymns, haka and oratory. The Festival's values can be seen to promote maia or steadfastness.

${ }^{81}$ Patterson 1992, op.cit. 57. 
For Maori purposes, the Aotearoa Festival is like a national university focusing on the usage of Maori language and the tikanga or functions that accompany it. So as well as maia (steadfastness), other values practised are aroha (love and compassion), whakapehapeha (pride) and whakaata (reflection). This function as a national gathering place is amplified by the regional and tribal nature of the competition and the two year cycle which culminates in national category winners. And of course the winners get to travel overseas to other indigenous festivals. All the while, the Maori language compositions of the groups reveal the ability of 'te reo Maori' (the Maori voice) to handle contemporary issues within a popular entertainment medium.

The Aotearoa Festival is a modern day example of Maori ingenuity, like those Maori who composed waiata to provide encouragement for the soldiers of World War Two and their communities. It was also no surprise during the first half of the twentieth century to hear the Maori language handle such diverse topics as the delights of the shearing gang and the education of Maori. The twentieth century composers were merely following on from their ancestors who used song and chant to record their passage through the world. Remnants of these compositions were seen as poetry and said to be 'scattered pieces from many canoe areas. $^{82}$

It has been said that by following the customs of the ancestors, Maori became full human beings. In essence, the tikanga of human beings includes their appearance, conduct, habits and also an inner form of life that manifests in behavior. The foregoing example of the Aotearoa Festival reflects this inner form of expression as it is a feeling of heart and soul being joined. This could also be said when I attend an event in the Maori world and am moved to speak or perform a waiata or chant. For me as a university student, becoming a full human being has taken on new significance in my writing from a Maori and Pakeha bi-cultural perspective on philosophy, sociology, socio-linguistics, anthropology and religion. My tikanga as my nature has become visible in questions I pose about values in which my Maori dad and Irish mum raised me to respect people.

"Our tikanga is not simply how we behave - it is something within us that makes us behave the way we do."

The quality stressed here, is being in accord with human nature, in this case, tribal nature where being natural is quite literally being Maori:

"......and hence reasonable and correct. To a Maori this means being in accord with customs and common practice." 83

Tikanga is rational in that it is functional within the Maori philosophy. That is if we take the Greek view that rationality is aiming at the Good. I have stated Aristotle's view that releasing the Good in one's life required one to perform one's functions to the fullest. And as being in accord with customs was being functional, therefore to Maori, tikanga was rational.

\footnotetext{
${ }^{82}$ A. Ngata \& P Te Hurinui, Nga Moteatea Part 1, (Auckland, The Polynesian Society Inc., 1959), title page.

${ }^{83}$ Patterson 1992, op. cit. 103.
} 
Mana is the connection between humans and the environment, as a universal good enabling the attitude to treat all humans and non-human as kin. This valuing of non-human kin is to be emphasized, as it encompasses the suffering of sensate beings not just humans. This caring attitude earns 'soft' mana. So we can see here a connection between a value and mana and the environment in which to practise it.

Maori philosophy describes a mutual interdependence of living holistically with the environment. The concept of mana enabled a standing by human beings both within the social and the natural world environment. Even now the practice of mana remains a universal good that needs to be commonly understood by both Maori and Pakeha because it secures a common social obligation of fellow human beings in this country. ${ }^{84}$

A tohunga (ritual expert), Maori Marsden describes the creation of the world as coming from the stirrings of Io, the creator and First Cause in Te Korekore (potentiality), Te Po (becoming) and Te Ao Marama (the world of being). Thus the whakapapa (genealogy) of the gods includes all creation, human and non-human as related in a dynamic process. ${ }^{85}$ This analogy is similar to the Indian philosophic tradition of the ancient Sanskrit writing of the Vedas.

"One is to be released by self-power from this abyss of worldly existence. Having resorted to creativity and effort, one is released, just as a lion escapes from his cage." ${ }^{86}$

The holistic analogy is continued by nineteenth century sage, Vivekananda who based his conception of morality on the Vedic ideal that the entire world is your relation (vasudhaiva kutumvakam) ${ }^{87}$ and Sri Aurobindo, who saw the becoming consciousness of the world as a place where human beings, who performed good actions, could promote this process.

"The world is in a great evolutionary process which is not illusory but significant because it is in some sense an evolution traceable to the Divine itself." 88

"Let noble thoughts come to use from all sides...Earth is the mother; I am her son...One must live for one's salvation and for the welfare of the world...Let us make the entire humanity noble and duty-minded....the whole world is one family." 89

Mutual interdependence is where 'hard' mana comes from creation, as it is the tapu (set apartness) of the atua, the creative gods who weaved the world. Collective responsibility means it is binding as well as bonding, so past actions against mana have consequences for the future.

\footnotetext{
${ }^{84}$ Patterson 2000, op.cit 131-133

${ }^{85}$ M Marsden, The Woven Universe: Selected Writings of Rev. Maori Marsden (Masterton: The Estate of Rev. Maori Marsden, 2003), 20.

${ }^{86}$ C Chapple, Karma and Creativity (Albany, State University of New York, 1986), 108.

87 J Shaw 2004, Swami Vivekananda as a Philosopher, op.cit. 17.

${ }^{88} \mathrm{R}$ Minor in Chapple op.cit.15-16.

89 Jha op.cit. 39.
} 
This value has particular relevance for the issue of the compensatory justice of treaty claims that is at the heart of racial misunderstanding. A comparison with the Law of Karma and where it fits in Indian philosophy may be helpful here.

'As you sow, so shall you reap,' is an apt way to describe karma. Actions we take have consequences. Some actions can be righteous and accumulate merit in such responses as positive feedback and increased standing in the community and promote values such as trustworthiness and respect. Other actions can be seen as unrighteous and earn demerits. The Law of Karma could be very helpful in promoting morality and responsibility between Maori and Pakeha worldviews if we free it from any metaphysical requirements.

A way in perhaps is to see that:

".....as you do unselfish moral actions, you realize your dignity as a human being and as you do selfish or immoral actions, you lose your dignity as a human being." 90

This way of balancing human interactions reveals the prescriptive nature of karma as a philosophy. Following its principles encourages the believer to take action to promote harmony between peoples and the world.

Indian Philosophy teaches the operation of the Law of Karma within the concept of Dharma, that which supports the world. Dharmasastra is a code of human conduct.

Dharmasastra also has duties beyond the living and dead to those yet to be born. ${ }^{91}$

The 'universal good' that karma promotes is analogous to the 'knowledge of the Good' envisaged by Plato in the Republic. Plato's view was that the ultimate goal was the 'knowledge of the Good.' The savior of society needed certain values to be realized as the end or goal of life. Plato thought that this 'Good' once known would determine will and action. But he also saw this principle operating throughout Nature, for every living thing had its own 'Good.' Thus knowledge of the 'Good' extends to an understanding of the moral and physical order of the whole universe. ${ }^{92}$

The Law of Karma could be analogous to the Maori concept of utu where utu is a mechanism for restoring lost mana. ${ }^{93}$ The return of a tribal taonga (heirloom or treasure) is one such mechanism.

\footnotetext{
90 Shaw 2000, Man and Freedom, op.cit. 414.

91 Jha 1996, op.cit.2.

92 Nettleship op.cit. Chapter XX111, 206-7.

${ }^{93}$ Patterson 1992, op.cit. 135.
} 
For example the Rongowhakaata tribe has been petitioning the national museum for the return of their tribal meeting house, Te Hau Ki Turanga. The house was taken nearly one hundred years ago and put on exhibition in Wellington.

Patterson says utu was a merit/demerit system where the concepts of mauri (life force), mana (prestige or authority) and tapu (prohibition) operated to balance out kinks in the underlying polarity of the universe. The original offence did not have to be an intentional offence to merit utu. ${ }^{94}$

Karmic residue can still accrue from unintentional acts such as accidents. Although producing a low degree of karma, such acts as hurting a cat could have been avoided if more care had been taken.

"Hence both intention and proper information are considered causal conditions as they affect the doer." ${ }^{95}$

A contemporary example of unintentional offence is people having a picnic in the bush on an unmapped burial site. The common or noa aspect of food is the antithesis of the sacred or tapu nature of death. But some tapu sites are sometimes not marked so that they will not attract desecration from enemies. It is ironic that this practice in rural tribal areas, sometimes invites unintentional desecration. Maori tohunga (ritual experts) are sometimes called in to deal with the sickness or mental illness that has manifested in the people who stumbled on such sites. Karakia (ritual instructions) deal with the utu or karmic residue that needs addressing.

Here the analogy between karma and utu seems to hold up. As a mana restorative mechanism, utu can be reciprocation as acknowledgment, such as the government returning a tract of land to the Ngati Whatua tribe of Auckland. But where mana has been lost through a confiscation of land as in Taranaki, the tribes involved are still seeking utu for the kinship ties with the land that remain broken. ${ }^{96}$

Patterson sees two types of tapu: that of the gods who when offended by insults to their domain take their own retaliation and that involving the mana of us lesser mortals. I see the first tapu operating when a lake or stretch of water is over-fished or when an environment is degraded. Then a period of devastation reigns until a balance is restored in a type of utu. The second tapu involving human beings applies in a collective way to Maori. A slight to the mana of an individual is seen by Maori kinship values as a slight to a family or tribal grouping. In contemporary New Zealand, where Maori culture is practised, the tendency is to see offences as group insults. And where tribal narratives are known, the pain of dispossession is very real especially with daily reminders of other people living on confiscated land. For one such group in Taranaki, the block of land upon which the Cape Egmont lighthouse was built, is their memorial. Confiscated after the 1881 government invasion of Parihaka, a small eighteen acre section of the reserve was leased to one of the Parihaka leaders, Te Whetu Moehau for an annual nominal sum. This lease was continued by his widow after Te Whetu died until the 1940's when Louie Okeroa took over the lease.

\footnotetext{
${ }^{94}$ Ibid. 117, 119.

${ }^{95}$ Shaw 2000, op.cit. 360.

${ }^{96}$ Buchanan op.cit. 184-5.
} 
In 1951 a new lease was negotiated with the Marine Department but Lands and Survey office staff and the Marine Department refused to allow Mrs Okeroa to sign the new lease or to accept her new rent of nine pounds five shillings.

"With the rent unpaid and the lease unsigned, the land was subsequently surveyed and sold to Pakeha farmers." ${ }^{97}$

This action seems strange today on retelling but it is part of the record of the Waitangi Tribunal archives. It is in this way that Patterson's assertion becomes clearer, that utu cannot be forgone and that everyday utu involves restoring the balance of mana of tribal groupings involving recent ancestors. ${ }^{98}$

Thus just as the law of karma is part of the dharma of Indian philosophy encouraging unselfish acts, Maori values can be seen as providing models of behavior that link past and present in an environment similar to a system of 'virtue ethics.' The interplay between utu and mana is an integral part of a Maori philosophy. For common Maori values of hospitality, leadership, bravery, magnanimity, honour in agreements and steadfastness to be displayed, there needs to be an understanding by Pakeha New Zealanders of the concepts and practices of mana, utu and tapu and a willingness to act differently than their ancestors. Many claimants to the Waitangi Tribunal have agreed that the interests of harmony are more important than pursuing full redress for lands and resources taken by previous government legislation. One needs only to inspect the Treasury record of settlement payments and compare with the lodged claim to understand that it is a flexible rather than dogmatic outlook that Maori have taken.

And one need only look to the Maori initiatives in education, such as Kohanga Reo (language preschools) and Wananga (universities) and the Aotearoa Festival of Performing Arts, to see that new ways are replacing old.

For Maori, the direction is to continue the evolutionary path of Maori tradition and adapt old values for contemporary times. A northern kuia called it putting tikanga in new clothes. ${ }^{99}$

In the Dharmasastra of Indian philosophy, the sowing in righteous acts makes recompense for unrighteous deeds but the highest form of karma is that where righteous acts flow from the very nature of the person without any thought of recompense. This concept approaches Patterson's virtue ethics of the rangatira as the apex of Maori ideals. The comparison between Maori and Indian world views is that both valued human effort as defining character virtues. The Mahabharata calls fate nothing but the karmic residue of one's effort.

"Just as a field is sown without seed is barren. So without human effort there is not fate." 100

'Ka pu te ruha, ka hao te rangatahi. The old net is broken, the new net goes fishing.'

(Maori proverb saying that human effort is needed in every new generation)

\footnotetext{
${ }^{97}$ Buchanan ibid. 183-4.

98 Patterson 1992, op.cit. 134.

99 M Szaszy, Seeking the Seeds for the Greatest Good for All People: Maori Graduands Capping Ceremony 28 April 1993 (Wellington, Victoria University \& Huia: 1993), 7.

${ }^{100}$ C Chapple, op.cit. 34, c.f. Shaw 2011, Freedom: East and West, p 4.
} 


\section{Kinship is a value}

Just as righteousness is a value so too is Maori kinship. Kinship identity reaches back and forwards in time. What gives unity to a life with a radically non-individualistic conception of selfhood are the tribal traditions providing historical and social identity. This concept or narrative places the individual along with non-human beings in the cosmos in universal terms (creation myths) and fine detail, such as whakapapa (genealogy) and whanau stories about places and people. The narratives provide a moral education appropriate to virtue-based ethics with exemplars, the imitation of virtuous people. It also provides continuity across time with individuals (identity) and continuity across kinds (humans as kin of the gods, of rivers etc). This is of considerable ethical importance for it defines a moral community of identification and moral growth. ${ }^{102}$

The narrative of universal terms I am talking about such as whakapapa as interconnection and whanaungatanga as primary kinship, could be seen as coming from the widest perspective and fined down in detail to where you live within your whanau. The narrative has been utilised by a French philosopher, as a way of demonstrating how humans describe possibilities in their lives. Humans are said to come already entangled in stories or pre-histories and it is in the choice of narrating or telling our own stories that a personal identity is forged. This telling is called narrative fiction and it is only completed in life. By telling our stories, our life can be understood and in that sense it is an examined life that Socrates claimed was the only life worth living. ${ }^{103}$ To me this means the Greek ideal of reflecting on the purpose of life.

When I reflect on a life described as such, there is a contemporary tension between the traditional Maori conception of self and the modern Western idea of the individual being separate from his or her role. It's like describing society as the effect of people, seemingly existing causa sui (uncaused). Maori values come from seeing life as a shared project where the roles give the context of social relationships in which the virtues function. The unity of the life between generations is strongly enabled in my life by the stories I tell about my whakapapa, my connections to my ancestors, both distant and recent.

Some of my dad's stories were about his days at home in Nuhaka sitting on the back porch looking up at his ancestral mountain of Moumoukai. He also talked of his school life at Te Aute Maori Boys Secondary School in Hawke's Bay. He told us of how the prefects kept a book of merits and demerits of every boy in the school. On Friday the names from the book were read out in the quad and every demerit meant taking a step forward while every merit, a step back. At the end of the reading, those boys at the front got the cane while others got detentions. Dad rarely got the cane so his narrative to us was as one who lived within the rules.

\footnotetext{
102 Patterson 1992, op.cit.110-112, c.f. Whaanga 2008, Maori Ethics (unpublished), Wellington, Victoria University, 2008).

${ }^{103}$ Wood, op. cit. 20-51.
} 
Other stories from dad were of his adult years when he worked for the Maori Affairs Minister in Parliament and shoveled fermented hops from a large bin into trucks, as a form of lunchtime workout. It was meant to be a task unbecoming of a ministerial worker and so kept a secret. But one day the Minister asked for him at lunchtime and was told dad was at the brewery. When dad returned to work the Minister wanted his own brewery tour and proved quite a hit with the workers. Dad said the Minister also received a crate of beer each Christmas as a present! So while my father may have been reliable as a 'company man' he did not always stick within the rules.

Ricoeur's idea of humans coming entangled with pre-histories certainly compares with dad's identity as a tribal descendent of Kahungunu. Dad's great grand-dad, Ihaka Whaanga inherited much land on the Mahia peninsula but by the time it got to dad's dad Kahutia, there was only a two acre homestead and leased farmland for a herd of dairy cows. Dad certainly knew the pre-histories about where and how the land had gone but the narrative he bequeathed to his children was one of Kahutia telling him to leave home and go to the city in search of possibilities. My own narrative has its beginnings in a city but it includes dad's pre-history as whakapapa or interconnection with my tribal roots. The value to me is that dad's story enables me to return to a tribal home at Mahia that I was emotionally born from. As I learn more of my roots I can go further back up the country to where my ancestor Kahungunu journeyed from and so become deeply connected to belonging to this land and cherishing its moods.

There is a connection to the land which could be seen as its moral value, its ability to anchor me in a highly individualistic world of students and tutors where academic worth is judged by people whose values are sometimes foreign to mine. That our tribal land is gone as a result of coercion and the stealth of government policies brings to mind another type of ethics that remains today to be confronted, not just in the Waitangi Tribunal but more importantly in the relationships between New Zealanders. If I have such stories of my tribe and family, then others, Pakeha and Maori, have theirs too. This is the value to me of a philosophy of describing human possibilities as narratives that we might find some commonality from. We can talk with our neighbours about how this land was founded and place ourselves in that story. We are all sojourners in life.

\section{The value of the past}

In a wider Maori philosophical sense, the narrative is also the metaphor embedded in the traditional Maori world view as contained in whakapapa, the description of the phenomenological world in the form of a genealogical recital. Implicit in the meaning of whakapapa are the ideas of orderliness, sequence, evolution and progress. The past conceived of as being in front of (mua) human consciousness, as only past and present are knowable. Muri, meaning behind, is where the future comes from because it cannot be seen. 
Thus the past and present, as a single field of knowledge, means narratives and mythology are constantly referred to embellish the present. ${ }^{104}$ These narratives provide authoritative precedents for correct or tika behavior. ${ }^{105}$ This narrative identity is built on the metaphorical nature of Maori oral tradition which reveals successive layers of meaning as a person becomes more adept. ${ }^{106}$ The narrative tradition of Maori is used to reveal ethical ways of living. ${ }^{107}$

Some narratives are traditional, like the Maui stories which have a common thread of trickery to gain power and knowledge. Maui is a demi-god who tames the sun so that it takes its time crossing the sky thus giving human beings more time in which to work and play. He does this by trapping it with ropes before it rises in the morning and then beating it to make it limp more slowly across the sky. Maui also brings fire to the world of humans by conning the ancestress Mahuika to part with her flaming fingernails. However she catches him out and tries to kill him by using her last fingernail to burn him. This causes the land to catch alight and he calls for rain which saves his life but nearly kills Mahuika. The explanation of this story lies deeper, in that the use of questionable means seems justified by the goal, in Maui's case longer days and fire for humans. Walker's explanation is that deceit and trickery were seen as acceptable if the ends were socially desirable, that of gaining mana. ${ }^{108}$

In Indian philosophy the question is posed - what is the relationship between truth and non-violence? When can a lie be justified? It is said that in the practise of dharma (that which supports the world), everybody is respected. Everyone follows a philosophy of life that is suited to their station of life, as in the practise of dharma, all will lead to the same goal. All choices in life are occasions for the determination of the follower. Non-violence plays an important part in dharma. For example, if by telling the truth, someone will be dishonoured, then the follower may not tell the truth. By the same token, if someone will suffer violence through the telling of the truth, then the truth may not be told. The focus is on restoring the good or the welfare of the whole even if some violence may occur. This is similar to my taking action if I know someone is intent on causing violence. But the caution is that the action must not have selfish motives, it must be not be taken just to save my life. ${ }^{109}$

In the case of Maui and his action to get fire, if the fire was just for him alone it was not justified. But as his actions are representative of his role in looking after the welfare of people, it may be unselfish and so justified in the larger picture.

Before we rush to judgment, remember Patterson's admonition that in Maori myths and proverbs no one story stood on its own, as another story could be used to modify another. The purpose of the narratives was to balance out any disturbance to the life of the tribe and provide examples.

\footnotetext{
${ }^{104}$ R Walker 1996:13 c.f. Whaanga 2009, The nature of bi-cultural beings in Aotearoa or notes about the New Zealanders I live with, (Wellington, unpublished thesis, 2009).

105 Patterson 1992, op.cit. 155.

106 Henare 2010, personal communication.

107 Patterson 1992, op.cit. 182-3.

${ }^{108}$ R Walker, 1978, The Relevance of Maori Myths and Tradition in King M, Tihei Mauri Ora: Aspects of Maoritanga, (New Zealand, Methuen: 1978), 22.

109 J Shaw, Non-Western Philosophy lecture notes, Victoria University, 2007.
} 
The significance of these narratives to worldviews or moral values is that mana can be built up for the collective, such as other Maui stories which involve him searching for his father. He is the youngest of his brothers, the potiki, but overcomes his position by great deeds, such as fishing up the North Island of New Zealand. Thus by using this story as a model, the Maori value towards seniority of kinship is balanced by showing the eldest don't necessarily have to be prominent and that one's mana can be enhanced. Maui's brothers are jealous of him but the eldest counsels acceptance in a proverb, 'I nga ra o te pai hei pai, I nga ra o te kino hei kino - In time of war settle your disputes by force but in time of peace let things be done in a friendly way.' 110 This proverb is just as timely today because a survey of New Zealand values shows that a majority of New Zealanders are not supportive of the settlement of Treaty claims and claim that Maori are not especially disadvantaged. ${ }^{111}$ More will be said about this perception in Chapter Three.

\section{Maori conception of inner form of life}

In pre-Christianity time, tradition says Maori described themselves as descendents of the gods who had mingled with human beings, another way of describing divinity in human beings. The gods and all creation, human and non-human, maintained a balance in this process. The inner life of the human being was the micro tikanga (functioning) that reflected the outer world macro tikanga (functioning).

Tohunga experts, Kereopa and Marsden, who mediated between worlds of knowledge, provide clear explanations of the inner and outer worlds. These are best expressed in the creation myths of the stages of night from first cause (lo), to potential (te Korekore), to becoming (te Po) and being (te Ao Marama). The hero figure Maui may have been a human descendent of the gods but he descended to the goddess of the underworld (Hine-nui Te Po) but was denied rebirth. Perhaps this hinted at man's desire to be eternal like the gods. Tradition says after death, the human spirit returned to Hawaiiki, the ancestral homeland to continue its spiritual existence and one Christian writer said, "People meet up again after death, however it is described "(Hawaiki). ${ }^{112}$

So what does this say about reward or punishment, karma or reincarnation?

In the Maori traditional world there is no re-birth in the sense of an essence of a person taking residence in another human body. However one of the origin narratives talks of Hine-nui Te Po, the goddess of the underworld, waiting to gather her children after death. This suggests a traditional belief in reincarnation. There are also tales of spirits unable to rest in Rarohenga (the underworld) and coming back to have their spirits placated. This is the balancing interplay between mana, tapu and utu that Patterson talks about and the collective worldview of the Maori. ${ }^{113}$

\footnotetext{
${ }^{110}$ G Grey 1971, Nga Mahi a Nga Tupuna, in A Alpers Maori Myths and Tribal Legends (Auckland, Longman Paul: 1964), 31.

${ }^{111}$ H Gold \& A Webster 1990, op.cit. xvi.

${ }^{112}$ Cody 2004 op.cit. 43. Cody makes this point in stressing the difference between Maori belief and Christianity. Because Maori had no concept of original sin ('fall'), they had little need for a personal savior, of Jesus (ibid, 98.)

113 Patterson 1992, op.cit. 116-135.
} 
In this life, the individual finds his or her expression in living in and for the collective and so the reward or punishment of an individual who dies carries on in the degree of mana that is displayed in the tribe.

Mana was a collective prestige or authority expressed tribally through kinship ties of ancestor groupings, but mana ultimately came from the gods. Lost mana amongst humans was a matter for collective redress against the offenders expressed as utu or restoring the balance. However when the gods are the offended party, they swiftly and inevitably act. After all, the proverb says that tapu is the mana of the gods. ${ }^{114}$ As we saw earlier in our discussion, transgressions of mana had consequences for the future, and utu was a human mechanism for restoring lost mana. Now coupled with that, we find the law of tapu could operate without human intervention when the gods are the offended party. Keeping in mind the Maori tradition of humans having godly ancestors, the interplay of mana, tapu and utu seems comparable to a description of karma as a moral thread to link past actions with present circumstances and future possibilities. As you sow, so shall you reap. ${ }^{115}$ So I believe the law of karma did apply to Maori philosophy. Tohunga and clergyman, Maori Marsden said the ultimate reality was lo and was expressed in the cosmic reconciling of all. Maori language reflects this as a continuous sequence in past, present or future tenses, "e..........ana." 116

This continuous sequence is of importance to any discussion of values, because as we have seen with a philosophy of ideals as a virtue philosophy, the models for one's actions are typically found in the past.

As a tribe will have traditions of the illustrious deeds of their ancestors when their mana was great, the aspirations of the tribe are to restore this mana. So it could be said that the goals for traditional Maori were rooted in the past. This is unlike a typical Pakeha Aristotelean response, which values looking ahead to the future for goals and aspirations. But mana can also be seen as relative, assessed independently by parties as to what their situation of standing is. Thus thinking of utu in terms of restoring the lost mana doesn't really do the concept justice. Rather a dynamic balance is aimed for where more than 'an eye for an eye' is needed. Lavish hospitality is sought to repay hospitality because mana goes to the giver not the recipient. ${ }^{117}$

To think of utu as replacing the loss of mana is also off the mark. Mana is not thought of as a substance that is parceled out but more as something of a reputation that can be earned through righteous action or discredited by unrighteous action. In this way mana manifests as the law of karma. This concept of mana as both a warlike and peaceful action is a very useful explanation to bear in mind when we discuss the interaction of Maori and Pakeha values in Chapter Two and Three. It also is a useful frame to put into context the long time pursuit of tribal treaty claims that puzzles some Pakeha New Zealanders. Thus it can be seen that what can appear to the non-Maori eye as litigious protest action over resource depletion is more likely to entail unfamiliar concepts, such as mana, not easily understood by observers.

\footnotetext{
114 Jackson 1988, op.cit. 43.

115 J Shaw 2008, lecture notes Phil 308 Non-Western Philosophy, Victoria University, Wellington

${ }^{116}$ Marsden, op.cit. 20, c.f. Whaanga 2009 op.cit.

${ }^{117}$ Patterson 1992, op.cit. 122-123.
} 
It is like having tribal land or waters taken from your ancestors by force and then having to watch others strip the resources by over-farming (Gisborne area and Cyclone Bola) or over-fishing (Lake Rotorua). Maori values promote living in harmony with the land and sea because if I am good to my kin (the environment), it will in turn be good to me. In the context of needing to harmonise Maori and Pakeha values, it could be that if you do something good e.g. don't overfish our resources, I can do more for you in return e.g. invite you to my birthday hangi (underground steam oven) of cooked fish. And so the law of karma is retained.

“.... culture's classification schema is likely to be related to its values, to its conceptions of acceptable and unacceptable behavior, to its ideas of laudable and undesirable character traits, to its prescriptions relating to virtues and vices." ${ }^{118}$

\section{Divinity in the world}

If tapu is the mana of the gods, then could tradition be employed to advocate for the concept of a shared divinity with humans that might lead to common values? A Maori parenting model is now being promoted that relies on this pre-European tradition where children were seen as spiritual beings to be treated with loving care and indulgence. But it has been criticized for being unrealistic. However the director says the point was to find a picture of parenting values and adapt them to contemporary society. ${ }^{119}$

The Maori world of metaphor is similar to that of the Greeks and the use that Plato made of a metaphorical Heaven where Ideas dwelt as universals and were reflected as particulars in this world. Thus human beings were a reflection of divinity. This was how he taught abstract thought to simple people. In effect, Platonic thought was also defining what existence was. Although the 'it' of existence could not be tied down, Plato taught of 'form' being imposed on 'matter' and this has continued as a bedrock explanation in Western philosophy. Human beings gained knowledge by rationally discovering 'things' in the world. A major proof of divinity by St Anselm in the twelfth century, built on this Platonic reasoning by arguing that the existence of God could be proved by thinking of the concept of a perfect being that had no beginning and no end. Another Christian monk, Gaunilo rebutted this argument saying we can think of many perfect things, even of their non-existence, but that understanding needs a reality check as proof. Echoing Aristotelean thought, Gaunilo said the actuality of existence doesn't follow from the potentiality of the Idea of existence. It is not an ontological argument of 'being.' Anselm countered this argument by saying the concept of God as omnipotent is not contingent: such as having a beginning or end or being composed of parts. God is also not like an imagined being in space and time because God was either all pervasive or not at all temporal in space or time. Thinking of God's existence is not the same as thinking of non-existence. Therefore God's existence is necessary. This was a Christian argument for divinity.

\footnotetext{
118 Patterson ibid, 98.

${ }^{119}$ Dominion Post 2011, June 4, A19.
} 
I claim Anselm's argument was following Plato's concept of Ideas being in Heaven and that Gaunilo's counter, used Aristotle's more practical philosophy of bringing existence into this world in actuality where humans can compare and learn values to live by. ${ }^{120}$ Just as Platonic Idealism was unhelpful as a concept of divinity that stayed in Heaven, it also didn't help Aristotle explain how things changed in the world, for example how an acorn turned into an oak tree. So Aristotle brought Plato's Ideas into the world as Form and Essence that had Potentiality to act in Matter. Thus the acorn has the Potentiality of the oak tree within the seed and the oak tree as material Matter, manifests this as Actuality. So an analogy could be drawn that Aristotle's argument about potentiality is saying that human beings are potentially divine.

A comparison of these points with Maori concepts is difficult. Patterson says there is little evidence of commitment to metaphysical realism amongst the Maori, whereas Pakeha writers posit some real entity to correspond with each term of the language. ${ }^{121}$ Also my interpretation of Maori philosophy is not so centered on causality as on value judgments. My point is not to argue the finer points of cosmology but rather to draw out the potentially divine characteristics of humans and the actions that can flow from this attitude.

Patterson puts it:

"Pakeha should try to leave behind their often overriding interests in how things came into being and how they came to be as they are, replacing it with another sort of interest, an interest in the value relations between the parts of the universe rather than the causal relations, an interest in what matters rather than what happens. The narratives can carry value judgments that are easily overlooked." 122

\footnotetext{
${ }^{120}$ Of course both twelfth century monks were scholars of a Christian tradition that had fused Greek theology with Judaic wisdom through the teachings of Jesus' contemporary, Paul of Tarsus.

${ }^{121}$ Patterson 1992, op.cit. 162.

122 Patterson, ibid, 156.
} 
The Maori narrative I offer to compare with Aristotle's explanation of change, is the nights of creation offered by tohunga Marsden as a narrative of the Sky father and Earth mother clinging together and begetting children between them. Patterson backs this view, that evolutionary development, as a Maori concept, is followed by fertilization where ethically important connections are depicted as whakapapa or genealogical relations.

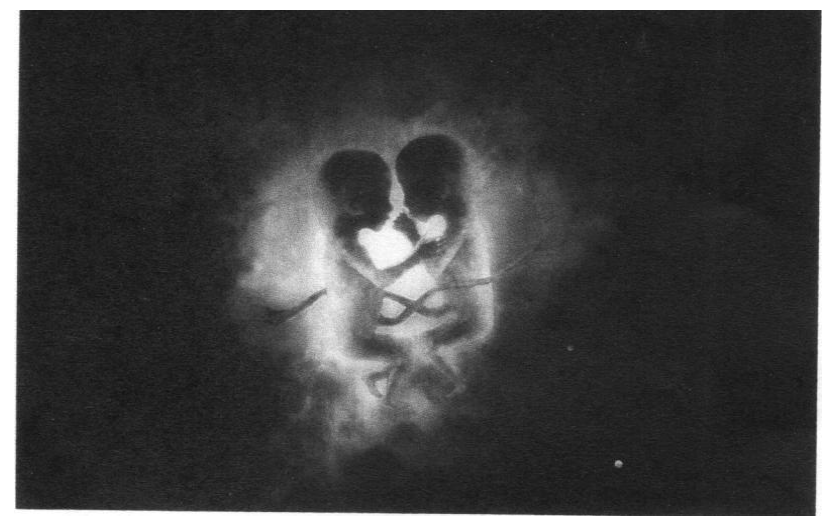

Sky father and Earth mother locked in an embryonic embrace. (Illustration from Tatai Arorangi: Maori Astronomy, Work of the Gods)

A tradition from the Matorohanga manuscripts of the East Coast tribes describes the creation relationship as three nesting spheres. The human world is surrounded by Te Ao Marama (the world of light). Te Po encloses this world and has two realms, Nga Rangi Ngahuru (gods and their children) and Te Po Rarohenga (gods of the underworld.) Te Po is in turn enclosed by Te Kore (the void of potentiality) where Ranginui (Sky father) and Papatuanuku (Earth mother) were created. ${ }^{123}$

The Maori conception of nesting spheres expresses how the potential became actual.

So we are the children of Ranginui and Papatuanuku and as such have certain obligations, such as loving affection and responsibility to care for our kin the forests and mountains, seas and fishes, animals and birds.

\footnotetext{
${ }^{123}$ K Leather \& R Hall, Tatai Arorangi: Maori Astronomy, Work of the Gods, (Paraparaumu, Viking Sevenseas NZ Ltd: 2004), 17.
} 
This is quite a contrast with the Semitic traditions that most Pakeha follow, where the creator god is far removed and more interested in obedience. The divine offspring, in the Semitic tradition, begin their life by being tested and found wanting. They are then tossed out of their cozy environment and have to earn their bread through hard work. There is no partiality. The human relationship with the environment is now one of domination that continues today through the Pakeha settler philosophies that enabled colonization. ${ }^{124}$

\section{Divine sharing}

As far as a concept of shared divinity leading to some commonality in human values, the philosophy behind the Maori nights of creation as explained by Marsden, can be compared favourably with the Greek fathers of philosophy. Plato taught that the 'Good' was the true end of life and Aristotle advanced this as a theory of causation. The Formal cause is the 'essence' and the Final cause is the 'realization' of the potentiality of the 'Good of a thing.' Human beings exist because they exhibit purpose and they change. The Maori counterpoint of purpose is the mauri that unites all creation. Maori creation evolves from a void (potential), a series of long nights (becoming) and 'being' in the world of knowing (Te Ao Marama). Similar to Platonic thought, a Maori worldview sees purpose or reason in nature also, not just in the human realm. This purpose is to reveal human kinship with all of creation, animate and inanimate and so realise the ultimate harmony between nature and human beings.

For Plato the 'Good' is ontologically equated with its 'being' as an activity. ${ }^{125}$ And similar to Plato's philosophy of Good, the human personal relationship for Maori is expressed philosophically through lo Matua Kore -the parentless one or uncaused. ${ }^{126}$ The impersonal connection is lived trying to realize the 'Good' as a value ethic similar to Patterson's concept of 'environmental kinship.' If we take a traditional Maori stance and see humans in Aotearoa as children of Tane, this requires that we take care of the forests and all creatures on the land so that this world continues. But this care takes more than a having a nice feeling about nature, it means as top of the food-chain, taking responsibility and love, sharing our hearts. Our mana depends on it: if we take responsibility we retain or even gain mana. ${ }^{127}$

To me it appears as though the impersonal nature of realizing the Good in a connected natural environment is not quite the same as equating to the concept of God as the most perfect being (St Anselm). Put simply, a Maori view involves balancing polar opposites exemplified in the story of Rata and the forest guardians. Rata needs to build a canoe to travel and avenge the death of his father. He goes into the forest and after some time manages to fell a giant totara. But in his haste he has forgotten to offer a karakia as ritual permission from Tane. So after he goes home, the forest creatures restore the totara to an upright position. This goes on for some days until Rata hides and discovers what is going on. He then realizes he needs to first ask permission.

\footnotetext{
124 Patterson 2000, op.cit.78.

${ }^{125}$ At times Plato used the terms Good and God interchangeably. Good was impersonal and God personal.

${ }^{126}$ Marsden 2003, op.cit.20.

127 Patterson 2000 op.cit. 116-117.
} 
The story has a happy ending but the value judgment is that man has a place in the natural world but all creatures need to be respected, all interests must be weighed up before appropriation. ${ }^{128}$

But where Maori values stress balancing concepts such as light and dark, death and life, a Pakeha view more often stresses that good must drive out evil. In this way, God as the most perfect being of St Anselm resembles the perfect Pakeha world containing only the Good. In the next chapter we will see that it was over this point that Christian values clashed most with Maori values.

But the whakapapa connection of lo Matua Kore to the world of knowing (Te Ao Marama) and on to the changing world (Te Ao Hurihuri) is one based on relationship and interconnection. Humans are in this world together with non-humans and all rise or all fall together. Out of conflict comes awareness that something else is needed along with a striving to make progress. A Maori way of seeing it is that because of our human origins, there is a kinship or understanding with the natural world needed to stand in this land. Patterson makes the point that the European scientific bent leans to the impersonal and mechanical but the Maori view is that the order of the universe is also an ethical order. The relationships with various living creatures implies responsibilities. Ecologist, Goldsmith says humans come to find what is of value in the world through a proper understanding of natural environments. ${ }^{129}$

When we as humans value the ethical order of the world through Maori philosophy and take responsibility for our part in maintaining the tikanga or functioning, then we are cooperating with what could be seen as Plato's ultimate goal, the knowledge of the Good. This is not just theory but also the realization of this value.

"For the savior of society the one thing needful is a certain and immediate knowledge of values, the ends of which all life, private or public, should realize." ${ }^{130}$

It is here in these comparable examples from Greek and twelfth century European philosophy that I would claim Maori philosophy reveals a world view that Pakeha may come to understand and appreciate.

\section{Evolutionary ethics}

So how to build on ethical values for the good? One epistemology of Maori knowledge provides a contemporary setting. Here Maori beliefs and practices are seen as providing traces of traditional culture. Henare says life is experienced as culture and culture is the religion, not a sacred book of dogma. Also traditional Maori culture is prescriptive and open to evaluation and questioning in order to seek that which is 'tika' (functional). ${ }^{131}$

\footnotetext{
${ }^{128}$ Patterson 1992, op.cit. 183.

${ }^{129}$ Goldsmith 1996, 170 in Patterson 2000, op.cit. 30.

${ }^{130} \mathrm{R}$ L Nettleship, Lectures on the Republic of Plato (London, MacMillan and Co: 1897), 206.

${ }^{131} \mathrm{~V}$ Tapine, Building Research Capacity within Maori Communities, Proceedings of a wananga 12 July 1999 (Wellington, NZ Council for Educational Research, 2000), 8.
} 
However my years experienced as a young adult during the Maori renaissance in the 1970's through the first ten years of the new millennium suggest there has been a tendency for a dogmatic standardization of Maori 'tradition' that has had the effect of 'freezing' rituals and making them unchallengeable.

Such a case is women's speaking 'rights' in front of the meeting house on the marae in the formal speeches of welcome. The association with 'rights' is more a link to civil rights for individuals and groups than with Maori protocols. What looks like a prohibition from a Pakeha perspective is a Maori tradition that stemmed from protecting women as the tribal child-bearers (whare tangata) from the mahi whaiwhaia (spells) of other tribes-people. Thus male warriors and orators shielded their women when approaching another tribal group by showing aroha and kaitiakitanga (concern and protection) to their own whilst demonstrating rangatiratanga (leadership) to the strangers. What could be seen as gender inequality are cultural security procedures probably developed around the need to swap food resources with Maori outside of the extended whanau area. It operated as a survival mechanism when tribes like that of Te Rauparaha in the Kawhia area (Raglan), were faced with competition for resources. People had to leave familiar faces and take on the unknown. Establishing protocols for interaction was necessary to avoid unnecessary bloodshed.

And as Maori culture is practised as a minority culture in Aotearoa/New Zealand, it is usually the majority culture overview that explains Maori values for both the context and intent. The 2007 police raids on the Tuhoe people in the Urewera is an example of this relationship. The spectre of Maori terrorists remains in the public mind even though the police actions were found by the court to be illegal. ${ }^{132}$ This situation of imbalance is that of all minority cultures which exist on the fringe of the majority and is a further reason for New Zealanders to cultivate an attitude of desiring common values.

But the feature that Henare stresses is that Maori culture is not frozen, that it has an evolutionary ethic that responds to changing contexts and environments. Evolutionary ethics is a body of theory which seeks to locate moral institutions within the main ideas of evolutionary biology. The general thesis is that we value things and persons in accordance with the capacity to sustain and maintain survival in evolutionary terms i.e. friendship and altruism preserve human beings against violence and hostile environments. ${ }^{133}$ Applying this to Maori culture, a philosophy of adapting tikanga (as functioning) for survival, means an evaluation is always being made when and where Maori practise their culture. It is a holistic balance where the tikanga (function) needs to seen in context, not in isolation. ${ }^{134}$ In my example of women speaking before the meeting house, there is a complementary function (tikanga) for women, which is to open the speech exchange with the karanga (call). This is vital to recognizing the mauri of the occasion. It establishes the mana of the visitors and the hosts by stating whakapapa (tribal) connections between the two groups; mourns bereaved ones; and states the purpose of the visit.

Let us now reflect on this aspect of evolutionary ethics through a comparative analogy in Indian philosophy.

132 Operation 8, Maori Television documentary on Urewera police raids screened October 30, 2011. Police charges were dropped for all but four who were found guilty of charges related to possession of firearms.

${ }^{133}$ Ruse 1979 c.f. Dictionary of Philosophy: 256.

${ }^{134}$ Patterson 1992, op.cit. 38. 
Dharmasastra incorporates this evolutionary ethic in making provision for changing circumstances in society, otherwise it would not invite the obedience of the citizens. Dharma, interpreted as a sense of nourishing or retaining, has a more refined form in the Vedic term Rta, which means a course or cycle, indicating the law of karma. The entities Mitra and Varuna exercise lordship over the universe because of Rta. The Indian writer, Sastri says the uses of the term Rta in the Rgveda are authoritative as this is the oldest source of knowledge of Aryan culture. He says in this Vedic explanation, Rta represents the moral aspect and Dharma the spiritual aspect. ${ }^{135}$ In other words, evolutionary ethics are dynamic.

The Book of Manu says dharma as a moral code is not fixed for all time but must be learned in each generation from what is observed or allowed by learned men who are good and ever free from hatred and inordinate affection. ${ }^{136}$

In the Maori world, maintaining tika is the means by which ethics and values can be identified. Henare's model is a 'koru of Maori ethics:' lo/Tapu as sacredness of wairua (the human spirit); Mana as the respectful authority towards the mauri - the life force of all; and Hau as the spirit transported by gift. Tika (correctness) operates to give connection to the spiritual realm which recognises the sacredness and vitality of all creation, beings and environment. This then passes to the significance of reciprocity in human relations. Henare sees these relations as expressing:

Whanaungatanga - belonging as identity;

The concept of whanaungatanga comes from the root meaning of whanau which is to give birth. ${ }^{137}$ The addition of tanga makes it a noun, thus 'birthing.' A baby is seen as being born with the combination of both parents' tribes and this in turn goes back to the grandparents and so on. If this genealogy is known and taught along with the prominent ancestors and their feats, then the connections allow the person to whakapapa or figuratively 'spread themselves over the land.' The whakapapa thus becomes an identity where the person has a sense of belonging. A person who has a skill in oratory can embellish their connections with traditional tribal pepeha (sayings) and moteatea (chants) and so show where and how they belong in any Maori gathering. Such a person who knows their whakapapa can link themselves through their tribes and unify the people at a gathering simply by demonstrating oneness in their origins.

Other relations Henare sees are:

Wairuatanga as the connection of all;

Kotahitanga as unity/one-ness with tapu and mauri;

Kaitiakitanga as the guardianship of all resources.

So sacred could be seen to be equivalent to the life force of all, or the good of all.

\footnotetext{
135 Jha 1996, op.cit. 5-18.

${ }^{136}$ Manu 11.1.in G Buhler, The Laws of Manu (Sacred Books of the East, XXV, Oxford, 1886)

${ }^{137}$ A Reed, Reed Concise Maori Dictionary (Wellington, Reed, 1949), 100.
} 
These philosophic principles operated by being practised and so created a world of enlightenment Te Ao Marama. This evolved into Te Ao Hurihuri, the changing world. ${ }^{138}$

\section{How do humans move from philosophic principles to knowing this world?}

Comparisons can be made between this Maori view and with Plato's conception of eternal and unchanging entities. The soul living in the realm of Ideas (Heaven) and reflections of these Ideas in this world, can be apprehended by humans because the human soul remembers. Plato's contribution was to formulate concepts as human constructs in the mind, what is termed objectivity. The British logician, Alfred Whitehead, who lived from 1861-1947 said "...the safest general characterization of the European philosophical tradition is that is a series of footnotes to Plato." 139

Plato's student, Aristotle, advanced this thinking by postulating that the Ideas and Reflections are synthesized in this world and humanity can be found in human beings, as justice can be found in just actions. This principle of universals (humanity, justice) being found in particulars (human beings, just actions) was used to explain how we can 'know' - which is the fundamental building block of humanity. Understanding the process of how human beings come to know is a recipe for cultural harmony because it is misunderstanding the cultural ways of knowing that produces disharmony. At the end of the day, what is common in the culture of all people is that we are all human beings. In Maori culture this humanity is expressed by being practised, it is a prescriptive philosophy. By actioning our philosophy and fulfilling the prescription, we realize the intention through our lives.

The foregoing Maori philosophy is not so much a description of Maori cosmology but a prescription of the way it works, a 'how-to' guide rather than a 'what is.' Valuing what matters rather than what happens. And what matters is the value we place on the relationships in the creation narratives of Rangi (Sky father) and Papa (Earth mother) and the feats of their children in fashioning the world. One account tells of the forming of the first human, Hine Ahu One (woman from heaped up earth) by one of the children, Tane and his subsequent union with her. It is through this union that humans are descended. Rangimarie Rose Pere says the connection is both physical and spiritual as humans have evolved from the materials of the planet Earth but ".... Maori see the Earth as their mother, someone who nutures us and to whom in turn we owe important duties of care." 140

Indian philosophy too emphasizes connection with the Earth.

\footnotetext{
138 Henare 1998 c.f. in Tapine, op.cit. 8.

${ }^{139}$ A Whitehead, D Griffin \& D Sherburne (eds.) Process and Reality -an essay in cosmology, (New York, Free Press, 1979), 37.

140 Patterson 1992, op.cit. 156-157.
} 
'Earth is the mother; I am her son,' 'One must live for one's salvation and for the welfare of the world,' 'The whole world is one family.' ${ }^{141}$

Penetito says the ethics of Maori philosophy led to an economy of affection and utilization of resources to enable Maori to live in kinship systems, a concept that is a key part of environmental philosophy. ${ }^{142}$ Penetito believes some Pakeha knowledge cohered with Maori knowledge and both Marsden ${ }^{143}$ and Kereopa ${ }^{144}$ believed and practised the accommodation of Pakeha religion into their Maori world. So much so, that Kereopa cites the Tuhoe prophet, Rua Kenana, as allotting administrative duties to Methodist clergy and retaining ritual roles for Ringatu ministers. Also Maori Marsden was an official Anglican priest while retaining his role as tohunga or Maori healer as well as lo practitioner. ${ }^{145}$

A Western view of religion is hard to equate with the way of pre-contact Maori if religion is seen as a set of unchanging dogma. This pre-contact Maori philosophy is culture as a way of living for the betterment of all, human and non-human. The example given earlier about women not speaking on ritual occasions before a meeting house on the marae is because of this concept of betterment. In this case, men and women have complementary speaking functions on ritual occasions for the betterment of Maori people as a unity. Another example of what we ought to do for the betterment of all comes from an area of the Kapiti coast where I have a beach home. Periodically new immigrants come and collect crabs and pipi. Most times they come in numbers and fill large plastic containers and run fishing lines with many hooks baited for crabs. I usually ask them not to over-fish the area or continue to take under-size pipi. This way I say our generation can make sure there will be plenty of kaimoana (seafood) for our grandchildren and that will be for the 'good of all.'

Some Pakeha descriptions call this pre-contact Maori philosophy 'animist' as in the veneration of features of the environment. Other commentators are much influenced by Judeo Christian philosophy and see in Maori beliefs, a hierarchy of deities and a supreme God. My view is this.

lo Matua Kore (the parentless one or uncaused one) and Ranginui (Sky father) and Papatuanuku (Earth mother) begat sons who tried to separate the embrace of their parents which was the dark world into which they were born. Tane alone succeeded, by putting his back against his mother and placing his feet against his father and thus pushing the sky into its present position above the earth. While his act brings light and knowledge into the world, it is also an act of cruelty against his parents and that is why his brother Tawhirimatea seeks utu or recompense by attacking Tane with a wind storm. Looking at this narrative as a value account, I can draw a precedent for human parenting. Children need to break from their parents and while this can bring grief, it is needed for growth to take place.

\footnotetext{
${ }^{141}$ D Shanbhag in History of Philosophy Eastern and Western Volume One (London, Allen \& Unwin; 1952$), 39$.

${ }^{142}$ W Penetito, Tree of Opportunity - rethinking Pacific education, (Fiji, University of South Pacific: 2002), 130.

143 Marsden 2003, op. cit.

${ }^{144}$ P Moon, Tohunga Hohepa Kereopa,(Auckland, David Ling Publishing Limited; 2003)

${ }^{145}$ P Cody, Seeds of The Word, (Wellington, Steele Roberts Ltd., 2004), 56.
} 
And it is this growth in children that brings about the separation. ${ }^{146}$ Other brothers were Tu Matauenga, Tangaroa, Whiro and Rongo. The second female deity after the Earth mother, became Hine Ahu One after being formed by Tane out of earth. She bore Tane a daughter, Hine Titama who grew up to be beautiful. In time Hine Titama bore several daughters to Tane but when she learned her husband was also her father, she fled to the underworld. Here she takes refuge with her grandmother, Papatuanuku.

This can be seen as another value precedent, that of special responsibilities which grandparents have towards mokopuna (grandchildren), especially where there has been mistreatment. Tane is told to stay behind in the world to look after the children and Hine Titama waits in the underworld to gather them in. She changes her name to signify her new status, Hine-nui-Te-Po (Hine of the big night). So it can be seen that while there is causality in this short account of creation, what matters is the value relations between the deities, the mother and father. It is not so much hierarchical as relational.

There is a direct correlation between a philosophical concept of an afterlife, hinted at in this traditional narrative of Hine Titama awaiting her children, and the accounts of some Maori mental health professionals. Psychologist Donna Awatere says it is not uncommon for Maori to be visited by ancestors during their waking hours. Traditional Maori believed the dead came back because they could not rest in Rarohenga (the underworld) and something needed to be attended to, to placate their spirit. But Awatere says Maori were normally locked away and given sedatives when they told Pakeha doctors and nurses of these visions. And language pioneer, Katarina Mataira said Maori mental health was dependent on a functioning relationship between the wairua (spiritual mauri or essence) of a person, their hinengaro (mental faculties), their tinana (body) and their whanau (extended family). The value of the philosophical concept of whanaungatanga as belonging within a supportive framework of relationships, has immense benefits for harmony within a person as well as within communities of people. $^{147}$

Traditionalists like Rangimarie Pere speak of relationship when they say AIO or IO was the supreme God, the name being formed from the vibration of the Maori language sounds of $A$ symbolising mother, $O$ symbolizing father and I symbolizing child. Pere says "he reo huna te reo Maori," that Maori language is used to communicate abstraction, the $I$ of the child symbolizing the inner universe that can be seen as the divine spark. ${ }^{148} \mathrm{Her}$ interpretation resounds with one view in Indian philosophy that sees humanity as reflections of the divine spark. Just as seeing the moon reflected in a pool does not detract from its ability or identity in the night sky, so humans could see themselves as sparks from one big parent fire. ${ }^{149}$

\footnotetext{
${ }^{146}$ Patterson 1992, op.cit. 158.

147 Maori Television, programme on Wairua screened July 22, 2011.

148 Tapine, op.cit. 27-28.

${ }^{149}$ Shaw 2008 lecture notes
} 
A further Indian comparator of Pere's language metaphor comes from the sabdadvaita (word monistic) school of the Grammarians, who say language is the ultimate reality and this does not refer to any particular language. ${ }^{150}$

This lo was claimed by the early missionaries as a sign that Maori were favoured and so worthy of the new knowledge of the supreme God's son Jesus, which Christianity brought. Some contemporary writers have claimed that lo is a reconstruction of post-contact Maori that reifies Maori philosophy and they take their lead from the critique of Maori anthropologist, Peter Buck. He believed lo talk was inspired by the Christian god but Buck later changed his mind. ${ }^{151}$ Some, like Cody say it validates an authentic conversion belief that brings Maori and Pakeha believers together. But Cruickshank goes further, saying that lo is pre-contact vindication of biblical truths that one God was revealed in national cultures. ${ }^{152}$

Whatever the reasons, the acknowledgment by Pakeha of different names for an ultimate god and the diversity of Maori gods and goddesses is a good sign. The prominence of female goddesses may also be a point of commonality between Maori philosophy and a Pakeha feminist viewpoint. Cody also supports a pre-contact knowledge of lo but for slightly different reasons. He says whatever the origins, lo's different names indicate an underlying purpose and meaning to life, from lo-kore te whiwhia (unchanging) to lo-pukenga (lo the first cause).

He quotes Marsden as saying the essence of lo flowed forth to fertilize Te Korekore (the void). lo gives meaning to everything and allots work to each creature. ${ }^{153}$ This action can be compared to the Good of Plato. Nettleship says in Greek 'the Good' was synonymous with 'Goodness itself.'

"The knowledge of the Good, on which well-being depends, is now to include an understanding of the moral and physical order of the whole universe."154

The 'Good' that is being talked about by Plato is not that which is in contemporary use when we say someone is a 'good person.' There is no ordinary moral association. Rather to the Greeks, Good meant,

"....the object of desire, that which is most worth having, that which we most want."

The 'Good' varies for a human each day but Greek philosophy thought that a human lives for something and that is seen as having a 'Good' to aim at as an end. Nettleship believed it was another way of saying humans are rational, that we are creatures of means and ends. Greek philosophy uses words like rational and reason where contemporary words to express the same would be spirit, spiritual or ideals.

\footnotetext{
${ }^{150}$ Bhartrhari (570 C.E. - 651) Hindu philosopher and poet-grammarian, author of 'Vakyapdiya' (Words in a Sentence) regarded as one of the most significant works on the philosophy of language.

${ }^{151}$ M Henare, 2003, op.cit. 71.

152 Cruickshank, Io Origins Te Matauranga o te Ao Kohatu, He taonga tuku iho mai a lo ki te Ao Hurihuri, Ancient knowledge of the Living God in Aotearoa (Whangarei, Graham Cruickshank, 1998) 8.

${ }^{153}$ Cody 2004, op.cit. 54-55.

154 Nettleship op.cit. 206
} 
Plato used the word 'Good' to mean anything which is meant to do or to be, based on the hypothesis that:

"... there is reason operating in the world, in man and in nature...a certain principle that correlates ...in the light of which alone they can be understood..." 155

Thus Plato's 'Good' can be favourably compared to Marsden's concept of the unity of lo as giving meaning to all life.

Cody sees this action of Io, as providing a 'seed of the Word of God.' In other words - the potential for releasing the divinity in all creation. This concept is explained in Chapter Two, as a settler value present in Christianity.

\section{Place of tradition}

So how did these pre-Pakeha contact values live on. Well, stories were told and depictions made where humans were placed in perspective. These included whakapapa (genealogical recitals); moteatea (chants); carvings; weavings; ornaments; installations and various interactions with the natural environment. Tohunga (ritual experts) Hohepa Kereopa and Marsden used oral tradition or verbal testimony, as Indian philosophy terms it.

Maori oral tradition can be compared with the verbal testimony of Indian philosophic systems. Poems and songs of the Vedas first captured the beginnings of Indian philosophy in the period $2500-600$ B.C. In the Epic Period (600 B.C. - 200 A.D.) the indirect presentation of philosophical doctrines was captured in the great stories of Ramayana and Mahabharata. It was also the time of orthodoxy where Buddhism, Jainism, Hinduism and Carvaka were developed. Six Hindu systems followed on from the early centuries of the Christian era. These systems were the Nyaya, the Vaisesika, the Samkhya, the Yoga, the Purva Mimamsa and Vedanta. In this later period of the Sutras, the previously constructive imagination and spontaneous insights were systematized as self-conscious thought and reflection. ${ }^{156}$ According to these systems, oral tradition depends on the utterance of the person who knows it to be true and when the person conveys it, does so without distorting it. Therefore oral tradition is rational depending on the person and is not dependent on a supernatural being. Indian philosophy says verbal testimony is one of the sources of knowledge. Testimony means a person who narrates it, knows it - so rationality is not relevant because no reason is involved. It can be expressed as $X$ has seen it and depending on the truthfulness of $X, Y$ can get the knowledge.

The following Maori traditional lament is an oral utterance, a narrative learned to aid the pursuit of knowledge and the values expressed through the lament. It is not knowledge in that it is saying anything new about star formations but it is prescriptive for showing an attitude of respect to elders through reference to the stars. This respectful attitude is a value that will lead to increased understanding.

\footnotetext{
155 Ibid, 218-225.

${ }^{156}$ S Radhakrishnan \& C Moore (eds.) A Source Book in Indian Philosophy (London, Allen \& Unwin: 1967), xix, xx.
} 
Tera te whetu e, kapohia ana mai, ka rumaki Matariki, ka rere Tawera,

Kapohia, e hine, te atarau o te rangi, kapua whakatu i runga o Tapuae,

To tupuna ra e, e moe whakarunga.

There is the star flashing, Matariki has set, Tawera is high

O girl, the lights of the heavens are flashing, clouds are standing on Tapuae,

Your ancestor there, sleeping in the heavens.

This is the beginning of a lament by Nawemata of Ngapuhi for her husband, killed at Ruapekapeka $1845 .{ }^{157}$

Knowledge of the ancients' world was used to order their lives, in particular matai whetu, study of the stars. Ethnologist, David Simmons says the information was arranged in whakapapa and recitation of star names was known as tatai whetu and navigation across the seas known as tatai aro rangi, finding the appropriate path by the stars. He says colonisation and a new religion resulted in much knowledge being lost to view but the elders were wise and incorporated the information in song and stories. Those wishing to access the knowledge must respect the elders and not diminish their mana or that of their descendants. ${ }^{158}$ This attitude of respect for elders may help Pakeha understand why it is a value that can bring harmony towards Maori.

Following Patterson's injunction to look behind the Maori narrative for what is being said about values, we can gainfully examine a story about the search for knowledge, Tane and the Baskets of Knowledge. One account is that lo, the supreme god sends for Tane to ascend to the heavens and retrieve three baskets of knowledge. Smith says wananga is the term used for baskets of knowledge which contained in turn: knowledge of peace, goodness and love; knowledge of karakia and ritual; and knowledge of warfare, agriculture and crafts. A correlation between the baskets is the order in which they are presented, knowledge of peace being rated higher than karakia and ritual and knowledge of warfare coming last.

Thus knowledge is seen to be from the gods and inherits some of their tapu. So it demands respect and should not be meddled with by ordinary folk. There is a feeling of reverence. This is unlike a Pakeha view that sees no topic of knowledge as being immune to scrutiny. This appears to some Maori as an attitude of disrespect. It can be compared to the practice of taking one's shoes off when coming into a person's home. If that is the practice of the home, then guests show respect by doing so. It could be justified on scientific grounds of hygiene but it also has a Maori value of relationship, one of respecting another's beliefs when you are invited into their home. In a larger context, Aotearoa/New Zealand is the only home of Maori and a remedy for harmony is for Pakeha to respect they are sharing a Maori home.

${ }^{157}$ Leather \& Hall, op.cit. 4.

${ }^{158}$ G Grey 1853, Nga Moteatea, 346 c.f. Leather \& Hall, op.cit. 4-5. 
Patterson suggests the basket concept puts a limit on knowledge and quotes Salmond as his authority that for Maori, knowledge is finitely bounded and closed. ${ }^{159}$ Here I would differ with Patterson and quote a Maori proverb.

'Kaore au e mate he kakano i ruia mai i Rangiatea: I will not die because I am a seed sown from Rangiatea.'

I have heard this phrase used to explain the struggle for the Maori language, Te Reo Maori, to survive. Rangiatea is one of the island homelands from where the Maori ancestors came and the tupuna were just like seeds transplanted to Aotearoa/New Zealand. Today's descendents are the growth that has evolved over thousands of years. We have already explored a description of creation as evolutionary development. ${ }^{160}$ And King says knowledge was regarded as having a mauri or life force of its own capable of contributing to the life force of the person who absorbed it. Knowledge was power but capable of harming bearers who abused it. So the concept of tapu is a way of addressing this mis-use, similar to the Indian concept of verbal testimony where the narrator must be truthful for knowledge to be successfully passed on. The traditional narrative of Tane's three baskets of knowledge suggests there is no limit to the knowledge that can be known. What is being talked about is not just ritual knowledge but the manner in which the mauri of the knowledge needs to be respected. An example could be that a son is not to speak on ritual occasions when his father is present, because the son may take the father's mauri away. But even here evolutionary ethics apply because my father encouraged me to speak so that I could gain the practice. Of course I asked beforehand for his permission as an attitude of respect for the speaking knowledge he had taught me.

Another aspect of tapu is that some of the bearer's mauri is shed when tapu information is passed on. ${ }^{161}$ Rangihau is talking about tapu knowledge, such as carried by a tohunga or elder but this knowledge belongs to the tribe as a continuing entity and needs to be passed on. But a loss of mauri would be expected if we accepted King's contention that knowledge carried mauri. It would have been absorbed into the bearer's personal mauri, so the knowledge passed on carried accumulated mauri.

My analogy is thinking of aluminium as knowledge. Aluminium possesses mauri as a base metal. When it is smelted and fabricated into aluminium windows (the bearer), its mauri continues and probably increases depending on the functionality of the aluminium window. This follows if we accept what was said at the beginning of this chapter about weaving. Here working with mauri in materials reveals new value. When the window is melted down, the base essence still retains the mauri. This analogy compares matter in the scientific sense with mauri, which carries an additional value of motivation and respect. So there is respect for metal and the bearer of knowledge.

The respect that is accorded in mauri has no limit as long as that respect is passed on. It's tikanga or functionality, is passed on like the aluminium that is able to be fabricated into aluminium windows. Respect has no limits.

\footnotetext{
${ }^{159}$ Patterson 1992, op.cit. 163.

160 Ibid, 156.

161 Ibid, 31.
} 
A further point to suggest that a Maori view had no boundaries to knowledge, is that both Henare and Penetito see Maori as actively engaging with Pakeha philosophy and technology. Penetito talks of Matauranga Maori as Maori knowledge acknowledging two sources of knowing (Maori and Pakeha), embracing the past, acting on the present and planning for the future. ${ }^{162}$ Henare's koru of Maori ethics is prescriptive and open to evaluation and questioning in order to seek that which is 'tika' or functional. ${ }^{163}$ This questioning can also be seen as a craving in humans for the unknown and a search for the unknowable. Shaw says no matter how much we know, we can say we could have known more and similarly no matter how many righteous acts I perform, I could say, "I could have performed more." Therefore human beings participate in infinity at the level of knowledge and morality.

“........we cannot draw any limit to our knowledge, practise of dharma, compassion, or love." 164

This is an admirable attitude to adopting an openness to new information. Even Patterson's argument gets sidetracked by assigning tapu, of necessity, to the nature of transmitting knowledge to ensure it is not tampered with. ${ }^{165}$ This seems to conflate the transmission method with the content. It is not that Maori were against writing anything down. They did in fact do the equivalent by using oral testimony. Like other people in pre-literate societies, Maori stored information in stories, proverbs, songs, carvings, games and weaving. While more validity is given to the written word because oral testimony is thought to suffer from faulty recall, these written documents came from the oral record. Oral testimony was the teaching basis for traditional whare wananga, a system of education that continued after contact with Pakeha colonial society (exemplified by the Matorohanga teachings in the records of the Polynesian Society). ${ }^{166}$ The values of the whare wananga that carried what became known as, Maori culture, then confronted and engaged with a Pakeha philosophy aided and abetted by the evolutionary ethic of Maori philosophy. British historian Paul Thompson:

"......wonders how oral history as the 'first kind of history' lost its original eminence when instances of oral tradition in pre-literate societies are easily found that have been vindicated by classical scholarship and archeology." 167

It is really important to be able to rely on the meaning of words to have an oral tradition. An Indian logician said the primary meaning of a word is known at first either through some authority e.g. a person or dictionary, or inferring the meaning from the many contexts where the word occurs. Where the word is used in a secondary figurative sense that conflicts with the primary meaning, it is the motive of the speaker or the writer that is examined in the context of its use to reveal the meaning. Words can also have suggested meaning and this is common with poetic or narrative traditions. ${ }^{168}$

\footnotetext{
162 Penetito, op.cit. 132.

163 Tapine, op.cit. 8.

164 Shaw 2011, Freedom: East and West, (Online, Sophia/ Springer, 26 April 2011), 4.

165 Patterson, op.cit. 164.

166 Polynesian Society founded by Percy Smith and Elsdon Best and supported by Apirana Ngata.

167 Leather \& Hall, op.cit. 8.

${ }^{168}$ D Datta, The Six Ways of Knowing (London, Allen \&Unwin: 1932), 290-292.
} 
An example of suggested meaning is a Tuhoe tribal saying, 'Tuhoe, moumou kai, moumou taonga, moumou tangata ki te po.' This translates as 'Tuhoe wasteful of food, wasteful of treasures, wasters of men to death.' However it really means the generosity of Tuhoe people in providing for their guests and bestowing gifts, as well as the determination with which they pursued their enemies! ${ }^{169}$

The importance of oral history is that it reflects an authentic view that has stood the test of time. It is shaped by circumstance and fortune but the models of imitating the ancestors encourage continuity. For Maori, this has been the primacy of the tribe as a relational connection between generations and their natural environment. Here a balanced harmony is the primary philosophy linking the world of humans and non-humans, between the animate and the inanimate. Oral histories far outweigh the time span of written histories. Darwin's discoveries about the evolution of human beings point to millions of years while the oldest recorded human histories are the Vedas, estimated at approximately the middle of the second millennium before Christ. ${ }^{170}$

So drawing these threads together about Tane's baskets of knowledge, I do not agree with Patterson's contention that to Maori, knowledge was finite. To Patterson this explained the oral tradition of Maori committing traditional knowledge to memory to ensure its word-perfect transmission. As the emphasis by Rangihau was on ritual knowledge, I believe it is the basket of knowledge of karakia and ritual which has the more tapu nature but even then, the ritual knowledge was not finite. As we shall shortly see, karakia was no mere recitation of word-perfect phrases as it was called to mediate in many and varied everyday situations. Patterson himself sees karakia being still used widely today to maintain the good health and well-being of the universe as a whole. ${ }^{171}$ But that does not mean that tapu prohibitions do not operate. My explanation is that committing knowledge of traditions to memory does tend to encourage respect for its integrity and any teacher pupil relationship which encourages a deep respect for knowledge has a better chance to realize this goal. This is what is behind the Indian philosophic tradition of guru (wise teacher) and pupil where the verbal testimony has a 'truth' value just as it was practised by tohunga like Kereopa and Marsden. Being aware of the set apart (tapu) nature of the learning exchange is a Maori value or virtue ethic implicit in the practice. The importance of truth for explanation in the Maori world, was that it was realized not by knowing or accumulating information but because it was practised.

By understanding the potential of tikanga to be practised as 'virtue ethics', or what we 'ought to do,' a flexibility or dynamism to learn more, allows for new experience in all generations. ${ }^{172}$

It is this knowledge as tikanga that functions in its time, that tohunga Kereopa hoped would become tradition for all New Zealanders.

\footnotetext{
${ }^{169}$ http://www.teureweratreks.co.nz accessed 10.36PM 31/1/2012

${ }^{170}$ S Chatterjee \& D Datta, An Introduction to Indian Philosophy (Calcutta, University of Calcutta: 1939), 23 \& M Hiriyanna, Outlines of Indian Philosophy (London, Allen \& Unwin: 1968), 13.

171 Patterson, op.cit. 156.

${ }^{172}$ R Perret \& J Patterson 1991, Virtue Ethics and Maori Ethics in Philosophy East and West 41, 185-202.
} 
Thus innovation challenges the old tradition but in time becomes accepted as tradition. A French philosopher, Ricoeur, says the narrative allows for reinvention that initially upsets the tradition before settling in to be disturbed in the future by reinterpretation of the narrative. ${ }^{173}$

Kereopa said that tikanga as values that are not understood, are pointless. He was talking about the preoccupation of some contemporary Maori with tangihanga funeral rituals, like headstone unveilings. Kereopa claimed the tikanga or function had been lost in the rituals when it was the relationships with the living that were the 'headstones' by which the dead are remembered. ${ }^{174}$

Remember the traditional Maori values we are describing, came from a time before Pakeha settlement when the tikanga performed a balancing act with the environment. Patterson describes it as an environmental holistic philosophy, not one of human beings dominating nature but seeing kinship and harmony with it. ${ }^{175}$

\section{Karakia as mediating values}

For Maori, traditional values embodied not only a cosmology of humans as part of creation but also incorporated a 'how to' guide of how it worked. Raerino talks of a tradition of karakia (ritual prayer) "....to intervene or mediate the human condition." The purpose of his thesis was to provide an insight into traditional Maori thinking, as Raerino says karakia have tended to remain uncorrupted in their original usage since the arrival of the Pakeha. ${ }^{176}$

Karakia could be understood as ritual spoken mediations or as I heard one Maori health worker recently tell a hui, 'talking to the problem.' The context was dealing with Maori patients worried about accepting a donor's blood because of tapu prohibitions on bodily fluids. A karakia could be just asking the patient's body to accept the blood of the donor to make it get well again e.g. "Whakaorangia te tinana o te turoro nei kia ahei te mauri o te rongoa hei painga mona." ${ }^{177}$

Raerino's thesis describes how karakia enabled the transition of individuals through their daily lives.

"Maori made choices in respect of attempting to mediate the reality of everyday existence and the necessity to maintain a psychological, physical and emotional harmony with the power of Atua (super natural forces) which also influenced their behaviours." ${ }^{178}$

The practice of mediating suggests Maori tohunga experienced a mutuality of influence and were affected by natural forces as well as affecting natural forces. These forces could be described as spiritual. Maui stories were a traditional narrative that spoke of a mischievous demigod who attempted to change the course of things such as slowing down the pace of the sun by tying it down. But Maui needed powerful karakia to make the ropes strong enough.

\footnotetext{
${ }^{173}$ Wood 1991, op.cit. 25.

${ }^{174}$ Moon, op.cit. 122.

175 Patterson, op.cit. 126-129.

${ }^{176}$ N Raerino 1999, Koi Ro Pure Me Karakia E Oke Ana (Auckland, Auckland University: 1999), 1.

177 The writers's own words.

${ }^{178}$ Raerino, op.cit. 2.
} 
And of course he didn't always get his own way, as he found when Hine Titama crushed him between her thighs as he attempted to crawl into her womb to become immortal. ${ }^{179}$ So the role model of the ancestors as patterns to follow, seems to be that influencing the gods or natural forces is a balancing act. It depends on good ritual knowledge and both an attitude of respect and determination to improve the lot of the tribe.

"In my early years I can remember karakia being an important part of the life of the marae and that of the people who went fishing, played sport, and those who attended school. Nothing really began, unless some form of karakia, whether it was the Ringatu or the old form of ........certain places took place." ${ }^{180}$

Rituals constitute significant links between past and present. Spiritual entities like mauri (life force) are thought to be subject to, not so much laws of science, but Maori ritual lore. We have seen that imitating the model of the ancestors means valuing their deeds as ideals to be followed. Relationships in narratives matter more than what happened and the collective nature of kinship and tribal mana or respect connects the past in the present. Thus rituals are part of the accompaniment that ensures the Maori world functions appropriately or 'tika.' The comparable Indian concept for karakia is Vrata, the aspect of observances and performances of sastric rites, rituals and duties. Vrata accompanies the moral aspect (Rta) and the spiritual aspect (Dharma) for a more rounded Indian worldview of Dharmasastra as a science of righteousness. ${ }^{181}$

An example of an Indian ritual relates to duties towards other human beings. It is said that no one has a right to live in a house until they build one for the poor or anybody who needs shelter. The house should be open to anybody who is poor or suffering.

"No man has the right to cook food only for himself; it is for others, and he should have what remains."

The ritual of cooking food for others also applies to animals.

"One portion of food cooked in household belongs to the animals also...they should be fed and taken care of." 182

And in the texts of Manu, ${ }^{183}$ which outline sastric rites, rituals and duties "......there is even provision for expiation in causing injury to the tree with fruits and flowers." ${ }^{184}$ This is analogous with the karakia that Rata forgot to offer when he felled a tree in the forest of the god, Tane.

\footnotetext{
${ }^{179}$ Patterson, op.cit. 166-174.

${ }^{180}$ Raerino, op.cit. 18.

181 Jha, op.cit. 5-18.

182 S Vivekananda, The Complete Works of Swami Vivekananda, Mayavati Memorial (ed.) Vol IV (Kolkata, Advaita Ashrama: 2001), 9-10.

${ }^{183} \mathrm{G}$ Buhler (translator) The Laws of Manu (Oxford, Sacred Books of the East XXV: 1886), IX, 143.

184 Jha, op.cit. 17.
} 
“Before natural resources are appropriated for man's use, propriatory rites to the appropriate deity must be observed. Their observance ensures that nature is not treated wantonly but with care and respect." 185

So for a Maori worldview, ritual karakia must be recited from time to time if the mauri of the world is to continue to flourish. ${ }^{186}$ This is an important point when we consider in later chapters, how Maori values have influenced Pakeha values in contemporary events in the life of Aotearoa/New Zealand, such as treaty settlements and even engaging a tohunga (ritual expert) to clear a path for roads through tapu areas. $^{187}$

To Maori, using karakia was a way of living in harmony with the world, a world of right relationships. It was Platonic and goal oriented and expressed through tikanga or proper actions. Plato saw reason expressed in the goal which was not the same as the cause. The goal of humans was to realise the 'Good,' that is contribute to the order of the world from their station in life. As reason was not just in human beings but also in nature, Plato claimed that the order of the world needed to be understood by humans because they needed to know how to co-relate with it.

"Accordingly the purpose which dominates his life, the good for which he lives, will be good in itself in proportion as it serves a wider purpose, and ultimately the purpose or good of the order of the world." ${ }^{188}$

When compared with Raerino's explanation of karakia as mediations between worlds, Plato could be describing a similar process that promotes a value of seeking harmony between humans as well as mediating with the order of the natural world. This could be expressed as harmony between humans, between living things and between the living and the non-living.

This harmony that karakia is aiming to facilitate, is greatly helped in the Maori case by the collectivity of actions. To a Pakeha point of view, a community gets its constituency from members past and present and their relations. Society brings together individuals. A Maori view is that the common will is rooted in something deeper, as our narratives of traditional life have shown. Kinship is whakapapa, genealogical descent from the gods and linked to the land as Earth mother and through her to all living creatures as cousins. ${ }^{189}$ Without kin, past and present, persons are nothing.

\footnotetext{
${ }^{185}$ Walker, op.cit. 29.

${ }^{186}$ Patterson, op.cit. 64.

${ }^{187}$ A Reedy, personal communication, 2010.

${ }^{188}$ Nettleship, op.cit. 227.

${ }^{189}$ Patterson 2000, op.cit. 14
} 


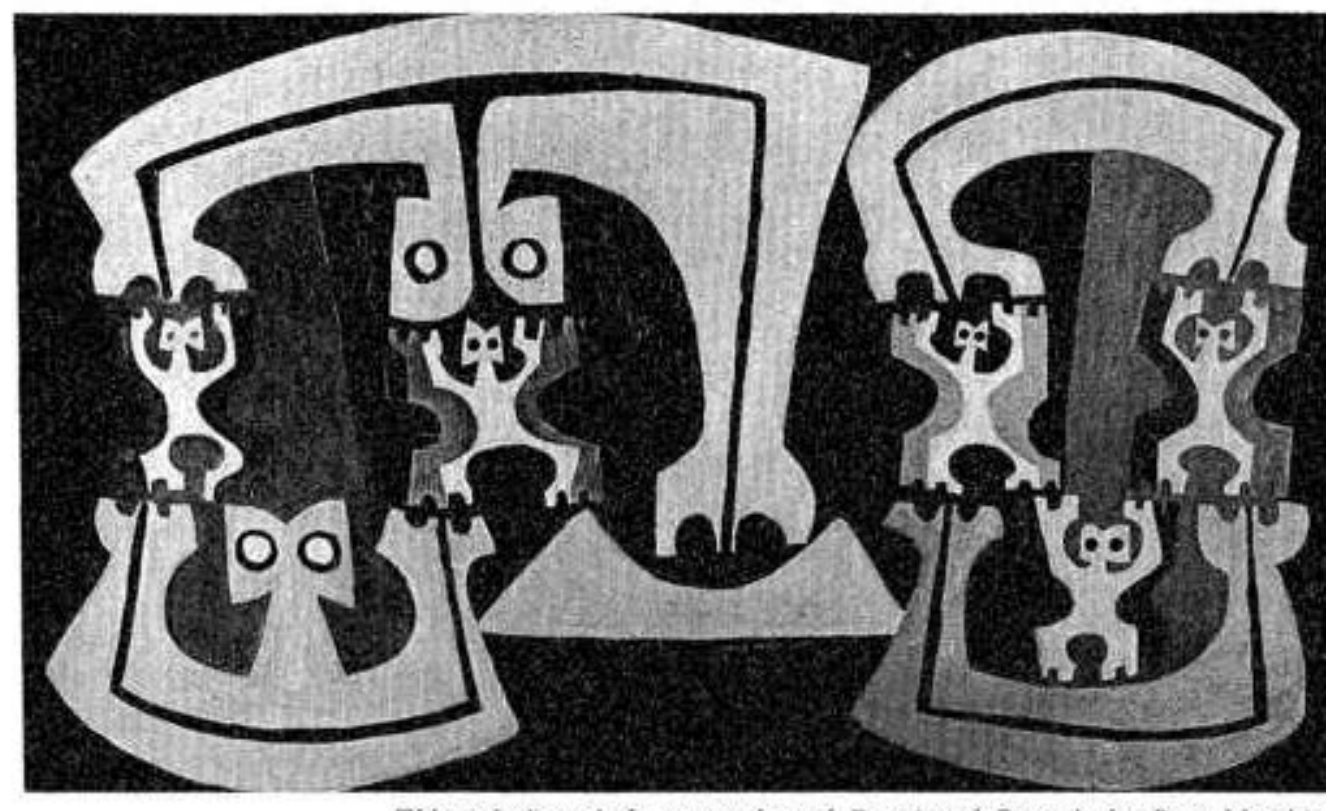

This painting of the separation of Rangi and Papa is by Para Matchit

This photo from Te Ao Hou magazine of Ranginui and Papatuanuku shows our human kinship with the gods.

A consequence of this view of the nature of the individual is that it often does not much matter which member of a kin performs an action, or reacts to one from outside, or is reacted against." ${ }^{190}$

The important reality is the focus is on the community rather than the individual. This community focus is a Maori philosophical value that is needed in the concluding chapter, where we look to find common solutions to promote harmony in Aotearoa between Maori and Pakeha worldviews.

But as I have said, human beings can always learn more, so freedom is needed to acquire new knowledge and so adapt tikanga to changing circumstances. The Good is in us but we need education to realise it. By education I mean an attitude of openness to challenging my own values before questioning the values of others. Perrett and Patterson believed Maori philosophy to be 'open-ended' when practised as 'virtue ethics.' ${ }^{191}$ This dynamism allowed for new experience and new traditions and both Kereopa ${ }^{192}$ and Marsden agreed. ${ }^{193}$

Contemporary tohunga (ritual experts), Reedy and Raerino both say karakia are descriptions of intention or goal oriented. From a Maori point of view, the use of karakia makes sense. It is rational in the Platonic sense of humans needing to know how to relate to the natural world. Also it is the practise of 'virtue ethics' according to Patterson where Maori values, such as the tikanga of karakia, are in accord with customs or common practice and by following such, you become a full human being. ${ }^{194}$ This means there is group responsibility as well as society as a whole being responsible.

\footnotetext{
190 Ibid, 153.

191 Perret \& Patterson op.cit. 185-202.

192 Moon, op.cit. 122.

${ }^{193}$ Marsden, op.cit. xi.

${ }^{194}$ Patterson, op.cit. 102.
} 
Currently, use of karakia is gaining public acceptance and may in time become a norm or tradition of Aotearoa/New Zealand.

This chapter on Maori values has shown that the openness of the traditional Maori world allowed for individual mana to be expressed within a moral kinship group that made up the communal good. We noted that a Maori value of collective responsibility had seeds for harmony in a contemporary New Zealand, where selfish individual values and consumerism need to be linked to the common good. This Maori collectivity is currently being realized in Iwi (tribal)health providers and other social service delivery systems. But it has the conceptual and cultural base of values to be considered as ingredients for a uniquely New Zealand model of Dharmasastra, a social science where all people accept a relationship of social obligations. But to move through to contemporary New Zealand values in this thesis, we must first understand the effect of the values of Pakeha colonisation on the Maori worldview. This is the focus of the next chapter. 


\section{CHAPTER TWO: THE EFFECT OF PAKEHA VALUES ON MAORI VALUES}

Here I will outline the world views of the Pakeha settlers of New Zealand and the values they spoke of and then look at their practise just as I did in the previous chapter about Maori values. Where idealised values were not followed up, a check of the historical record will be made to give explanations. I take my lead from the Indian tradition that sees philosophy as the lamp shedding light on all sciences and also the Platonic tradition of testing concepts with reason.

Plato emphasized the soul of mankind, and later in his writings in The Republic, developed the concepts of rationality and irrationality and the relation between ideas. His pupil, Aristotle emphasized reason and is credited with the teaching of correlating ends with means. Both philosophers' ideas are critiqued in this chapter.

\section{Who is my neighbor?}

When settlers arrived in numbers in the 1840's, they had little food or shelter particularly in Wellington where the Wakefield Company did not deliver on its promises of sections for settlers because it had not bought the land off Maori. So as explained in the previous chapter, the Maori concept of kinship, mana and hospitality applied. Local Maori oral histories tell of settler families being housed and fed. Both Patterson ${ }^{195}$ and Henare ${ }^{196}$ have stressed that the tikanga of mana, seen as the function of authority, required a tribe to have standing within the land area and so be able to balance the sometimes competing needs of humans and the local environment. In early Wellington's case, these needs were immigrants and no homes.

Of course local Maori had little idea of the pressure that continuing settlement would mean to their own survival. But hospitality to others was part of that kinship value, as one has special responsibility towards guests. ${ }^{197}$ The religion of the settlers also professed a kinship value, expressed as loving your neighbor, but that concept of neighbor was restricted to settlers. Whanaungatanga (kinship) had a much wider value application in the Maori world-view than the Christianity of the settlers, so let's look at the values of religion and the environment in which it was applied. The settlers' religion was overwhelmingly the Christianity of the Church of England followed by Catholicism, Presbyterianism and Methodism. Christianity was also associated with colonial power and the ideology of superiority inherent in Imperialism. ${ }^{198}$

\footnotetext{
195 Patterson 2000, op.cit. 20.

196 Tapine, op.cit. 8.

197 Patterson 1992, op.cit. 64.

198 D Pearson, A Dream Deferred (Wellington, Allan \& Unwin, 1990), 27.
} 
Colonialism has also been expressed as the operational arm of Imperialism. ${ }^{199}$ An ideology is a particular type of mindset, some examples are capitalism (workers' labour provides a surplus output that is equated as profit for the employer); socialism (workers' labour output belongs to the workers as a collective); egalitarianism (when all members of a society have equal opportunity and are able to realize their potential).

The Christianity of the missionaries had a major impact on Maori as this ideology was intertwined with the politics of also being a colonizing agent. Missionaries encouraged a new Maori identity based on conversion to Christianity and new alliances between tribes and even an abandonment of tribal difference. ${ }^{200}$ As such, Christianity had some influence in the Pakeha overtures from France (at Akaroa) and America (Northland) as well as from Britain in the early nineteenth century. But there is debate about the extent of that influence pre-Treaty. The Declaration of Independence of the United Tribes of New Zealand in 1834 was one manifestation of Pakeha and Maori minds meeting. It might be thought that if independence was declared, then why the need for another treaty six years later at Waitangi. This was because the United Tribes of New Zealand was still a fledgling concept But Henare says the Declaration is evidence that Northern Maori leaders understood the European concept of nationhood and were proclaiming their coming together. ${ }^{201}$ This was a prelude to the full-blown concept of a treaty between two sovereign nations, where Christian influence via the missionary Williams, was to the forefront at Waitangi in 1840.

However the language of the Treaty was a distortion of Maori words and the ramifications continue today. Given the colonial past of Britain and its actions towards Canada and Australia, it is hard to accept the distortions were innocent but in fact intended to mislead. ${ }^{202}$

In brief the Treaty signed at Waitangi had at least three articles written in the Maori language. The first acknowledged that the Maori chiefs signed over the governorship of their lands to the Queen of England. In the second, the Queen recognized the Maori chiefs' sovereignty over all their lands and treasured possessions. And in the third article, Maori are given the rights and privileges of British citizenship. Contemporary disagreement is over a question of values expressed in the translated words, governorship and sovereignty. Kawanatanga is compared with the concept of King Herod's governorship being valued like a junior partner within the Roman State. Rangatiratanga is conceptually advanced as the full authority of Julius Caesar. In the Maori version which the chiefs signed, their rangatiratanga was assured and it was only a junior partnership role they were allocating to the Queen's British representatives. But different words were used in the English language version, Maori giving over their sovereignty in exchange for a guarantee of 'full, exclusive and undisturbed possession of their lands, estates, forests, fisheries and other properties....'

\footnotetext{
${ }^{199}$ E Said, Culture and Imperialism (New York, Random House, 1993), 9.

${ }^{200}$ M Durie, Te Mana Te Kawanatanga: The Politics of Maori Self-Determination (Auckland, Oxford University Press New Zealand: 1998), 53.

${ }^{201}$ Henare 2003, op.cit. $17-18$

${ }^{202}$ Pearson, op.cit.29
} 
However the English language version, signed by 39 chiefs, has been preferred since 1841, despite the Maori version gathering 512 signatures as it travelled the country soon after its Waitangi signing. ${ }^{203}$

Another way of viewing the Treaty articles written in the Maori language, is that Britain was offering to become the administrator of Aotearoa but that the ownership would remain with Maori. A further analogy is to think of a case of your car breaking down. The person who repairs the car does not then automatically own the car!

For all that, the Treaty has had a mixed fortune. While it legalized the colonization of New Zealand as a British outpost, it was soon seen by the colonial government and Britain as a 'simple nullity' with no standing in law. Many petitions and visits by Maori to attempt to see the Queen of England followed but it was over one hundred years later that a judge Prendergast in a New Zealand court case recognized the Treaty as "......essential to the foundation of New Zealand," and "....part of the fabric of New Zealand society." 204

Another aspect of the Treaty relevant to our discussion about spirituality is Article Four. This section is said by historians to have been inserted into the Treaty by the Anglican missionaries to ensure a favoured status for their religion. However along with promising religious freedom to Maori (whatever that meant to them in 1840), the Maori language version of the Treaty talks of recognizing 'ritenga Maori' as a practice alongside other hahi (churches). Originally translated as Maori rituals or practices, 'ritenga Maori' came to be seen in contemporary New Zealand as a spiritual marker that helped promote the Treaty as a spiritual document embodying the wairua and mana of the ancestors who signed it. ${ }^{205}$

With this brief context of Christianity and a Maori worldview, via the work of missionaries and some of the conceptual framing of the Treaty agreement, let's examine a Christian look at Maori values. It is by a contemporary Pakeha writer and clergyman, Phil Cody, who completed his MA thesis in Matauranga Maori or Maori knowledge at a Maori wananga (tertiary learning establishment).

He compares similarities and differences between Maori culture and Christianity, some of which I critique. Cody's similarities are:

- positing a spiritual beginning and ending to life;

- having a basis of aroha in life;

- acknowledging the dignity of each person;

- valuing the role of hospitality;

- valuing land;

- ritualizing different aspects of life;

- humility;

- karakia;

${ }^{203}$ C Orange, The Treaty of Waitangi (Wellington, Allen \& Unwin, 1987), 86-91.

${ }^{204}$ Durie, op.cit. 180-182.

205 Orange, op.cit. 90. 
- $\quad$ respecting the dead and farewelling them;

- acknowledging the spirit;

- seeking unity. 206

At first glance there are similarities but that depends on the interpretation given to words such as 'aroha,' which I think is being used to mean love. The Maori and English words lend themselves to many interpretations. From a Maori value perspective, aroha encompasses empathy, a willingness to see the other's cultural view-point. History shows this plainly did not take generally place in Maori/settler interactions which were marked by inequality in power relations. It is said that the difference between prejudice and racism is power. A worker may have a prejudice against certain types of behaviour or types of people but cannot enforce that prejudice apart from interactions with fellow workers. But if that person has power as an employer or government official, then they may be able to enforce their prejudice. This power is racism in action. So saying that Maori culture and Christianity were similar in having a basis of aroha in life removes the value from the context in which it is practised. The aroha in the life of the settler was primarily practised within a class-based community competing with each other for resources and also competing as a settler community for Maori resources. Even within the settler family, the aroha was based on colonial hierarchical values that placed males before females.

Comparison with the aroha of Maori culture reveals a much wider conception of who is my neighbor. As commented on in the first chapter, whakapapa (interconnection) and whanaungatanga (kinship) meant an interlocking system of responsibilities and obligations upheld a unity that was realized in practice, in communal work and thinking. When compared with the love preached as an ideal of Christianity and sparingly administered in practice among Christians, any similarity with the aroha of Maori culture pales. Similarly drawing favourable comparisons between the role of hospitality in Christianity and Maori culture overlooks the colonial legacy that hospitality was not mutual. Maori were the hosts who originally volunteered their resources, perhaps in the cultural expectation that it would be reciprocated or if we take Patterson's view, even expanded.

But the market philosophy of colonialism that needed to supply the mother country with resources from around the world, found no room for sharing without some monetary return. If these comments about similarities seem rooted in the colonial past and missing a contemporary context, then let's turn to the situation today in Aotearoa/New Zealand. What has changed in the operation of those two values of aroha (love) and hospitality in the Maori and Pakeha value worlds? Pakeha culture has built on the settler market ideology and what is valued is what can be bought and sold. Aroha plays little part in this ideology, as love is limited by self-interest amongst a chosen few. Gender inequalities have still not been eliminated in the Pakeha world while bigger socio-economic gaps have emerged between 'the haves and the have nots' as evidenced globally.

${ }^{206}$ Cody, op.cit. 96. 
Sadly Maori culture has been degraded also and the values more like ideals or 'virtue ethics' than practices. Thus aroha has come to mean either simply understanding or feeling sorry for someone down on their luck. Action to redress the imbalance is not always forthcoming as more often than not, a lot more in the community are feeling emotionally and economically stretched.

When a member of a family is involved in wrong-doing, Maori may say they feel aroha for the whanau (extended family). But there is not a lot that can be done by the community as the New Zealand justice system is still foreign to Maori and cloaked in British laws and rituals that are more punitive than restorative. Hospitality too is a more considered response now, but it is still practised at the core of Maori hui (gatherings). Harder socio-economic times have meant that more inventive ways to show hospitality and recharge the mana of an occasion are used, such as fundraisers like 'housie' (a game of chance) and 'charity auctions'(donated goods are sold to the highest bidder), where people can spend money with the hope of a lucky prize.

As this is a thesis on Maori and Pakeha values that can have a common goal, caution needs to be shown towards a superficial comparison. It is only by digging down into the roots of the practise of the values and exposing the context that understanding another's values is possible.

Continuing our spiritual comparison, Cody goes on to cite one difference between Maori culture and Christianity:

- The god of Christianity is a personal loving god called 'father' by his son Jesus and us. The Maori god remains distant although called a parent; ${ }^{207}$

Patterson describes the Maori creator relationship differently. There is no single being who stands over the universe as in the Jewish-Christian narrative. There may be one who engineered the first stage but plays no active part now. But the relationship with the world is what matters and this is expressed in kinship, not master and subject. The Judeo concept may claim a loving god that created human beings but the parent relationship of Christianity could be seen to be an idealized one perhaps just as distant as for Maori. And the Judeo-Christian concept of 'man' being superior to the natural world, compounds the distance into an environmentally unfriendly stance of not seeing the imperative to value all creation as kin. $^{208}$

We continue Cody's comparison between the values of Christianity and a Maori worldview.

- Maori culture has no sense of 'fall', a need for redemption

- Christianity stresses god's son, Jesus, as savior;

- Jesus is unique. In Jesus, god shares human nature. Jesus lives inside the believer;

- The Eucharist (consecrated bread) brings Jesus body as healing;

${ }^{207}$ Ibid, 98.

${ }^{208}$ Patterson 2000, op.cit. 70. 
- Christian faith is a gift not earned by birth or won by power or knowledge. Whakapono (faith) is not a word integral to Maori language; ${ }^{209}$

My thought is that faith or belief had no place in the Maori world as a concept because the philosophy was to follow the model of the ancestors and live the life of the tribe. Whakapapa, as relation and interconnection, placed you in the stream of life and sustained you. As discussed in the previous chapter, any question of why tikanga (function) was done did not need blind faith or belief, it could be explained that it demonstrated an attitude of respect and led to goals of unity and harmony. This Maori goaloriented philosophy is Aristotelean in equating ends with reason or rationality, a product of Plato's 'Good' as the end goal of human intelligence. Plato further developed the concept of human reason as the means by which knowing comes to be.

In The Republic, Plato said “.... the ideal of a man's life might equally well be described as perfect knowledge and understanding...." 210

And Plato has described the difference between knowledge and belief. Knowledge can give an account of why something is so through sense data. It does not change with circumstance and is the same knowledge today and tomorrow. Belief however depends not on sense but on emotion and this can change with circumstance, so beliefs are not the same today and next year but can change in time. Later in life, Plato amended his concept to incorporate belief as knowledge if an account can be given that justified this belief. My example concerns a belief of a previous century, that perhaps swans other than white existed. It was a belief and not knowledge because no other colour than white had been discovered. The belief could not be justified to make it knowledge. It remained a belief. But when black swans were discovered that belief had been justified, an account could be given from sense data. Thus knowledge can also come from a justified true belief. This reasoning attitude is reflected well by Indian Nobel Laureate, Amartya Sen, who qualified the title of his book, The Argumentative Indian by saying there is nothing like blind faith, there is only debate and reason. ${ }^{211} \mathrm{He}$ is continuing a long Indian philosophic tradition that reaches back to the Vedas of the second millennium B.C.

"There are three powers to draw from: the sastras, the teacher and one's self. Everywhere there is human exertion. There is never fate." ${ }^{212}$

Because of the value of debate and reason, we continue Cody's comparison of Maori and Christianity world-views to tease out the impact of Pakeha values:

- Christianity speaks of a personal eternal life, Maori speak of a common world of spirits after death;

- Christianity has a concept of $\sin$ as a conscious offence against God. ${ }^{213}$

${ }^{209}$ Cody, op.cit. 98.

${ }^{210}$ Nettleship, op.cit. 229.

${ }^{211}$ A Sen, The Argumentative Indian ( London, Penguin Group: 2005),25.

${ }^{212}$ Chapple, op.cit. 110.

${ }^{213}$ Cody op.cit. 99. 


\section{Hara is not like sin}

Maori had no concept of that Christian type of $\sin$. The Maori hara ( $\sin$ ) can be an unconscious infringement of tapu. This is because tapu has a collective nature, being the weaving of the gods and described by Patterson as 'hard mana.' Tapu is binding as well as bonding with repercussions for the future if transgressed with a 'hara.' There is a comparable sense of Christian sin also being unconscious as in the concept of 'original sin.' Here the individual is not responsible for the offense as it comes from the first parents. But the sin is atoned for by accepting Jesus as atonement. ${ }^{214}$

As this chapter is concentrating on looking at the effect of Pakeha settler beliefs on Maori values, let's examine the concept of hara or infringement. On closer look hara is not like the Christian 'sin,' if one follows church teaching and sees sin as a conscious rejection of God's will. But there is also that Christian teaching of 'original sin,' where humanity suffers from the original rejection of God by the ancestors and needs spiritual help to get back in the good books. A Christian psychiatrist gives a biblical explanation of sin, as the time when free will was exercised and knowledge of good and bad was discovered by the first human parents, personified by the writers of the bible as Adam and Eve. Peck explains sin as us humans, through our ancestors, having to take responsibility for our freedom:

"We became self conscious......as separate entities. We lost oneness with nature, with the rest of the universe." 215

This explanation suggests the concept of 'hara' to me, as an infringement humans have inherited. On one hand it was an intentional infringement by our ancestors but an unintentional infringement by us. The trouble is that Maori are in a world of mutual interdependence with the environment, needing to be in balance to be functioning. Thus the purpose of tikanga is more clearly revealed as functioning in the larger perspective. Mauri was described as the life principle and mana, the exercise of authority to enable human creativity. To balance out this authority, the principle of tapu dealt with infringements or hara. Hara could come from such things as, knowingly or unknowingly disturbing grave sites or sacred places or coming into contact with the personal possessions of tapu people which would violate the domains of tapu (set apart) and ordinary (noa or not tapu). These prohibitions are similar to accounts of Jewish purity rituals as well as the purity prohibitions of some Indian sects. Just as the Levitical Laws were an external reminder of the Jews' intimate union with Yahweh, so behind tapu infringement was the need to keep all in balance. Tapu incorporated the 'rangatira' values as ethical demands or virtues. To practise the virtues was to be a rangatira, a person wanting to be set apart. ${ }^{216}$ Being set apart in Hebrew translated as being 'holy,' or tapu.

To be unaware of one's environment and capable of infringing, meant Maori were encouraged to be aware and practise such virtues as aroha ki te tangata (respect for humanity), manaakitanga (hospitality) and tiakitanga (caring). A popular Maori saying values people above all things.

\footnotetext{
${ }^{214}$ Starting Point Study Bible (U.S.A., Zondervan, 2002), 1630.

${ }^{215}$ S Peck, Further Along The Road Less Travelled, (New York, Simon \& Schuster, 1993), 18.

${ }^{216}$ Patterson 1992, op.cit. 102.
} 
'Hutia te rito o te harakeke, kei hea te komako e ko. Ki mai he aha te mea nui i te ao. Maku e ki atu, he tangata, he tangata, he tangata.'

If you rip out the heart of the flax-bush, where will the bell-bird feed. So too humans are essential to the creativity of life.

This is a prescriptive philosophy to realise the goals of life. Of course tohunga, Raerino, has also made clear that Maori were not left empty-handed in their day to day transitions between tapu and noa. As he has explained, karakia were descriptions of intentions to move between, not just earthly domains but also spiritual ones. Three domains are described by Raerino: the realm above of the Atua or gods; the earthly realm where 'pure' (human actions) were needed to make conditions appropriate for karakia to work as invoking and mediating Atua; and the realm of Atua in 'Rarohenga' (underworld/below). This concept is different from a Pakeha concept. Gods are not fixed in place, rather they are moving between realms above and below the Earth.

Another way to picture this is to remember the Creation narrative of Papatuanuku (Earth mother) being separated from her husband in the sky (Ranginui) by their children who lived mostly in-between. And one of these children, Tane is the ancestor of humans.

The following diagram is Raerino's realms

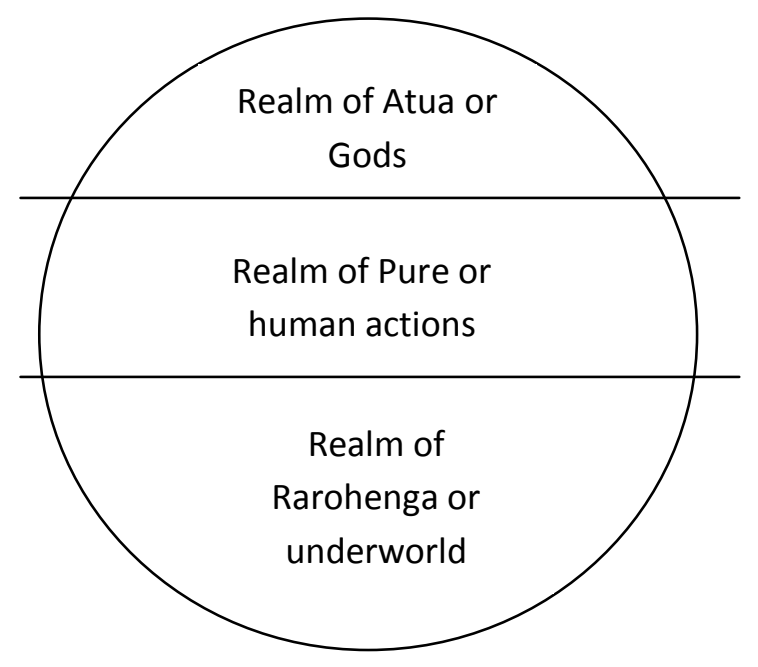


Thus karakia could be seen as unblocking that which interrupts the free-flow of energies which are needed to maintain an individuals' balance. ${ }^{217}$ So in as much as the principle of hara contributed to the need to balance, similar could be said for the Christian concept of sin. In this thesis of Maori and Pakeha values, common values and ground can be claimed for Maori and Pakeha by not focusing on the fault or infringements in our past but instead on the remedy. For Maori that remedy can be the use of karakia to free up a person's mental outlook that usually manifests in bodily illness. For Pakeha who see sin as not achieving their full potential, prayer and meditation can address a spiritual in-balance and restore full function. Another analogy involving prayer comes from a native American tradition where fear is seen as the door of the heart that lets evil spirits in. Real prayer is about building up the heart to be strong so that fear doesn't enter. Even the more secular Maori and Pakeha could benefit from holistic practices like yoga and exercise where mind and body are addressed together. In Indian philosophy, yoga is part of a mind and body practice, not a separate exercise as has developed in non-Eastern practice. As the goal of this study of values is harmony between Maori and Pakeha in Aotearoa/New Zealand, less stressed individuals are more likely to lead to less stressed communities.

We continue the comparison of Christianity and a Maori worldview. Unlike Raerino's definition of three spiritual domains for Maori, Christianity had only two spiritual domains according to Cody. There are also:

- two types of karakia, Christian prayer and karakia tawhito (ancient Maori prayer);

- Maori culture has its own tikanga (practices) not to be confused with faith;

- only Maori have atua (deities) however interpreted; Maori are descendants of atua and ultimately of the Supreme Being or God (Io) i.e. Tane, as the ancestor of humans, is also guardian of the forests and is personified in the tree. Similarly a canoe made from a tree means Tane is the canoe.

The implication of this for Cody is that Maori have departmental Gods but he is not understanding the Maori word atua. It has two components, ' $a$ ' and 'tua.' Tua means beyond or the other side and ' $a$ ' is a preposition denoting location. So atua denotes where something is, in this case metaphorically referring to the metaphysical realm beyond. Cody continues;

- $\quad$ some Maori see values such as tapu and noa not to be combined with Christianity;

- Maori spirituality has its own content e.g. mauri (life principle) or hau (vital essence);

- whakapapa has an all-embracing place in Maori culture. ${ }^{218}$

Whakapapa (connection or genealogy) has already been discussed in the first chapter as being the linking of gods with all creation, human and non-human. This linking then gave a kinship identity that stretched back in time and forward to the future.

\footnotetext{
${ }^{217}$ Raerino, op.cit. 7-8.

${ }^{218}$ Cody, op.cit. 99.
} 
Genealogy was also seen to be essential to seeing our ancestral life story as a narrative akin to the examined life that Socrates valued. ${ }^{219}$ Whakapapa as genealogy was also an embedded metaphor for linking past, present and future in a single field of knowledge. ${ }^{220}$

Patterson has based his environmental philosophy for the well-being of Aotearoa, on the Maori concept of kinship between humans and all created things, expressed as 'tangata whenua', people of the land. ${ }^{221}$ His kinship is based on Maori whakapapa or genealogical descent. For Maori, we have already seen that this concept defines who you are as an individual within the collective. Whakapapa from the gods not only brought human life through Tane, but it also birthed other creatures through the Earth mother, Papatuanuku. So the value judgment is that the Earth is a mother who looks after her children but the human response is to in turn, reciprocate. ${ }^{222}$ This is the symbolism of whakapapa stylized as an unfurling fern frond with no beginning and no end, a koru. It is a stylised koru that is painted on the tail of Air New Zealand's planes.

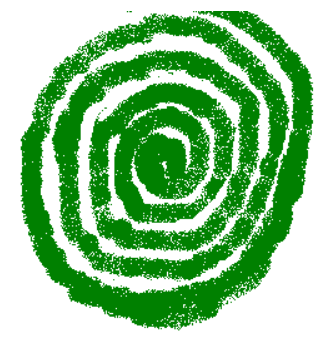

\section{Maori atua as domain 'gods'}

The place of deities may be unnecessarily divisive in our account of similarities and differences between Christianity and Maori beliefs. Today many Maori see belief in 'Maori gods' as incompatible with their Christianity. They accept the Western anthropologist's account that traditionally these deities were worshiped. Their adherence to Christianity follows the preaching of the missionaries and their Maori converts to turn from false gods, such as lo Matua Kore (the supreme god who was uncaused). Here let's define some philosophical terms and compare with Maori tradition.

Deism is a view from Western philosophy that God, having created the world, is disinterested in it. The view can also hold that human reason gives humans all that is needed to live and so a traditional idea of God is unnecessary. ${ }^{223}$ Another way deism can be expressed is that true religion is natural religion and God wants all creatures to be naturally happy and has ordained virtue as the means to it. ${ }^{224}$ This idea of deism may compare to Patterson's 'virtue ethics' to describe a traditional Maori way of living.

\footnotetext{
${ }^{219}$ Wood, op.cit. 20-51.

${ }^{220}$ Walker 1996, op.cit. 13.

${ }^{221}$ Patterson 2000, op.cit. 7.

222 Patterson 1992, op.cit. 157.

223 D Runes, Dictionary of Philosophy (New York, Philosophical Library, 1983), 91.

${ }^{224}$ R Audi, Cambridge Dictionary of Philosophy (New York, Cambridge University Press, 1995), 188.
} 
However Audi goes on to say that in this 'deistic' natural world, where God is an absentee landlord, knowledge is universally accessible and so special revelation is not needed. This seems to disqualify the traditional Maori view where tohunga are needed to mediate between the human and spiritual worlds.

Theism is a concept of God or Gods working in and through the world or a cosmos created by an omnipresent God. ${ }^{225}$ Monotheism is belief in only one God while polytheism is belief in more than one God. $^{226}$

Superficially, traditional Maori belief in atua or domain gods seems to fit with polytheism. Alternatively some Pakeha have taken Maori respect for ancestral mountains or sacred trees like the large kauri tree in Northland, appropriately called Tane - the King of the forest, and classified Maori as worshiping nature. Pantheism is sometimes equated with nature worship, where a higher presence is said to manifest itself throughout all creation and so is revered as being omnipresent. But pantheism is more correctly making God identical with all creation. I think a deeper fit with Maori philosophy is panentheism, where God is seen to be in all things but not identical (as in pantheism). Panentheism can be compared to the water in a sponge, which is not to be equated as being identical with the sponge. ${ }^{227}$ The concept of mauri as life essence comes to mind when comparing with the God of panentheism and for the purposes of this thesis, how it influences values.

If we practise a goal-oriented life with an attitude of respect to the environment, such as the city streets, because they have a mauri, a divine life essence, then we may not litter or encourage wild late night street parties. This respect for the mauri of the urban environment may even encourage us to look after each other as a community when we are socializing late at night, especially the more vulnerable, such as young men and women. The prevalence of young women getting publically drunk in downtown Wellington has necessitated a 'girls protecting each other' advertising campaign that has run for some years. It has been based on the value of self-interest in protecting the people of your group against attack by others. A better remedy would be for people to see themselves in harmony with their urban environment by respecting the environment as a 'divine playground,' where the betterment of all is paramount rather than a 'dog eat dog' scenario where security is valued over peaceful enjoyment by all.

The city is one domain, and if we follow the account that Maori philosophy was holistic, we might see that a series of 'little gods' holding sway over different domains was part of this holistic way of getting through life's experiences. Nearly all indigenous cultures have such 'domain' gods as part of their epistemology, which gives meaning. From my Irish mum's tradition comes St Christopher as the patron saint of travellers and St Jude of lost causes. Because I have lived in that Pakeha Catholic culture, I understand the context of 'domain gods' and thus the value of what is being said. If you are travelling, focusing on guidance seems useful and if you've lost something, it can't hurt to ask for more help. Likewise I can understand the Maori concept of atua and their tikanga or functioning value as kaitiaki or guardians. I can reconcile the two concepts into a useful value.

\footnotetext{
225 Runes, op.cit. 332.

${ }^{226}$ Bunnin, N \& J Yu, The Blackwell Dictionary of Western Philosophy (Malden, MA, Blackwell Publishing, 2004$), 501$.

227 Audi, op.cit. 413.
} 
A tautohetohe (debate) on Maori Television in 2010 illustrated this misunderstanding about Maori atua (deities) and went deeper into the meaning of atua beyond deities, to the notion of guardianship or kaitiakitanga. The moot was that the teaching about Maori deities at kohanga reo and kura kaupapa (Maori education institutions) was contrary to Christianity. One woman negating the proposition described her childhood as acknowledging there were separate domains of resources looked over by kaitiaki or guardians. As a child, she addressed them whenever she sought to fish or eel in the river or dig in the gardens. This was her karakia or acknowledgment as she was growing up and continued with her to the present. She felt teaching this to the next generation was a helpful way to promote values that would enhance relating to the world. ${ }^{228}$

Another way of comparing Christianity with 'Maori gods' or atua comes from Patterson. He says Maori knowledge of human and non-human beings was traditionally seen as coming from a divine source (deities). This was the model of the kinship group of parents, Ranginui (Sky father) and Papatuanuku (Earth mother). ${ }^{229}$ Here is an explanation about their eldest son Tane regarding Cody's contention that, 'Tane is the canoe, Tane is the person.' Rather than a personification of Tane as deity in the tree, which might be seen as tracing the relationship of a devotee and a deity, the link is much more familiar. It is a kinship relationship that is placed before the canoe. That is why Tane is acknowledged as being the father or ancestor of the forests. Before a tree is felled to make a canoe, Tane is acknowledged. That is why Cody correctly notes that Maori see themselves as descendants of atua (deities). ${ }^{230}$

Another way to see the relationship of Tane in the tree is one of sacredness, reverence and respect towards the tree. Some trees were used as platforms where bodies were put to dry out and skin to fall off. The koiwi (skeletons) were then taken down and buried in caves. Such trees gained mana which added to their mauri and they became even more revered. It was the relationship between the people and the tree that was revered, rather than the tree being worshiped because Tane dwelt there.

Another example in my lifetime comes from Pakeha world values. A burial ground for settlers was in the path of an inner-city Wellington motorway and so was dug through and the bones deposited in some large common graves with new grave markers. Roses were planted nearby and the memorial garden named after one of the early settlers. To me, the values seems at odds with the environment. Any reverence for the dead seems to go when progress deems it necessary to dig up graves. Sacredness and respect seem lacking. When travelling though this area I usually say a karakia acknowledging the dead and asking them to rest easy. And this seemingly emotionless attitude of Pakeha values that does not spare its own dead, extends to Maori burial sites as well. Another expressway is planned for the greater Wellington district and it goes through another burial ground. Proponents of the expressway say it is only a Maori burial site and that should not impede progress. I wrote a letter to the editor of the local paper pointing out that many Pakeha settlers were also buried on the tribal land there as a koha (gift from the heart).

\footnotetext{
${ }^{228}$ Naida Pou-Glavish 2010: Maori Television, programme Tautohetohe, screened 22/09/2010

${ }^{229}$ Patterson 1992, op.cit. 102.

${ }^{230}$ Cody, op.cit. 99.
} 
At a time when New Zealand makes a national holiday of Anzac Day honouring Pakeha and Maori soldiers dying in Turkey during World War One, more reverence could be shown to those buried back home. This would establish a common New Zealand value rather than a public holiday.

\section{Functioning as a value}

Cody's further point that Maori tikanga is not to be confused with faith leads me to compare the two. From what we have already seen, that tikanga can be interpreted as functioning in a larger perspective, it could be seen in an Aristotelean way of releasing a thing's purpose. I mean that humans, by being open to connections with other forms of life, can put to one side their selfish needs, for a greater purpose. A contemporary Indian mystic said that "Everything takes on its meaning." ${ }^{231}$ By this, I believe he meant that there is co-relationship between humans and the world and philosophy is the science of asking what type of relationship that is. A philosophy for New Zealand needs to ask and debate that question.

I can best illustrate the meaning of tikanga by expressing it as a value. To be engaged in searching for the function or the 'tika' in appropriate actions, is to be actively engaged in valuing. For example the tikanga of the hosts speaking first on the traditional meeting ground of the marae, carries the function of making the manuhiri (guests) welcome. To do something 'tika' is to do the appropriate action. This can be compared favourably to Aristotle's Nicomachean Ethics where a relationship is drawn between the action taken by the agent and the practical reasoning which led up to it.

"Thus deliberation or planning terminates with the identification of individual things and circumstances in the context of action and can be considered complete only at the time of action." ${ }^{232}$

A virtue ethics model advocates that the value behind the action is what matters, in my example of the marae, acknowledging the mana of the occasion, respect for the coming together. Representing well the mana of the host people also values the collective reputation that these people have earned from following the model of their ancestors. The same courtesy is shown to the visitors whether they be kin or not. But there is a subtle difference between showering the visitors with praise and representing your tribe's own mana. A Maori proverb says the kumara does not tell of its sweetness, "kaore te kumara e korero mo tana mangaro. ${ }^{233}$ The value here is that if your reputation is intact, by and by it will become obvious to all. If not you are just boasting. Whakawaewae wha - get yourself four feet." Do something really impressive. ${ }^{234}$

\footnotetext{
${ }^{231}$ A De Mello, Methods and Practices of Anthony De Mello: Praying Body and Soul (New York, The Crossroads Publishing Company, 1997), 36.

232 Miller 1983, op.cit. 31 (Nicomachean Ethics N.E. 6.8. 114a 26-27).

${ }^{233}$ T Karetu, Maori Proverbs. Revision of a work by A.E.Brougham and A.W.Reed (Auckland, Reed Methuen: 1987), 65.

${ }^{234}$ Ibid, 8.
} 
Thus a practice of tikanga relies on values of unselfishness, hospitality and giving, all summed up in manaakitanga which goes much further than being hospitable. A Maori proverb or whakatauki says it's best to treat everyone as a god as we cannot tell when we are in the divine presence:

'Kai ana mai koe he atua; noho ana ahau he tangata.' 235

A comparable example of the relationship between gods and humans comes from the Indian Vedas:

'By human exertion Brhaspati became teacher of the gods. By human exertion Sukra was elevated to the position of the demon prince's teacher.

There is no end to human effort but it allows us to exhibit some characteristics of divinity.' ${ }^{236}$

These tikanga are all attributes that must be cultivated, hence Patterson's assessment of these values to be seen as 'virtue ethics.' Aristotelean logic is that practical reason moves towards action. In his Motion of Animals Aristotle describes reasoning that involves means and ends.

"I need covering; a cloak is a covering. I need a cloak. What I need, I have to make; I need a cloak. I have to make a cloak. And the conclusion, the 'I have to make a cloak,' is an action. And he acts from a starting point. If there is to be a cloak, there must necessarily be this first, and if this, this. And this he does at once." 237

Let's make this comparison of tikanga and faith more explicit. Cody follows his statement about the dissimilarity between tikanga and faith with his talk of Maori 'deities.' So a more fruitful comparison should take in account the role of deities and faith, especially Christian faith. Cody's point of comparison is that faith is not earned or even acquired by birth or gaining knowledge. It is a spiritual gift. By his talk of Maori 'deities' he implies Maori have the wrong beliefs or that such beliefs need to be subjugated under a Christian cosmology. His attitude of 'wrong beliefs' is unhelpful as Christian cosmology is not comparable to a Maori worldview. Belief is a Christian term and is to be contrasted with Plato and Aristotle views on belief and knowledge that I discussed earlier. It was seen in that discussion that belief can change while knowledge can always make an account of why something is known. Holding onto a belief can lead to dogmatism where a position or viewpoint is defended despite not being able to provide an account of why something is so. Dogmatism demands belief or blind faith rather than a rational account as Plato stated. Cody later goes on in his book to note that some Maori appear to be able to reconcile the holding of belief in Maori 'deities' with Christianity and notes this occurs where Maori karakia are fused with Christian prayer.

\footnotetext{
${ }^{235}$ Karetu c.f. Patterson 1992, op.cit. 64.

${ }^{236}$ Chapple, op.cit. 110.

${ }^{237}$ Miller 1983, op.cit. 31 (Nicomachean Ethics (N.E. 701a 17-22).
} 
My example is a common hui opener:

He honore he kororia ki Te Atua, He maunga-a-rongo ki te whenua, He whakaaro pai ki nga tangata katoa.

'Honour and glory to God who is a listening mountain of the land it springs from, Good thoughts towards all people.'

The opening and closing stanzas owe more to a Christian biblical style, in that a monotheistic God deserves reverence and invites followers to extend this to each other as human divine sparks. This is the Christian prayer. The middle stanza incorporates the land as a living entity that has a whakapapa (connection) or a kinship relationship with humans as a listening mother. My example is a more traditionally styled karakia fused with Christian elements.

Cody sees karakia as invocations to find the right formula for a demand to be met. Christian prayer, he sees more as petitioning and not seeking to control God. ${ }^{238}$ From my study of Christianity, Cody's definition of prayer, as talking to God, is the ideal but not the day to day gritty variety. Some biblical prophets implored Jehovah to deal harshly with their enemies ${ }^{239}$ or moaned of their plight. ${ }^{240}$ Bible commentators explain such prayer as control, as confined only to the Old Testament writers because the love of neighbor had not yet been announced by Jesus in the New Testament. However even Peter, the patriarch of the early Christian church as chosen by Jesus, was not above seeking to control the results, when he rejected an invitation in a vision to eat ritually unclean food. This was despite God identifying himself in the second invitation as making the request! ${ }^{241}$ This vision was taken as an example of an admonition by Jesus to Peter to, 'love thy neighbor as thyself.'

Peter also challenged Jesus to prove his identity when the apostles spotted a ghost walking past their boat who claimed to be Jesus. Peter's prayer was that if that was so, then Jesus should enable Peter to take a walk also. ${ }^{242}$ So karakia as mediation to find the right balance and Christian prayer to seek a favourable outcome do share some common ground.

\section{How to reconcile ideologies}

Although Cody's comparison between Matauranga Maori and Christianity may be helpful as a way of ranking cosmologies, it is ultimately a judgment by one system of another. But because of this unfamiliarity with concepts, it can be of more help to look at the relationships being expressed in the worldviews and see what this says about values. ${ }^{243}$ I have done just this by comparing the Christian values as stated by Cody with Maori concepts. Now I will show the application or distortion of these Christian values in the New Zealand setting.

\footnotetext{
${ }^{238}$ Cody, op.cit. 99.

239 Psalms 139:19 or Jonah 4:3.

240 Book of Job.

${ }^{241}$ Acts 9:13-16.

242 Matt. 14:28.

${ }^{243}$ Patterson 2000, op.cit. 14.
} 
A social historian, Pearson says although missionaries came to convert Maori to Christian principles and values, the reality was missionary agency was intertwined with colonial political interests. Rather than seeing missionaries as protectors of Maori or colonial agents, a broader view is that they were all things to all men. ${ }^{244} \mathrm{He}$ is referring to a philosophical pragmatic approach that was adopted by some missionaries who tried to reconcile Christian ideals with being part of a colonial settlement. They were to seek unity for all people as God's children and model love of neighbor while also living and practicing the superiority of European ideas, religion and technology. Holding an attitude of superiority means others are inferior and valued only as uncivilized natives. This is a negative concept of seeing people only in your superior terms. It needs to be abandoned if we are to have harmony between Maori and Pakeha value systems. Rather, there needs to be an acceptance of diversity. Love thy neighbour should encourage seeing 'all the world as your relation,' as the nineteenth century Indian philosopher Vivekananda preached.

One example of superior ideology was in the colonial view of education. Symbolism involves making a grand gesture of support but not actually following it up with any practise of the values of sharing and caring. The missionaries said schools needed to be established to 'educate' the tribal people through 'native schools.' The government's 'Native Schools' aimed to show the superiority of colonial ways as symbols of progress. ${ }^{245}$

Maori educationalist, Penetito, says Maori had already established houses of learning (whare wananga) that operated into the early 1800's and had adapted Pakeha tools, such as books to supplement oral memory, along with pre-contact chants, skill games and carving. He says Maori establishment of nonmissionary schools, was recognition that education was a way to advance materially and culturally. Penetito says the schooling offered by the missionaries was not the same thing as education. Pakeha wanted to mould Maori to a Pakeha mindset, their own image. He says the history of Maori schooling reveals this as a history of failure of the system to educate Maori students in both worlds. It was much more than a choice of the language of instruction: it was education in the values of Europeans. ${ }^{246}$

A cross-cultural comparison can be made here. India was another colonial outpost of Britain that was targeted for re-education.

\footnotetext{
244 Pearson, op.cit. 44.

${ }^{245}$ L Tuhiwai Smith et al, Myths \& Realities: Schooling in New Zealand (2 ${ }^{\text {nd }}$ Edition), (Palmerston North, The Dunmore Press Limited, 1995), 38-42.

${ }^{246}$ Penetito, op.cit. 131.
} 
In an address to the British Parliament in 1835, Lord Macaulay said,

"I have travelled across the length and breadth of India and I have not seen one person who is a beggar, who is a thief, such wealth I have seen in this country, such high moral values, people of such calibre that I do not think we would ever conquer this country, unless we break the very backbone of this nation, which is her spiritual and cultural heritage, and therefore, I propose that we replace her old and ancient education system, her culture, for if the Indians think that all that is foreign and English is good and greater than their own, they will lose their self esteem, their native culture and they will become what we want them, a truly dominated nation." 247

This intention to break the back of the Indian native was the same colonial intention in New Zealand. Where Britain only partially succeeded because of India' size and rural nature, the task was easier in New Zealand's case. When the Maori population was at its lowest ebb at around 40,000 in the late nineteenth century as a result of Pakeha disease and land-loss, most Maori were in the rural areas, subsistence existing on the remnants of their own tribal lands. They could still live a semi-traditional life with their own tikanga (rituals). Part of this re-education was The Tohunga Suppression Act 1907, which outlawed the practise of Maori philosophy. It was the most outward of punitive acts that celebrated Pakeha-ness over the degradation of a functioning Maori world-view. The Maori epistemological markers were erased in colonial society and Maori were expected to forget. ${ }^{248}$ An elite Maori group emerged with their new Pakeha concepts in the fields of science, health and the humanities. They became members of parliament and used that influence to apply Pakeha medicine to an ailing Maori patient. ${ }^{249}$ As many Maori still followed 'ritenga Maori' (Maori practices) and consulted tohunga to keep them in balance with their environment, the new elite of the Young Maori Party were prominent in support for the outlawing of tohunga. The Act was repealed in the 1960's but by then the damage had been done. Maori had moved from the rural areas to seek employment in the cities from the 1950's onwards where the influence of Pakeha and Maori values were in competition. The mixing and in some cases, the watering down of Maori values in inter-racial marriages will be discussed in the next chapter but the attractions of city life had a downside for a traditional Maori world-view.

Here we can see where the values in Christianity became distorted from the company it kept. The colonising of New Zealand from the nineteenth century onwards bought with it the twin ideologies of Imperialism and Christianity and although they had different agendas, both clashed with a Maori worldview. Said has written that Imperialism is a belief in superiority expressed as 'us and them.' It is also described as ascribing derogatory values to others and then 'othering' people. ${ }^{250}$ Pearson says colonialism was about migration and control and a useful analogy is the core and the periphery. As colonialism is about relations between societies, in New Zealand's case it was between Britain (the core) and tribal Maori (the periphery).

\footnotetext{
${ }^{247}$ Record of British Parliament 1835, Minute on Indian Education, 345-361. http://www.encyclopedia.com/topic/Thomas Babington Macaulay.aspx accessed 6.14pm 24/2/2012.

${ }^{248}$ Moon, op.cit. 10.

${ }^{249}$ King, op.cit. 334.

${ }^{250}$ E Said, op.cit. xiii, 9.
} 
White settler colonies such as New Zealand, Australia and Canada, began with sporadic resource gathering, limited settlement and then mass settlement. The core (Britain), through a treaty gained control of the periphery or colonial outpost. ${ }^{251}$ The inducement for settlers was land and thus conflict with the Maori values of kinship and living in harmony with the environment began. Here also the distortion of Christianity became apparent. The values were hard-pressed, when one Pakeha ideology through its colonial extension was expected to protect and facilitate the settler's interests of land acquisition, while the ideology of Christianity was meant to seek unity and love for both Maori and Pakeha. It was the admonition to 'love thy neighbour' that lost its value. Justice can be described as 'love distributed' and care as 'applied love.' It is a way of socializing respect for each other. ${ }^{252}$

The colonial work ethic was structured around the concept of time. It was a hard taskmaster. The time structure was only relevant to those who had jobs. A communal work attitude, as favoured by Maori practices was not valued. Individual self interest replaced the welfare of the tribe. In rural areas Maori had been able to retain a different work approach as regards time, because the weather and seasons dictated when things were done on the farm, in the bush and fishing in the inland and coastal waters. The living practices still valued the kinship life of the tribe, splintered and landless as most tribes were. All this changed upon coming to the city.

Henare can demonstrate the tangled path of Christian values. He is a Maori writer who has researched Maori society at the time of the major colonial settlement in the nineteenth century. He says it has been an enduring historical belief that the beliefs the missionaries propagated, shaped not only the minds of most colonists but more importantly, were assimilated in the minds of Maori in the pre-large scale settlement stage where biblical terms for governership (kawanatanga) and rangatiratanga (chieftanship) were translated from the everyday Maori language into the treaty document. ${ }^{253}$ Following this line of thought, some Pakeha writers have wrongly decided retrospectively that Maori knew they were signing away their way of life, their rangatiratanga. But this account is challenged. Henare argues for the view that pre and post-Treaty Maori were still in control of their rangatiratanga and Matauranga Maori (authority and authenticity). He says the reverse is true, that Maori religion as culture, subsumed Christianity ${ }^{254}$ and he quotes from Maori language texts that Pakeha historians have not accessed or understood which he says illustrate the depths of Matauranga Maori. ${ }^{255}$

This revisionist view shows how contested is any discussion about values brought by the settlers and what was actually practised in the new environment. Henare says it could also point to the ongoing influence of mana and hau (respect and the spirit to carry it) of contemporary Maori to reinvigorate the models of the ancestors who are credited with choosing to engage with Pakeha and living on in today's descendents. ${ }^{256}$

\footnotetext{
${ }^{251}$ Pearson, op.cit. 29.

${ }^{252} \mathrm{~K}$ Clements, Honouring The Other: The quest for respect, equality and small goodnesses in Aotearoa New Zealand (Dunedin, The Religious Society of Friends in Aotearoa New Zealand, Te Haahi Tuuhauwiri: 2010 ), 21.

253 Henare 2003, op.cit. 221-222.

254 Ibid, 244.

255 Ibid, 20.

${ }^{256}$ Ibid, 85-93.
} 
And that mana is a bigger concept than power and authority: it also includes aroha and whanaungatanga (kinship) where there is reciprocation. ${ }^{257}$

By this aroha is meant, that acceptance of love, sympathy or affection entails an obligation to the giver. But this can only happen between people who have similar values and understand the reciprocation. Some Maori have not been brought up with Maori tikanga or values and no longer relate well to this reciprocity. They are having to learn this as a concept through the education system rather than in the kinship group where the values are more naturally nurtured and obvious. And many Pakeha have no concept of the two way street that this sharing is meant to occur in. While Maori usually set a place of honour for guests at the function on the marae and sometimes even forgo protocols to allow English to be spoken in ritual whaikorero (alternating speeches), the value of reciprocity is usually not practised by Pakeha in return.

Maori elders are not usually given seats of honour on University or Council boards or such institutions. They have to compete for space in the public gallery when the community gathers to celebrate. What does all this mean for finding harmony between Maori and Pakeha values?

This means that contemporary Pakeha need

"...to refrain from unilaterally setting the terms of reference in Maori-Pakeha interactions" and engage with "... a willingness to understand the partner's point of view, the partner's world-view, the partner's values." 258

For Maori, reciprocation means sharing their traditions. Sir Peter Buck, the Maori anthropologist, said the traditions of the Maori are the traditions of New Zealand and so belong to the Pakeha as well as Maori. ${ }^{259}$

Sadly this moemoea (vision) is yet to be realized for the majority of New Zealanders as the Maori traditions have rarely been shared. A Ngati Porou kaumatua, Aorere Riddell says there is no biculturalism from the Pakeha as the term bicultural means Maori have to learn to be Pakeha. ${ }^{260}$

Cody has said that Christianity and Maori worldviews were similar in valuing the dignity of each person and having a basis of aroha in life. ${ }^{261}$ Patterson argues differently. He says deep down Maori tend to view the world and their place in it, in ways that are radically different from typical Pakeha ways. ${ }^{262}$

\footnotetext{
257 Patterson, 1992, op.cit.148.

258 Ibid, 10.

259 Ngata \& Buck, Na To Hoa Aroha: From Your Dear Friend, Correspondence 1925-1950. Edited by M Sorrenson. Three volumes (Auckland, Auckland University Press, 1986-88), 1/179.

${ }^{260} \mathrm{M}$ Ip, Being Maori Chinese; Mixed Identities (Auckland, Auckland University Press, 2008), 149.

${ }^{261}$ Cody, op.cit. 96.

262 Patterson 1992, op.cit. 15.
} 
This is a reference to kinship with all creation, animate and inanimate as well as metaphysical concepts such as a mauri or life force vivifying everything.

\section{Vested interests}

I have shown that the Christian values of the settlers, was just one factor in colonisation. There is a relationship between the philosophy of a society and the vested interests of those who hold the power in that society. ${ }^{263}$ Pearson says the cultural attitudes and values of British tutelage shaped settler ethnic identification between majority and minority groupings and also class relations within the settler colony. The Imperial link of the British Empire dominated the social classes in its colonies and the production of export staples. As settler control of colonial institutions was established, Britain's core was forced to concede political independence.

Key to these points is that the settler society and their descendents

"...... believing in their own cultural and/or racial superiority, established a set of policies and practices that not only sustained a system of differential allocation of resources and privileges, but also sought to encourage or force ethnic minorities to discard their own culture and accept that of their colonisers." 264

My father's generation was an example of discarding Maori language in the face of punishment for speaking it at school. Dad said he didn't teach us the language at home because he thought it would not be useful to us children and it was going to die out anyway. Kuia, Mihipeka Edwards wrote a book about her experiences of getting caned for speaking her native tongue in the school grounds and growing up trying to hide her Maori-ness. ${ }^{265}$

Pearson traces the settler attitude of superiority to the present day. He says because dominant groups don't have to reflect on the settings because they are familiar, they are taken for granted. It is only in unfamiliar settings like a marae or where Maori autonomy still operates in a more private surrounds like a Maori home, that Pakeha ethnicity requires self-reporting or verification. This, he says, explains why Pakeha go in for terms such as 'Kiwis' or 'New Zealanders' when they explain themselves overseas.

I see this Pakeha trait as leaving out the Maori-ness of New Zealand, the local context by which the uniqueness of being a New Zealander acquires meaning. Historian, Michael King said the term Pakeha was relational to Maori and as such, a birth right to be celebrated. ${ }^{266}$ And Pearson says there is no need for Pakeha New Zealanders who have emigrated here, to feel as if they have to cut off all affiliations with their country of origin to belong in New Zealand. He thinks a response of saying they don't know who they are in the New Zealand context, is evading the issue of Pakeha dominance. ${ }^{267}$

\footnotetext{
263 Durie, op.cit. 54.

${ }^{264}$ Pearson, op.cit. 31.

${ }^{265}$ M Edwards, Mihipeka: Early Years (New Zealand, Penguin Books, 1990), 18.

${ }^{266}$ King, op.cit. 516-519.

${ }^{267}$ Pearson 2011, personal communication.
} 
This one-sided dominance pervades New Zealand society throughout government and private institutions. In education, a Maori response has been the introduction of Maori language as the medium of instruction in pre-schools, primary and secondary schools and wananga (tertiary). However the remedy for harmony is the concept of sharing rather than separate development. For this to happen there must first be an attitude of openness to sharing and a desire to find common values.

It is perhaps placing too much weight on Christianity to account for many of today's values when New Zealand is said to be increasingly secular according to Census responses to church attendance. ${ }^{268} \mathrm{~A}$ survey of New Zealand values in 1989 found that less than $20 \%$ of the population had an active involvement in religion. ${ }^{269}$ Pacific Islanders and Maori made up two thirds of the church attendees. ${ }^{270}$ This suggests Christian values correlate to cultural values.

The days celebrated as New Zealand holidays are also an indicator of Anglo/Christian values. Christmas, Easter, Good Friday, Anzac Day, Queen's Birthday weekend all reveal what heritage is valued. For a country that prides itself on giving everyone a fair go, the sole inclusion of Waitangi Day shows how fair and far it goes. It has taken over one hundred and sixty years for a Maori event to be unofficially celebrated each year and that is the beginning of the Maori New Year, Matariki. New Zealand has still to officially encourage other ethnic celebrations such as the Dwali Festival from India.

Additional support for the relationship between religion and values is forthcoming. While New Zealanders increasingly describe themselves as secular as measured by organized religion, there has been a marked increase (75\%) in belief for either a personal god or a 'life force.' It is said that an increasing belief in sin and the devil may be linked to the soulless-ness of science and technology. ${ }^{271}$ But my argument up to this point perhaps shines a light on how that soul was lost. Colonial values had a direct bearing on how New Zealand was viewed by Britain and then negotiated over, then settled and this chapter is focusing on Pakeha values and their effect on Maori values

Patterson tries to explain the colonial mindset by saying New Zealand philosophy traces to British and European, through to Arabic and Greek via Socratic skepticism. ${ }^{272}$ From these views comes the framework for the Biblical command to the first human parents to multiply and subdue the natural world. By extension individualism is associated with utilitarianism and self interest is seen as rational. ${ }^{273}$ Skepticism is noted as a value which utilizes the scientific rational approach and questions everything. Quine, a twentieth century philosopher, is credited with proposing that pragmatism is rationality. But Patterson says testing every theory for counter-examples to find a false instance, is not appropriate for taking a values approach.

\footnotetext{
${ }^{268}$ Statistics NZ, 2006 Census data. Total number of Christians dropped 5\% from 2001 and 25\% more people said they had no religion than in 2001.

${ }^{269}$ Gold \& Webster 1990, op.cit. 63

${ }^{270}$ Webster, Spiral of Values: The flow from survival values to global consciousness in New Zealand (Hawera, Alpha Publications, 2001), 107.

271 Ibid, 168, 191.

272 Patterson 1992, op.cit. 11.

${ }^{273}$ Nettleship, op.cit. 219-220.
} 
An ideal may only rarely be realized, but may still be acceptable as an ideal if the cases in which it is realised are important. Many of us treat each other as means but that's no reason to reject the ideal, that we should treat each other as ends. ${ }^{274}$

My argument is that skepticism is a resting place for reasoning but not a dwelling place. In Chapter Three and Four we look to find a New Zealand philosophy of common values. Starters will be Kantian ethics which give high priority to respect for all persons, ${ }^{275}$ and the Pakeha obligation to achieve understanding of their Maori partner to understand contemporary Maori values. ${ }^{276}$

Philosophers like Patterson are at pains to background their views about Pakeha in a philosophic manner, an arms-length objective stance. He is not saying that all Pakeha were or are like the more unsavoury distortions from colonial history. But he is making the point that there was a definite European world-view, as seen before in the Roman Empire, that was part of the colonising and where it failed to adapt to the Maori environment, it had a much less chance of becoming 'tangata whenua,' people infused by the land.

I believe this European worldview is not a cultural view as it is too broad a term. Rather it is ideological. Many countries have been affected by the ideologies of Colonialism and Imperialism through Christianity and the wealth that was exported through the exploitation of resources.

This colonial worldview described by Pearson, normalised settlers' actions to move onto tribal land with the support of the military, first from Britain and increasingly through settler militia. Parihaka is an example of the utilitarian ethic of 'my land' turning into land greed and despite passive resistance, the village of Parihaka was ransacked in 1881. Many Taranaki iwi were deported to the South Island and jailed. The peace and love preached by Christianity was practised by Maori and met with violence by colonial forces. ${ }^{277}$ This native resistance prefigured Ghandi's doctrine of 'passive resistance' against British colonial forces in India in the twentieth century.

As this is an examination of Maori and Pakeha value systems and not an account of history, it is relevant to take an example of the residual effect of colonial forces. Buchanan's story about the Cape Egmont lighthouse reveals Maori and Pakeha values in action. Persistence and ingenuity was shown by the tribal leaseholders, who for seventy-four years retained a small piece of their confiscated land. But the Crown and settlers used lies and dishonesty to deny the Parihaka descendents even eighteen acres of their former land. The articulation of settler values also changed over that time.

"In the nineteenth century, Maori of Taranaki had been described in terms of excess. There were too many of them, they had too much money, too much land and too much power. They were wasteful rather than provident and careless about the future. These statements overlooked the extensive, well-fenced and tended cultivations and herds of stock that Maori retained around Parihaka."

\footnotetext{
274 Patterson 1992, op.cit. 40.

275 Ibid, 10.

276 Ibid, 15.

277 Buchanan, The Parihaka Album (Wellington, Huia Publishers, 2009) op.cit.
} 
In 1881 Crown troops tore down those fences and destroyed the crops and houses because they were impediments to progress. In 1952 farmers and government officials revoked the lease of the Cape Egmont land because of the absence of fences and that there were weeds on the property. The original farm land and settlement of Parihaka had its fences pulled down. The 1952 farm was re-confiscated because it had no fences. Whose values had changed? This story emerged from the Taranaki report of the Waitangi Tribunal in 1996. It showed that colonization was not a thing of the past, but more than that, the sacking of Parihaka had become a commemoration of a value system that still held fast to the teachings of Taranaki elders, Tohu Kakahi and Te Whiti o Rongomai.

A proverb of Te Whiti is translated as:

'The bird startled has flown, only the quiver of the bough remains.'

"We are the quiver- their descendents whom despite all their pain and hurt and feelings on injustice, never taught us to be bitter, vindictive or take revenge but on the contrary - Give Glory to God in the Highest, Peace on Earth and Goodwill to all Mankind." 278

Thus settler land greed was aided by the military and enshrined in the justice system that, as we found in the beginning of the chapter, took over one hundred years to recognize the Treaty agreement by which peaceful colonization was first made possible. The idea of Maori justice has also been a slow burning fuse in more contemporary times because the accumulation of injustice against Maori has now become too big an issue to ignore. Land and resource hearings since the establishment of the Waitangi Tribunal in 1975, have gathered pace. The values of Maori patience (maia) and forebearance (aroha) have mingled with a measure of Pakeha values of fair play and pragmatism. This pragmatism was even accepted by the Waitangi tribunal's first judge, Eddie Durie, who said it was accepted that the government could not afford to recompense Maori tribes for land loss at today's dollar values. Maori would have to accept a much lesser amount and the land compensation was to be limited to current Crown-owned land only. As government policy, no private citizen's land could form part of any treaty settlement. The plan was that as land came on the market in areas where there were claims, it would be bought and put in 'land banks' for treaty settlement. The outcome of this in value terms is that justice was not to be redistributive, that is, what had been unlawfully taken would be taken back and redistributed amongst the descendants of the original owners. It was also not to be compensatory justice, where goods or money in lieu of the property taken are given back. It was symbolic justice, a token acknowledgement of the economic and moral damage that had been done.

Commentators have noted that the total New Zealand government spend on Treaty of Waitangi settlements has barely raised a percentage point for any one year of Gross Domestic Product. It is poignant to note that the tribunal can only make recommendations to government and many governments have cut back recommendations. ${ }^{279}$ The legislation that guides settlements can also look only at actions by the crown, where it can be shown it did not uphold the justice of its own law, backdated to the signing of the treaty in 1840 .

\footnotetext{
278 Ibid, 183-191.

${ }^{279}$ The National government of Muldoon had a conservative view of Waitangi Tribunal recommendations.
} 
Very few claims have been rejected, so this means the New Zealand government as the descendant of the British and New Zealand colonial governments, has been found guilty as charged. As far as a value judgment can be made, as successive governments benefited at the time of settlement up to the present day from the profits of colonialism, then it seems just that the current New Zealand Government should pay the compensation. A former judge of the tribunal, Joe Williams, recently said on television that the mix of Maori and Pakeha sitting on the tribunal had enabled a stable structure to cope with the huge expectations of Maori claimants and the huge fears of some of the Pakeha population. No-one is claiming that the tribunal's model is a Maori one, rather it was born of Anglo parentage as a court of enquiry in a country not its own. It was offered as a political 'quick-fix' to appease a Maori renaissance of the 1970's that demanded justice and civil rights for Maori.

Injustice has been steadily growing in the civil area, as Maori now dominate the prison population. Lawyer, Moana Jackson, in 1988 presented a report on the New Zealand criminal justice system recommending a separate system needed to be set up. He said it was obvious the British-styled model was not working. He advocated a move away from Pakeha concepts of individual responsibility to a Maori value-based one of collective responsibility. It was based on the concepts that we discussed in the first chapter such as whakapapa (interconnection), whanaungatanga (kinship), mana(authority), tapu (sacred), aroha (responsibility), manaakitanga (showing respect) and rangatiratanga (self-responsibility).

Jackson says these Maori values are excluded from New Zealand criminal law and so:

"....offenders are alienated from the victims of their crimes and from the criminal justice authorities; families and other communities are prevented from sharing the responsibility for criminal offences committed by their members; and perhaps worst of all, offenders are unlikely to have the appropriate sense of shame, are unlikely to have a positive attitude towards putting matters right between themselves, their victims and the authorities, and are likely to develop an entirely inappropriate sense of worthlessness." 280

In this last chapter I have outlined some essential values that Pakeha settlers brought with them to Aotearoa/New Zealand. By back-grounding the worldviews that gave rise to these values, I hope I have put them into the context of their New Zealand setting. My main point has been that, although the initial contact with Maori was not violent, the seeds for dissent had already been sown in the cultural viewpoints of the whalers, sealers, traders and missionaries. It could also be seen that the Maori openness to the unknown, that had seen the ancestors journey from Hawaiiki-nui, Hawaiiki-roa, Hawaiikipamamao (large homeland, extensive homeland, far off homeland), was an value ingredient in the welcome laid out to the Pakeha. The ideals of the Pakeha were not lived up to in the mass settlement that followed. The next chapter is about what sort of new values came about in the mixing of the two worlds of the Maori and the new New Zealanders, the Pakeha.

${ }^{280}$ Patterson 1992, op.cit. 153. 


\section{CHAPTER THREE: MAORI AND PAKEHA VALUES INTERACT}

This chapter looks at the interaction of Maori and Pakeha values and sees them as seeds for unique New Zealand values. A Kiwi truism says values are revealed when you get to the sharp end of things. It is sometimes expressed as you find who your friends are when you are in need. When things are harmonious in life, a person may not be aware of the value system they are practising. But when something goes wrong in a relationship, such as an argument, it is then that what is personally valued as an ethic to live by comes into focus.

In this chapter we focus on four areas:

$1 \quad$ Competing value systems of Maori and Pakeha

2 Resource claims: the moral and legal issues

3 Inter-racial marriage and the effect on values

$4 \quad$ Surveyed beliefs by New Zealand Values Survey 1989

\section{Competing worldviews}

New Zealand is waking up to its past of broken treaty promises and has begun travelling on a road to reconciliation, with some restorative justice. As the legacy of the settler values has largely been an assimilation of Maori culture into non-Maori ways of doing things, it's meant that common values have had to be sought in legal arguments by both tribal claimants and government representatives before the Waitangi Tribunal, as well as by other government agencies and local bodies. Debates about practical solutions to land and resource loss by Maori; high rates of imprisonment of Maori; and inequitable outcomes in education and health for Maori have caused a rethink for some New Zealanders. I believe you can judge the values of a society by the way the most vulnerable are treated.

For Pakeha, the recognition of restorative justice and the desire to belong to this country has also sharpened conceptual tools. Some unique New Zealand values have emerged.

".....in order to enter into meaningful and caring relationships with the natural world we have to learn to earn environmental mana peacefully and cooperatively, following the path of peace and generosity rather than the more familiar competitive paths." 281

\footnotetext{
${ }^{281}$ Patterson 2000, op.cit. 24.
} 
A path of Pacific philosophy is not one of competition but instead a sharing and openness to restore a balance that recompenses, restores and not just with a monetary value. ${ }^{282}$ This recompensing needs to come from an attitude of remorse for past damaging actions of humanity. Use of Maori values, such as kinship or reciprocity in areas like government foreign policy, might arrest or even reverse the trend of New Zealand's diminishing foreign giving.

Patterson has recognized that a different sort of philosophy has been shaped by Pakeha New Zealanders that is different from the predominantly European cultures that settled. Culture has been variously described as: "The intrinsic value of society; synonymous with civilization; the tools, customs and institutions of social groups." ${ }^{283}$ Culture is also all the material and spiritual values created or being created by society in the course of history. ${ }^{284}$

Historian, Jamie Belich, says Maori had quite an influence on colonial Pakeha and they "helped each other invent their substantive collective identities...the two peoples made each other." ${ }^{285}$

He makes the interesting point, that there was a unique social mobility in colonial New Zealand that allowed for the adoption of selected elements of other class lifestyles without losing your own. I believe he is talking about Pakeha class mobility, where majority values were practised. In our discussion about Maori values and their interaction with settler values, Maori mobility, as a valued worldview was mostly downhill. This was despite individual exceptions of crossing culture and class lines, such as people like Miraka Szaszy and her Dalmatian father. ${ }^{286}$

Michael King, another historian, has even suggested that because of this inter-active role, Pakeha have earned the right to be seen as people of the Treaty, 'tangata tiriti,' and a second indigenous people. ${ }^{287}$

Patterson says New Zealand Pakeha philosophy is "... rarely articulated with any precision but none the less a very real and valuable philosophy to the Pakeha." 288

This doesn't say much, just that Pakeha philosophy is helpful to Pakeha as you would expect. As a person with an Irish mum, I know she and her family practised an Irish Pakeha philosophy which owed a lot to a rebellious Catholicity defining its identity against Protestant English heritage. They had a strong kinship tradition mixed with a fierce individuality.

282 New Zealand foreign aid was $0.29 \%$ of Gross National Income in 2010, a slight decrease from the previous year. The United Nation's target is $0.7 \%$. Source: NZ Herald Dec 14, 2010, Paul Harper.

\footnotetext{
${ }^{283}$ Runes, op.cit. 88.

${ }^{284}$ Saifulin \& Dixon, Dictionary of Philosophy (USSR, Progress Publishing, 1984), 94.

285 J Belich, Making Peoples: a history of the New Zealanders (Auckland, Auckland University Press, 1996$), 296$.

${ }^{286}$ Szaszy, op.cit. 5

${ }^{287}$ King made this comment in a Sunday Star-Times essay, 'A vision for the millennium,' 2000. Source: Interview of King by Terry Locke, University of Waikato. https://education.waikato.ac.nz/research/project/item.php?id=118 Accessed 25/2/2012 5.17pm. The comment later appeared in The Silence Beyond: Selected Writings by Michael, (Auckland, Penguin Group (NZ), 2011), 40.

${ }^{288}$ Patterson 2000, op.cit. 8.
} 
That's what I have too. If I can articulate the values of that philosophy, I don't really understand why Patterson thinks Pakeha are reticent about it. To me everything about living in New Zealand shouts this out. Of course this philosophy is helpful to Pakeha, it's just taken for granted. It's all of the dictionary definition of culture and more.

But the home-grown values are not the same as the immigrant root-stock, as New Zealanders who return to their countries of origin find out. Is it not they who have changed by absorbing the values of their adopted country, as much as the practices changing in their country of origin? My point is that values quickly reveal a change in a world-view, as they are included in a culture. Values are revealed in how we receive and respond. That's how I would take the comments of Patterson and Belich and King about the interaction between Maori and Pakeha.

A dictionary meaning of culture as, '...a system of values and ways of thinking peculiar to a society,' backs up my point. ${ }^{289}$

That suggests there was an evolution, something new in thinking that has metaphorically, sprung from the land. In the first chapter I outlined how a Maori worldview links to the land through the concepts of whakapapa, whanaungatanga, mana, tapu and so on. Patterson admits this is what makes Maori 'tangata whenua,' people not just related to the land but a part of it. So by extension, when Patterson says there is a distinctive Pakeha philosophy, it must have been influenced by a Maori world-view in the most positive sense. This is my positive thesis. I see my Pakeha philosophy as reflecting Christianity and Anglo-Celtic cultural values and interacting with my Maori worldview. As worldviews are naturally articulated in day to day value interactions, I claim this is where we can see Maori and Pakeha values at work.

Is there something different about Maori philosophy that explains not just its evolution, but the difficulty that Pakeha have had in understanding it?

Patterson compares the problem to that of feminist and postmodernist philosophers faced with skepticism from a philosophy of vested interests. A philosophy usually reflects the interests of those who hold power in the society which produced the philosophy. So he says, belief that philosophy can deliver abstract, universal and impersonal truths is difficult to prove. ${ }^{290}$

I see impersonal truths as the way we look at the world. If we have differing value perspectives, a way to resolve them is to select those views more conducive to harmony.

Patterson does just this in his two books, Exploring Maori Values (1992) and People of the Land (2000), in supporting the case for a Maori philosophy that can be understood by Pakeha. He believes Maori philosophy is capable of revealing an ethical tradition through narratives. ${ }^{291}$ These narrative traditions are also contemporary, in that while the philosophical ideas they express may have changed over the years along with those of Europeans, the ideas are distinctively Maori.

\footnotetext{
${ }^{289}$ Bunnin \& Yu, op.cit. 155.

290 Patterson 2000, op.cit. 8.

${ }^{291}$ Patterson 1992, op.cit. 182.
} 
Here traditional does not mean ancient. This Maori thought presents a model of harmonious interdependence based on ".... the idea of kinship of humans with the natural world." 292

This universal kinship appears analogous to the Vedic utterance: 'The entire world is your relation (vasudhaiva kutumvakam). ${ }^{293}$ This universality is expanded on in the 'oneness' of the Indian philosophy of the Advaita Vedantans. In the introduction to the thesis I quoted Swami Vivekananda that all religions have the goal of realizing God in the soul. ${ }^{294}$

This Vedic 'relationship,' between all existence in the world is a helpful synthesis to promote values to live in harmony. Relationship was shown in Chapter One to underpin the Maori concepts of whakapapa as connection and whanaungatanga as kinship. Maori and Pakeha are encouraged by Patterson to make their peace with the land in which they live. Seeing the natural world as tapu or sacred makes it clear that humans have a good reason to treat other creatures as ends in themselves, which is a Kantian ethic, rather than a means to an ends.

The eighteenth century German philosopher, Kant is credited with advancing ethical relationships between human beings but for my thesis, produces a limited view because it neglects nature. Descartes excluded creatures from human kinship, believing non-human creatures to be automatons. Maori philosophy sees creatures and the environment as ends in themselves and part of the kinship link with humans through Tane, the common ancestor. This can be contrasted with the Judaeo Christian concept of humans dominating the natural world. In Maori philosophy, creatures carry the mana or prestige of their ancestors and so respect must be shown. Killing them for food is only justified for human survival and then with no more harm than is strictly necessary. ${ }^{295}$

Fitting in harmoniously with this Maori worldview means a person can enhance their standing in the land and earn 'soft' mana rather than continue the colonial way of 'hard' mana, that of taking by force. This is a pacific philosophy, a way of becoming people of the land. ${ }^{296}$

'Soft' mana is caring. It can mean responding to others or the environment, with gestures or little gifts that recognise that all life is a free gift that we do nothing to earn.

'Ahakoa he iti, he pounamu.'297 It is the thought behind the offer that is the gift rather than the content of the gift. This is the concept behind the giving away of the first kete (flax kit) that is made, because Tane, the kaitiaki (guardian) of the forest is being acknowledged. It is also why kaimoana (seafood) is a community resource where 'soft' mana is facilitated in the gathering and distribution by kinship ties.

\footnotetext{
292 Patterson 2000, op.cit. 15.

293 J Shaw, Swami Vivekandanda as a philosopher (Kolkata, Ramakrishna Mission Institute of Culture, 2004 ), 17.

294 Ibid, 8.

295 Patterson 2000, op.cit. 16.

296 Ibid, 131-133.

${ }^{297}$ Maori proverb translated as 'It may be small but it is greenstone.'
} 
Before I can discuss how to apply the philosophy and reveal the unique application of Maori values in a New Zealander context, I must address a major impediment to the harmonizing of values. It is in the area I referred to in the previous two chapters regarding a Maori worldview of the past. I showed that a tradition of following the ancestors' actions revealed in narratives, could be seen as imitating a virtuous or ethical precedent. ${ }^{298}$ The interaction between mana as an authority carried out with aroha, means an obligation must be met at some time. This is utu, the pursuit of mana to maintain a dynamic balance. ${ }^{299}$ It is a helpful way of understanding a Maori view of the past in regards to today's tribal claims over traditional lands and fisheries. What some Pakeha may regard as a preoccupation with the past, could more helpfully be seen as today's descendants wishing to restore the mana of their ancestors and provide a future resource for coming generations. And remember that includes Maori and non-Maori, as most Treaty settlements include gifting of ancestral land to public ownership. ${ }^{300}$

Utu also applies to gift giving, but unlike warlike exchanges, the mana goes principally to the giver not the recipient. That is because human agency is required to plan for future recipients, at times far into the future. It requires both aroha as a wise and far-seeing love and an appreciation of mana to imbue a gift with tapu, a divine quality. An attitude able to perceive this divine gifting as coming through the actions of the ancestors, is seen as measure of an individual's healthy functioning in the Maori world. ${ }^{301}$

The actions of the ancestors are also seen as wise stewardship for successive generations to reciprocate. An aspect of the reciprocal nature of mana is shown in displays of hospitality that obligate a response. In some cases such as an unplanned event like a tangihanga (funeral), the bereaved family will not spare any expense to feed the mourners because their mana or social standing is involved. After the usual three days or so of visitors, a lot of food is consumed. Much effort comes from the locals who volunteer catering services and oversee the tikanga (functioning protocols) of the marae. Neither the visitors nor the whanau pani (bereaved family) are charged for the hospitality as that would demean their mana to reciprocate. The concept of aroha ki te tangata (human compassion) instead combines with whakapapa (connection) and whanaungatanga (kinship) to produce a value of koha (a gift of the heart). Mourners donate money (typically in an anonymous envelope) while locals give of their time. If it is a rural area, koha can also be killed animals or farm produce. In the case of my father's tangihanga, we gave the marae people the koha of the visiting mourners plus our whanau koha (family donation). ${ }^{302}$

Because of the escalating costs of meeting the practicalities of living and dying in the Maori world, some whanau like my cousins levy a set amount amongst their families when they go to tangihanga. This way, they say they can give some assurance of support to the bereaved family and also plan their own finances.

\footnotetext{
${ }^{298}$ Patterson 1992, op.cit. 183.

299 Ibid, 122.

${ }^{300}$ Ngati Whatua gifted part of Bastion Point; Ngati Tuwharetoa gifted National Park.

${ }^{301}$ Maori proverb: 'Ehara i te mea no inaianei te aroha, no nga tupuna tuku iho,' translated as, 'Love is not just of the present but handed down by the ancestors.'

${ }^{302}$ The introduction of GST as a government tax measure in the 1980's meant givers were encouraged to put an amount to their giving if they wanted to claim it as an expense. It also meant marae trustees had to declare koha as monetary value (income) rather than heart value. The marae was also required to supply GST receipts to givers, eliminating the previous anonymity of donors.
} 
But without knowledge of this value philosophy regarding mana and gifting, some Pakeha do not reciprocate. They have different values. The example I have given of attending functions at marae like tangihanga, is sometimes a case for different values where the dynamic balance of mana does not operate. Non-Maori visitors may have a rudimentary understanding of koha as a donation where the 'heart' is left out of the definition. Sometimes a few coins are offered in a sealed envelope in exchange for a banquet of lavish hospitality and marae accommodation. The concept of koha has even been institutionalized, with Maori providers of hospitality being told by government departments how much will be paid for 'hireage' of marae facilities. Usually it is based on per head costs. ${ }^{303}$

A proper understanding of the mana of gift exchanges is needed. The pounamu proverb quoted before, about the intention of the gift applies here. Also what needs to be remembered is the spirit involved in gift-giving, the reciprocity that connects a value with mana (authority), mauri (life force) and hau (gift). ${ }^{304}$

There are other examples of the different value systems between Maori and Pakeha worlds relating to hospitality and use of resources.

The contrast can be seen at times where there are ostentatious displays of wastage, such as bakeries and supermarkets throwing out uneaten food into the rubbish because it won't keep overnight or because of hygiene regulations. A philosophy of sharing, of kinship, of interconnection would make the moves to redistribute food to needy families or even composting banks rather than see wastage. To a limited extent this redistribution is happening, through food drop offs at places like the Home of Compassion soup kitchen or the Night Shelter. There are now even a few shops where food with expired use-by dates is given away free. But these are isolated examples of the wastage from a consumer society and there is little New Zealand cultural awareness of the need to become people of this land by harmonizing use of resources. A remedy is for people to practise Maori hospitality, to share more, to not recklessly covet the seabed for oil exploration, to appreciate the Garden of Eden they live in and earn 'soft mana' through reciprocating. Hospitality also acknowledges all the vulnerabilities we share as human beings.

'Te rongonui o te taniko,

kei roto i te whiriwhiri noa,

mau tonu tona ataahua.

The beauty of the taniko,

is that there is more than one pattern.' 305

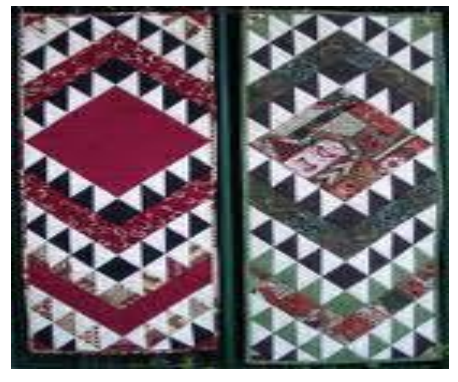

A taniko pattern

\footnotetext{
${ }^{303}$ When I worked for a government department, I received a daily allowance. I was expected to make a koha of my own to the marae I stayed at and claim the allowance when I returned. No receipt was required. This allowance was much less than the cost of motel or hotel accommodation and food. A two value system was in operation, mine and the government's.

${ }^{304}$ Raerino, op.cit. 37.

${ }^{305}$ Taniko is type of woven work. Source: Jackson, op.cit. 157.
} 
The relationship between reciprocity and hospitality also promotes peace.

It is a positive aspect of utu (reciprocity) that can be seen in the treaty settlement of the Ngati Whatua tribe on the Auckland peninsula. ${ }^{306}$ Most of Auckland city is built on Ngati Whatua land, but it was the taking of one of the last tribal areas at Takaparawha/Bastion Point that inspired its occupation in 1978. The ensuring tribal claim saw much of that land returned, along with a cash settlement. The Waitangi Tribunal recommended that Ngati Whatua be given repatriation for loss of the 283 hectare Orakei Block. Crown ownership of 44.8 hectares of this block was to be returned to tribal hands and management vested in a joint tribal and Auckland City Council body. Three million dollars was also awarded to the tribe in compensation to rebuild the tribal structure. A debt of $\$ 200,000$ for Housing Corporation homes built on confiscated land was also forgiven. It could be seen that in an act of utu, the tribe agreed to share a large part of the land returned to the Auckland City Council, where it remains as a park for all.

This Maori concept of reciprocity is not just for Maori as first custodians of the land but is extended to all people. Some might expect Maori to put restrictions on what little land is left but that's not the case, rather the converse is true. For example in the quest to establish Te Araroa, a walking track down the centre of New Zealand, many permissions were needed to cross private land and link public tracks. The author says tribal authorities like Tainui and Tai Tokerau gave the trail mana by agreeing to host walkers and provide Maori guides where the trail crossed tribal boundaries. At the time of publishing (2002), ten percent of the trail still had to be negotiated through private or leasehold property of the South Island high country. ${ }^{307}$

I have previously referred to a Maori comment that righting one injustice shouldn't create another. ${ }^{308}$ This was a reference both to the need for treaty settlements to be what the country can afford and that they should establish some tribal equity for future descendants. Here is an example of a modern day Maori exercising rangatira or chiefly virtues as ethical precedents for New Zealanders to follow.

But first the issue of responsibility for the actions of history needs to be ironed out. Here differing worldviews between Pakeha and Maori also show up in attitudes to responsibility. Maori lawyer, Jackson, says one Pakeha approach is that nobody, individual or group takes responsibility for a wrong, especially if nobody can be shown to have caused the wrong. A Maori approach might be to find out how to rectify the situation. If the wrong occurs under someone's sphere of mana, then that individual or community accepts responsibility, even if the wrong is not caused by them. To arrive at an equivalent collective responsibility, a Pakeha worldview insists on causal control as a condition of acceptance. ${ }^{309}$ The New Zealand government has become the defacto collective conscience on behalf of Pakeha. But I believe harmonizing Pakeha and Maori values is both a collective and individual responsibility just as holistically, the well-functioning of the whole is dependent on the well-being of the parts.

\footnotetext{
${ }^{306}$ Waitangi Tribunal Ngati Whatua Report

${ }^{307}$ G Chapple, Te Araroa: The New Zealand Trail, (Auckland, Random House: 2002), 6-12.

${ }^{308}$ Waitangi Tribunal Muriwhenua Report, 15.

${ }^{309}$ Patterson 1992, op.cit. 150.
} 
Thus the many instances of shady land deals, as well as outright government confiscation of Maori land as at Parihaka in Taranaki suggest:

"... a more ethical future starts with a more ethical past, the sort that might be found in intimate histories, in crooked little family portraits." 310

A remedy suggested so that New Zealanders can earn 'soft mana' and enhance their standing in the land, is that of a step by step process of communities finding out and acknowledging how their current land was acquired. A tribe that does not have its mana recognized, either through court justice or community respect, is a problem for all New Zealand as they cannot exercise collective responsibility if they have no mana. A farmer whose lands are ravaged by floods could hardly have prevented it, but perhaps the stock could have been moved to higher ground. This is the Maori attitude to community and the sphere of mana; the community should be in control of its sphere and so be able to be responsible. The mana of the rangatira works like this, as it his or her responsibility to uphold the mana of the tribe. It's like a team sport such as rugby. The individual is the try scorer but the team gets the collective benefit. But a sending off of an individual penalizes the whole team. The captain of the team is analogous to the rangatira. If the mana of the team is badly affected, the captain may be deposed, just so with the rangatira who allows his tribal mana to be stamped on. ${ }^{311}$ All New Zealanders play in teams. Government ministers are sometimes captains.

These examples show a difference between conceptions of collective responsibility in the Pakeha and Maori worldviews. This is borne out in a nationwide study of New Zealand values in 1989, where the majority of respondents was critical of Maori rights and wanted restrictions on Maori treaty claims or abolition of the treaty settlement system. This finding may seem strange but it was older respondents who felt this way with the younger generation more accepting of Maori rights. ${ }^{312}$

I believe this explanation is in keeping with the lack of New Zealand and Maori history that was taught in school to the older generations. And accompanying the ignorance, there has developed a stubborn attitude of holding onto prejudices.

But it's also been said Maori concepts are excluded from New Zealand criminal law and so Maori collective responsibility is not utilized to shame the Maori offenders and be properly involved in restorative justice. This is the concept where damage to the victim and offender is seen as a collective responsibility to restore. Jackson says New Zealand has individual rights but no collective rights. Patterson's view is that the Maori worldview of collective responsibility is linked to the nature of the world:

".....it extends beyond the family, beyond the tribe.....to all living things." 313

\footnotetext{
${ }^{310}$ Buchanan, op.cit. 264.

${ }^{311}$ Patterson 1992, op.cit. 151-153.

312 Gold \& Webster 1990, op.cit. 32-33.

${ }^{313}$ Patterson 1992, op.cit. 154.
} 
I'll use an example to highlight the worldview of collective rights and the connections to a 'living thing,' the Maori language. My father's generation was collectively discouraged by the Education Department from speaking Maori at school and so they saw the language as unhelpful for the future. As a collective they didn't teach it to their children and as a collective, my generation's mana suffered a language and culture loss. I made an individual decision as a young adult in the 1980's to learn Maori language. I was greatly helped by the influence of the world-wide civil rights movement from the 1960's on New Zealand. I, along with others in the New Zealand, took part as a Maori in reclaiming cultural human rights. But under Pakeha-framed New Zealand legislation, only an individual could bring a case of government culpability before the Waitangi Tribunal regarding failure to adhere to the provisions of the Treaty of Waitangi. An individual claim was laid and collectively Maori took responsibility to back this claim. Recommendations followed and the government acknowledged culpability which resulted in official recognition of the Maori language. ${ }^{314}$

But a Maori values approach promotes a collective responsibility to restore damage, and because the philosophy is holistic, Pakeha need to be involved in the healing as well as Maori. Having a government acknowledge the blame perpetrates the idea of retribution and encourages a victim mentality. Some Pakeha feel guilty for the acts of their ancestors while some Maori feel short-changed by the symbolic victory. Some Pakeha also feel they are victims. For both, as New Zealanders, a common path still needs to be found where Maori language can be a birthright for all the children of the future. This would be restorative justice.

Jackson's recommendation is for a different legal system, a Maori justice system of collective responsibility, where it is the community's role to be involved in remedying wrongs committed against it. This has wider implications beyond Maori. The report says concepts of criminal wrongdoing do not differ greatly between Maori and Pakeha, it is just that Maori need :

"... to assert their rangatiratanga (authority) and their own control over the consequences of wrongdoing by their young. That need is part of the indigenous rights of tangata whenua (people of the land) to make their own decisions in a way that is relevant to them." ${ }^{315}$

But it should not be overlooked that the Maori value of utu or reciprocity, that is behind the idea of collective responsibility for a Maori justice system, also has a common value benefit for Pakeha. Instead of the current sentencing goals of retribution, revenge, deterrence and isolation of the offender and some rehabilitation

“.......a Maori system would endeavour to seek a realignment of those goals to ensure restitution and compensation rather than retribution; to mediate the case to everyone's satisfaction rather than simply punish." ${ }^{316}$

\footnotetext{
${ }^{314}$ Waitangi Tribunal Te Reo Maori Report (Wellington, Government Printer,1987)

${ }^{315}$ Jackson, op.cit. 276-280.

${ }^{316}$ Ibid, 277.
} 
Just how a Maori system would meet everyone's satisfaction is unclear, as successive governments have been unwilling to trial it. However its philosophy could follow the precedent of Judge Mick Brown, who in the 1980's, used his reputation as a Maori judge to change some of the ways in which Maori youth appeared before him in Auckland court rooms. He encouraged elders and whanau to support youth offenders and was instrumental in using community facilities, such as marae, to provide the collective perspective that Jackson's report urges. In some cases, the offender worked out the restorative justice as decided by the community. Here there was counseling with the family and also in the community as well.

Implicit in mediation is concern for the victim and the victim's whanau (wider family). The end result would not be necessarily any more harsh or lenient than the current system but the method would clearly be different. I believe a willingness to explore collective responsibility would begin to heal a New Zealand society, that is polarized over the high rate of Maori offending and the inability of the current prison system to cope. A recent report shows that at any one time, nearly four percent of Maori males aged between 20 and 24 are behind bars. And the consequences for the children of an imprisoned parent are harsh. The children are seven times more likely than Pakeha children to follow the parent's path. $^{317}$

The central philosophy for a parallel Maori system recognizes that the cultural suppression of the past and the cultural denigration of the present, are linked in the diminished self esteem of the Maori offender. Maori people need a cultural framework in which to develop mana and ensure respect. The basis is in Jackson's Justice Department report, which drew from all New Zealand. It was compiled over fourteen months with more than six thousand people contributing views. Within this report can be seen a system of justice based on Maori values.

A natural extension of a separate Maori system of justice is a system of education where the concepts of collective responsibility for community correction and whakama (shame) could be taught. Unfortunately while these values may be taught and practised in Maori language medium institutions like kohanga reo (pre-school), kura kaupapa (secondary schools) and wananga Maori (tertiary schools), this reaches only a small percentage of the Maori population. Most Maori children attend mainstream education, where the Maori values that Jackson is talking about, are not taught. I believe these values would have benefit for non-Maori as well, as collective responsibility involves all in the community.

Let's look at another area of the justice system where contemporary treaty claims have been successful in drawing on Maori value concepts.

\section{Resource claims: the moral and legal issues}

Philosophy is most helpful when it explains why things are seen differently rather than concentrating on describing the practices. The interaction between Maori and settler values in Chapters One and Two showed New Zealanders debating cultural issues with a 'what is' rather than a 'why is,' approach.

\footnotetext{
${ }^{317}$ L Gordon interviewed on RNZ National 'Nine to Noon,' Feb. 20. Pillars' report on whanau of imprisoned parents, commissioned by Te Puni Kokiri (Maori Development Agency).
} 
The latter philosophical approach explains the root causes and the relationships involved, while the former describes the appearance.

This was the difficulty faced in the early days of the Waitangi Tribunal . Evidence regarding claims over guardianship of rivers and lakes, revealed the language and cultural difficulties of explaining to local government officials what was wrong with artificially mixing the waters of two tribal entities. ${ }^{318}$

In the 1980's, the Whanganui River Trust Board Maori and the Te Arawa guardians of the Kaituna river said the waters of their respective bodies of water had a spiritual essence (mauri) and changing the flow and using them for sewage disposal was harmful to this essence. It was the inability to understand this information that contributed to a seeming conflict with Pakeha legislation. What was initially lacking was the understanding of the relationships of whakapapa and kinship we learned about in the first chapter, that established the necessary properties for a tribes' kaitiakitanga or guardianship of a body of water. The kinship between the tribe and the resource had to be shown to the satisfaction and understanding of the tribunal members and this learning process continued for several years, over such resources as land, rivers and river-beds, lakes, off-shore fishing grounds, flora and fauna, radio frequencies and the Maori language.

The Maori relationship with nature is analogous with a reference in the Indian Book of Manu to making good the harm caused to non-human creation. In this case, an offering of fruit and flowers was suggested to expiate injury to a tree. ${ }^{319}$ A further Indian saying expresses nature's relationship with humans, one of acceptance. It says a tree will offer itself to the wood-cutter and if it is a sweet-scented tree, it will leave its scent on the axe. ${ }^{320}$

In the case with Maori kinship values, what was required firstly by the court, was the acceptance of the tribe's custodial link between the resource and spiritual values involved. Only then could that relationship be applied to all claimants. After this, only the specific unique relationships between a particular tribe and the environment needed to be researched and proven. This has been a successful movement evolving a New Zealand philosophy from 'what is' to 'why it is.' Now the legal staff involved in environmental issues better understand Maori concepts and from this, the values involved. They have moved from what is said to be happening, to understanding why it is explained in that way. They see the holistic Maori viewpoint and the function of certain values that explain the viewpoint.

On this point, Marsden says the 'why' of the tikanga doesn't change as it is the 'how' that adapts to changing times. ${ }^{321}$ I believe Marsden is referring to the models of the ancestors, which are to be followed if the life of the tribe is to be authentic.

\footnotetext{
${ }^{318}$ It may be helpful for the reader to refer back to Chapter One to refresh the understanding of key Maori concepts. The Maori Language Appendix following the reference section may also be helpful in locating the meaning of concepts.

${ }^{319}$ Book of Manu op.cit. IX. 143. (Phaladanam tu vrksanam chedane japyam rksatam)

${ }^{320}$ A De Mello, A Way To God For Today, (Australia, Christian Film \& Video).

${ }^{321}$ Henare 2003, op.cit. 43-44.
} 
Marsden is describing Maori philosophy in terms of tikanga or function, which explains why a ritual is followed. This is analogous to the Greek view of the Good as the realization of function. The Good of human beings was realised in rationality or reason. ${ }^{322}$

The function of a Maori value such as kaitiakitanga (custodianship) is more than colonial utilitarian values, such as what can I gain from this? Resources, like bush and sea, are seen as more than food baskets. Henare's explanation of hau as a divine gift is a pointer in the context of human functioning or tikanga. ${ }^{323}$ This giving is two way and is another distinctive feature of Maori culture. A Maori dictionary defines hau as breath, wind, vital essence. ${ }^{324}$ It could also be understood as mauri that is actioned. Human action on mauri is an act of giving or 'gift'. Hau also resides in mauri. ${ }^{325}$ In Christian terms, breath or wind was used to describe the 'spirit of God,' going where it willed. Resources are part of this human functioning and are seen as gift from our ancestors because wise stewardship is part of the ancestors' legacy to future generations.

'E hara i te mea no inaianei te aroha,

no nga tupuna tuku iho tuku iho.'

Love is not just of the present,

it is passed down to us by our ancestors. ${ }^{326}$

The nature of the relationship with gift is revealed in Maori language when describing the ' $a$ ' and the ' $o$ ' categories of possession. Temporary possession of a thing takes the 'a' category. This applies to most portable things. More significant possession uses the ' $o$ ' category. A treasured heirloom of an ancestor retains the ' $o$ ' signifier because it is seen that the relationship continues. Henare brings out this point in his discussion of the insight that tohunga, Ranapira was able to give to the anthropologist, Mauss regarding reciprocity. ${ }^{327}$ "Na, ko taua taonga i homai nei ki a au, ko te hau tena o to taonga i homai ra ki a au i mua." Now the valuable which was given to me, is the life force of your gift given to me earlier. ${ }^{328}$

This means the spirit power and vital essence of the person goes with the gift.

Henare places hau (vital essence) along with tapu (sacred) and mana( authority) as keys to understanding the Maori worldview. ${ }^{329}$

\footnotetext{
322 Miller, op.cit. 34: Nettleship op.cit. 219.

${ }^{323} \mathrm{M}$ Henare, Human labour as a commodity, Maori ethical response. In Labour Employment and Work in N.Z. (Wellington, Victoria University, 1995)

${ }^{324}$ Karetu 1984, op.cit. 7.

325 Henare 2003, op.cit. 53.

${ }^{326}$ Maori proverb.

${ }^{327}$ Henare 2003, op.cit. 103.

${ }^{328}$ M Henare, New Zealand today- Future Directions, Philanthropy NZ Seminar (Wellington, Te Papa Museum, 2007)

${ }^{329}$ Tapine 2000 , op.cit. 8
} 
Each term has several uses depending on the context. In a holistic philosophy, the quest is always to seek the balance. There needs to be a balance between compensatory justice and retaining independence.

The Maori Party Minister, Tariana Turia has given a contemporary example of this balance, in saying Maori need to get off welfare benefits in order to achieve their potential. ${ }^{330}$

For Henare, tikanga is the functioning that connects the sacred spiritual realm to all creation. "The most important aspects of a Maori individual's well-being are the mauri (life force), mana (authority) and hau (gift)." 331

Now let us combine these concepts, that coalesce into the Maori value of kaitiakitanga (custodianship), with another value, that of tino rangatiratanga (self-determination). An English language word used to express the contemporary Maori attitude of self determination is sovereignty. The authors of The Handbook of Cultural and Indigenous Methodologies ${ }^{332}$ say this sovereignty is not so much the European nation-State sovereignty over a space but rather, relational to other human beings. Sovereignty here is analogous with welfare. The authors say enabling Maori values, establishes balance in power relations.

If tino rangatiratanga can be so interpreted as to mean the welfare of the people, a contemporary example of this may be found in the Waikato region.

Waikato taniwha-rau,

he piko he taniwha,

he piko he taniwha.

Waikato, the river with a hundred chiefs, one at every bend. ${ }^{333}$

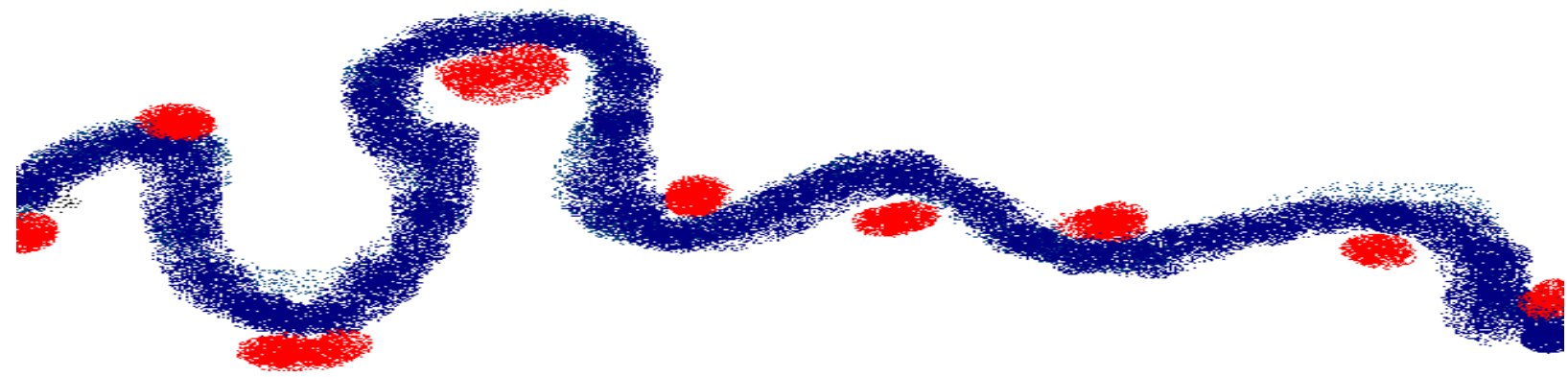

The proverb sums up the caring relationship between the Tainui tribe and their river. Therefore it is natural that the welfare of the people, specifically the Tainui tribe, has been sought through a joint model of management of the Waikato river with the government. Maori values are promoted through the mana of the tribe being recognised to exercise their gifting relationship (hau) with the mauri of the river. In Henare's terms, mana, hau and mauri are operating from a Maori worldview.

\footnotetext{
${ }^{330}$ T Turia, November 1, 2001, press release, www.maoriparty.org.nz accessed Feb 20, 2012, 10.26pm.

${ }^{331}$ Raerino, op.cit.37.

${ }^{332}$ N Denzin, Y Lincoln, L Tuhiwai-Smith, (Los Angeles, Sage, 2008), 440-441.

${ }^{333}$ Waikato tribal proverb.
} 
From a Pakeha government view, the tribe has a guardianship role that complements the agency of environmental protection.

Joint river management was also crucial in securing settlement of the Waitangi Tribunal Tainui claim, and this established a balance in power relations between the tribe and the government. It shows a contemporary emergence and adaptation of Maori and Pakeha values into unique New Zealand settings. What is more, the process of negotiation is capable of resolving conflict.

Penetito says the ethics of Maori philosophy led to an economy of affection and utilization of resources to enable Maori to live in kinship systems. ${ }^{334}$ This model is to be compared to the contemporary liberal economic model based on the utility theory that an individual's consumption of goods and services satisfies human wants and this yields utility. ${ }^{335}$

This economic model is a value system. It is increasingly at odds with 'Green' environmental values and traditional Maori values, that treat the land and waters from the perspective of kaitiaki or guardians, where overfishing or exhausting the soil is discouraged. Pakeha farmers and fishing companies have had to learn the hard way to respect the land and sea. Competition for water resources by farming interests on the Canterbury Plain, that necessitated government intervention, show the lesson is still being learned. ${ }^{336}$ The relentless drive for progress has resulted in production at

the expense of sustainable development.

Over-cropping and intensive farming, along with over-fishing has resulted in such extremes as Cyclone Bola land erosion on the East Coast, major pollution of waterways such as the Manawatu River and fishing quotas to restrict depletion of fish species. Pakeha environmentalists became known as 'Green' because of their support for growing trees. They now support Maori tikanga (functions) regarding guardianship of resources but not from the same philosophical base. Green supporters may value recycling, sustainable development, and healthy food production but the motives are largely utilitarian, that of providing a better future for their children. The deeper Maori motives stem from the intrinsic value of all creation where humans exercise kinship, rather than domination. Ironically, there was criticism of Maori tribes by these environmentalists in late 2009 over Maori commercial logging because of the arrival of the Emissions Trading Scheme. Here tree planting credits are traded for polluting emissions. Generally, sustainable development is an area where tikanga Maori and green ethics are finding common values in a New Zealand environment. But there was no Maori representation at the negotiating table for the Emissions Trading Scheme implementation in New Zealand. There was just the inevitable government policy that followed the New Zealand government signing up to an international convention to reduce carbon emissions globally.

\footnotetext{
334 Penetito, op.cit. 130.

${ }^{335}$ A Bullock et al. In Stallybrass, O \& S.Trombley, The Fontana Dictionary of Modern Thought (London, Fontana Press: 1988), 887.

${ }^{336}$ Dominion Post 2010 May 15.
} 
My view of some common ground between Maori values and contemporary New Zealand practices is perhaps not the reality for most New Zealanders. They may not see the residual effects of colonialism on Maori that necessitate government services targeted at Maori. The ongoing influence of non-Maori ways of valuing life can be persuasive without any other perspectives being offered.

This is the realm of social welfare that sometimes upsets people, who believe we are all born with equal opportunity. Chapters One and Two of this thesis have shown the inequalities that have resulted from the colonising of Maori values. The work of restorative justice can cause division, as we will shortly find out in survey opinions. And this division can be politicized.

A government working for the good of all people needs community acceptance to be re-elected. The minorities within the 'good of all peoples' must fit in with the majority. Here I recall contemporary Western philosophical arguments of Rawls and others, of the need to balance the 'good' with 'justice' as if it was a matter of neutral judgment. We have seen the concept of the 'Good' comes from the legacy of Greek philosophy, as an ideal to be aimed at and these ideals are informed by our values. So what is 'good' is a value judgment. The concept of 'justice' likewise, is reflected in the norms we adopt that support our values.

The lack of common ground between Maori values and some contemporary New Zealand practices becomes very clear when living as a minority in a democracy. In the area of justice, Jackson has advocated a cultural framework which can develop mana and ensure respect for Maori people. I believe these should be the New Zealand values guiding all government social programmes. In dealing with the cultural suppression of the past, the government is tasked with not only restorative justice but also with economic redress for Maori. And it has to do this with the voting approval of the Pakeha majority and within the fiscal constraints of Treasury. That is the reason for the comments I referenced, of the first Waitangi Tribunal chairman who said that Maori settlements must not create another injustice. ${ }^{337}$

Justice has become a matter of what can be afforded. New Zealanders only have to think back to a previous National government policy in 1995 of the 'Fiscal Envelope' where Waitangi Tribunal claims would be fiscally capped at $\$ 1$ billion. After Maori disagreed with this at meetings around the country, the policy was dropped in 1996. Even now in 2012, Maori have been set a deadline of 2020 to settle all Treaty grievances. To achieve this, only historical claims filed before Sept 2, 2008 are being processed. ${ }^{338}$ This is a legacy of the pragmatic philosophy of the Greeks, where man is seen as the measure of all things.

Pragmatism is a philosophy of action directed to reflection where knowledge is guided by interest or values. $^{339}$ Pragmatism is also a method of interpreting ideas in terms of their consequences. To understand the meaning of an intellectual concept, one should consider what practical consequences might result. The sum of these consequences is the entire meaning of the conception.

\footnotetext{
337 Judge Durie, Waitangi Tribunal Muriwhenua Report, op.cit. 15.

338 http://waitangi-tribunal.govt.nz/news/closingdateforsubmissionsofhistoricalclaims/

339 Audi, op.cit. 638.
} 
Pragmatism has been promoted by contemporary practitioners, like Quine and Goodman, who accept reality for its utility - if the operation of the law proposed is useful for man. Quine proposed that a physical object is a postulation, an entity we use to engage in discussion.

"To be is to be the value of a variable." ${ }^{340}$

Tribal leaders have talked of valuing what settlements could do for the tribe and the harmony that would ensue from a more equitable relationship with Pakeha. Valuing and promoting equity has also featured in issues outside of Waitangi treaty settlements. It was pragmatic for the government to appoint Tainui Trust Board's chief executive, Tukuroirangi Morgan as a Crown appointee to the Auckland 'super city' governance board and later, also legislate for a Maori advisory group. This promoted the concept of equity but ran into much opposition within government ranks.

But there are values beyond pragmatism. I have previously quoted Penetito as seeing Maori knowledge as embracing the past, acting on the present and planning for the future. The Maori conception of time is relevant. It can be understood more easily if we visualize a body of people looking forward. The direction in front is called mua. Mua also refers to time which has passed, the time of the ancestors. Accordingly the past, which is in front of the group, is always seen as a reference guide of the ancestors. The direction behind the people is called muri and this is where the unknown future comes from. It cannot be known as the present until it sweeps past the body of people and becomes visible in front as mua.

This conception of time and space is very different for Pakeha. The future is always out there in front and the past is behind. The present is that which is alongside.

For Maori communities in Wellington, this knowledge encompassing the past in the present, is seen in the government funding of Ngati Toa Runanga and Te Atiawa runanga to provide Iwi (tribal) health services. For New Zealanders, who may not know it, this can be seen as the government legitimating, and thereby acknowledging, tangata whenua (native) knowledge. This government action is partly due to the will of the Maori people who have petitioned successive governments since the signing of the Treaty of Waitangi in 1845 for ratification of the Treaty. The benefit is not just to the tribes, because the holistic outlook of Maori philosophy doesn't limit itself just to Maori, it is for all. This Maori outlook enables health services to be provided for Pacific Island people, Pakeha and the growing refugee and immigrant population, for example, at Ora Toa Health in Newtown. Thus valuing Maori tribal tikanga provides a targeted health service and also pragmatically helps the government.

So here we already have an example of a solution, where a Maori value of holism can be for the good of all people, where connectedness is seen as fundamental to relations for all human beings, accessed through a common vision. Authority or influence as mana can be shared. As values are ethical guidelines for behaviour, where the quality of relationship is strong, then the values will carry a strong influence. Kinship and interconnection are two key Maori values that operate in the foregoing example and they are greatly helped by the community nature of the populations being served.

${ }^{340}$ Runes, op.cit. 261. 
I suggest that communities which have a minority status and know dispossession and poverty, are more amenable to standing in each other's shoes and serving the other.

"In those moments we attend to the other with care, single-mindedness and attention." ${ }^{341}$

In another field the government has recognised a different use of the value of mana. In politics the Maori Party has used mana (authority) as tribal cooperation for a base ideology to fuse separate electorate seats into a common pan-Iwi, political power base. Despite going against the Kiwi (Maori and Pakeha) concept of egalitarianism, the arrangement has been accepted as having utilitarian value by the current government. This power sharing is yet to have an effect on mainstream decision making in local body politics and non-state activities. This is despite local councils being creatures of the government and being legally tasked with caring for the needs of local communities.

This is a good argument for Treaty partnership to be integrated into local body political representation. In line with that there are two provisions in local body legislation to ensure Maori representation. This is through the creation of Maori Wards or districts and also through provision of single transferrable voting at local elections. Some local councils have floated the idea of Maori wards with ratepayers but it's proved unpopular and so valuing Maori representation has stalled. ${ }^{342}$

On a national level, the Maori Party working within a government coalition, demonstrates that a utilitarian political philosophy has valued the benefits pragmatically so that it has the governing power to deliver the good. This has seeds for more common goals between Maori and Pakeha community leaders to work together in local body politics, such as the Auckland 'super city' council where cultural and ethnic diversity is high. However this sharing should be at all levels if it is to be more than symbolic. The means are already there within the amendments to the Local Electoral Act, it just lacks political will and heart.

Nationally, political power sharing as Treaty partnership is largely symbolic, as the Maori electorates, with scattered Maori constituencies, are several times larger in area than their General counterparts. Also the number of Maori electorates is determined by an act of Parliament and the action of the Government statistician after every five yearly census. It is currently set at seven electorates. Even total political party capture of Maori seats will not change the power imbalance in a parliament of one hundred and twenty one seats.

Mixed Member Proportional Representation has produced a diverse mix of politicians but the cost to the Maori Party of being in coalition with National has cost it two MPs. That's come primarily because Maori voters believed the Maori Party lost its independence by being in a coalition with the National and Act parties. One of the former Maori Party members is now leading his own Mana party, which signaled racial inclusiveness by the nomination of two high profile Pakeha activist for the party's list in the last election.

\footnotetext{
${ }^{341}$ Clements, op.cit. 17.

342 The Kapiti District Council near Wellington says it is considering Maori representation on all its council committees.
} 
Meanwhile, the Green Party's Metiria Turei is also proving an articulate co-leader and prominent in the National coalition is Hekia Parata, the new Minister of Education. Overall MMP may be good for individual Maori but the fate of the Maori party shows what happens when Maori electorate voters disagree with the policies of Pakeha coalition partners. Nationally and locally, Maori representation is hard work. The Treaty promise of partnership is more symbolic than actual. The real work is done in finding common values in the humanity of those represented between two value systems of Maori and Pakeha.

I think Maori communities have not fully focused attention on local body politics, as historically the national level is where Treaty partnership began and is still focused. Thus local body politics are relegated to a secondary status, and Maori standing for office, represent themselves as individuals, rather than adopting a Maori philosophical platform. Wellington city councilor, Ray Ahipene Mercer demonstrated Maori conservation ethics with his campaign protecting the korora (little blue penguin) but his continued popularity with voters comes from representing all people in the community. ${ }^{343}$

Maori community groups and Iwi (tribal groups) until now, have seemed content to interact with local governance, rather than be issues-driven as with national politics. The Auckland 'super city' inclusion of a tribal leader on its governance board, provides a precedent for looking at common values amongst the diverse ethnicities and races that live, not just in Auckland, but in other New Zealand cities. And while we are talking about hearing the voices of other ethnicities represented on civic bodies, we should consider universities, colleges and such bodies that claim to represent the community.

One common value often overlooked in the diversity of peoples is their humanity.

French philosopher, Jean-Paul Sartre, brought a new ethical thinking to Western philosophy utilising this humanity and focusing on what humans chose to value. Contrary to centuries of Aristotelean thought, Sartre believed the essence of humanity came from the choices we make, rather than from anything we are born with. Making a choice makes us responsible for the actions that follow. Eighteenth century philosopher, Immanuel Kant had said that a rational will was an autonomous or free will, the author of its own choice. This is the Kantian influence on Sartre who acknowledged humans have possibility, and can always do something about their situation despite the socioeconomic and historical conditions that modify that freedom. But Sartre advanced this by saying that free choice was good for the whole nature of man, for humanity. One test of this is that an authentic choice never exploits others. ${ }^{344}$

We can apply this humanism to our current social conditions in Aotearoa. Both Maori and Pakeha and all shades in-between, can make choices not to exploit each other. The Stanford Encyclopedia of Philosophy defines exploitation as to take advantage of another. ${ }^{345}$ Because of the power imbalance exploitation has largely been seen to be on the Pakeha side. Chapters One and Two showed the more negative aspects of this exploitation.

\footnotetext{
343 Personal communication 2002.

${ }^{344}$ Stanford Encyclopedia of Philosophy accessed 22/9/2009, 6-8.

345 Ibid. http://stanford.edu/entries/exploitation/ accessed 22/2/2012, 12.55pm.
} 
The Maori world has been affected by the influence of Pakeha values through an ideology of essentialism, which could be seen to be exploitation of some Maori. ${ }^{346}$ Certain traits have begun to define the identity of a Maori as essential features. The ability to speak Maori language, knowledge of tikanga (cultural practices) and ability to access Maori sources of knowledge are all traits more or less essential to being considered a Maori.

Possession of such knowledge has come to be associated with 'te ao Maori (the Maori world) and it is marked as a contemporary feature of Maori 'wellbeing.' Those self-identifying as Maori with no access to 'te Ao Maori,' are said to have a notional identity, while those not identifying as Maori are said to have a compromised identity. ${ }^{347}$ Defining is also setting limits and so marks out those who have little knowledge of the Maori world. For those Maori unsure of their identity, a more helpful approach may be, how does one 'be' a Maori rather than defining who is a Maori.

While Maori complain of exploitation through Pakeha values, some Maori have begin to voice their own disquiet within their own backyard. A kuia, Miraka Saszy told students at a graduation in 1993 that they could use their degrees to either uplift or exploit their people. She called for a new humanism amongst Maori not based on nineteenth century tradition, but rather on ancient values versed in contemporary life.

"He wairua Maori hou ara he momo tangatatanga i tupu mai i roto i te Ao Maori tawhito me ona tapu, ona ihi me ona wana e taea ai e ia te noho i roto i nga piki heke o te ao whanui." 348

She compared the graduating students to the Maori sentinels of a village, on whose vigilance depended the life and death of the people. Saszy said the sentinels' challenge came down through the ages carrying the spiritual essence of the people. She called on the students to sacrifice something of themselves, ${ }^{349}$ to:

"seek the seeds for the greatest good for all people." 350

\section{Inter-racial marriage}

So how do Maori and Pakeha values interact on a human level and be revealed in actions? Inter-racial relationships have been a feature of New Zealand. Half of all Maori living as a couple have a non-Maori partner and nearly 70,000 New Zealand couples are in Maori-Pakeha relationships. ${ }^{351}$ The relationships may promote common values, a give and take situation - provided they are based on the concept of partnership. A common experience is for one partner's value system to swallow the others.

\footnotetext{
${ }^{346} \mathrm{M}$ Henare, Te Tangata te taonga te hau: Maori concepts of property. Paper to conference on property and the constitution (Wellington: Victoria University, 1998)

${ }^{347}$ Durie, op.cit. 57.

348 Szaszy, op.cit. 7.

349 Ibid, 4-6.

350 lbid,1.

${ }^{351}$ C Archie, Skin to Skin intimate true stories of Maori-Pakeha relationships (Albany, Penguin Books, 2005$), 8$.
} 
One of the ironies of the book on Maori-Pakeha relationships is that most interviewed weren't advocates for mixed marriages. ${ }^{352}$

A better remedy is to share the best values of both, or look to find common roots in traditions that promote shared values. I believe true partnership exists where there is joint approval about important matters.
'Ka tu au ki Huiarau,
Ka titiro atu ki Nukutaurua.
E tu tangata ahau,
E ko Kahungunu.
I stand on my Huiarau mountain range,
I look to the landing place of my waka.
I stand upright and proud,
I am Kahungunu.'

This Rakaipaaka whakatauki, a chant of my Rakaipaaka hapu of Ngati Kahungunu, can be recited before speaking to identify the speaker. This helps me make a link with the people present and also identifies me to them. They can then see if and how I am related to them through family, tribe or location and who we might know in common. Already a common ground is being prepared for us to relate to each other regarding the business at hand.

If you're Irish,

Come into the parlour,

There's a welcome there for you.

If your name is Pat or Jack,

There's a welcome on the mat,

So if you're Irish,

Here's to you

(Popular Irish folk song)

I hail from two worldviews, the Maori and the Irish. On the Maori side, the tribes on my dad's side are Kahungunu and Rongomaiwahine and Te Aitanga a Mahaki. Mum's Irish side hails from County Kerry in Southern Ireland. From the Irish I get strong family values of tenacity, individuality, loyalty and passionate spirituality. From the Maori, I get perspectives, patience and belonging.

${ }^{352}$ T Misa, NZ Herald in Race problems unlikely to be solved in the bedroom, accessed 22/2/2012 1.24pm. 
Marriage above all is about partnership. Patterson says real partnership entails sympathy, empathy, identification, trying to see things from the other's point of view.

"Another way of putting this point from a Maori perspective would be in terms of a concept of balance - the need to meet the partner at least half-way." 353

It's a recurring theme in Maori philosophy

The following examples of inter-racial marriage should be thought of in those terms of partnership. They have been deliberately selected from Maori-Chinese unions, because they represent an increasing Asian demographic of New Zealand that is predicted to equal Maori by $2050 .{ }^{354}$

Monica Thompson-Mercury is the youngest daughter of the Thompson family, born in New Zealand in 1968. She is a mokopuna (grandchild) of Seui-Jung Wong and Hori Thompson. The Wong family emigrated from China in the late nineteenth century. The Thompsons (originally Tamihana) come from Hawke's Bay. Monica is married to a Samoan and shares a house with her grandparents. She says both Chinese and Maori are strong on family values and some form of spirituality.

"Both are strong on ethics, but in different directions. For example, the Maori family, in times of need or difficulty, they pull close together. They're not geared to academic success, but they work for a common goal. The Chinese toil and toil, to be successful, to become comfortable, they want to do well." ${ }^{355}$

Danny Goddard is the son of Nancy Wai-Lan Kwok and George Goddard. Nancy's father was a respected leader in the Wellington community and a supporter of the former Nationalist government of China. Nancy went against her father and supported the Communist China cause and founded the New Zealand-Chinese Friendship Society. Danny grew up surrounded by his mother' siblings and wasn't told about his dad's Maori side until his teenage years. He says up until that point, he had considered himself Chinese because he mixed with and looked Chinese. He says his large physical size set him apart from his Chinese cousins but when he realized he had Maori heritage, he started to get involved in Maori things such as weekly Maori culture club at Ngati Poneke.

"I just joined and nobody turned an eyelid. No one queried my credentials."

He became involved in Maori political activism in the 1980's. He is proud of being Maori-Chinese and knows the ropes in both communities. He has woven both traditions together. Chinese, like Maori believe genealogy ties you together. His wife is Maori. He says not being full blooded Maori hasn't mattered to people, it being more about networks and friendships. He's found if you can show you have Maori ancestry there's no questioning.

\footnotetext{
353 Patterson 1992, op.cit. 10.

354 Statistics New Zealand, Hot Of The Press, Series 5 (Statistics New Zealand, Wellington, October 2007)

${ }^{355}$ Ip, op.cit. 80 .
} 
".....my children, they haven't seen their Chinese family enough and they're not Chinese. They will not be so strong. If they marry out again, that will be lost. There is a sense of sadness whenever I come to think about it. For my children, they have their Maori heritage, but they look more Chinese than Maori." ${ }^{356}$

Danny's experience suggests that Maori values are more accepting than Chinese and this is borne out in another inter-racial example.

Lily Cheong parents' immigrated to New Zealand in early 1900's and became market gardeners in Mangere, Auckland. Lily's first husband was a Maori-Chinese, also the son of Mangere market gardeners. Lily grew up with Maori-Chinese children, who were considered by their Chinese parents:

“...not to be equals...not the same (as pure ethnic Chinese), they were different. I think Maori were much more accommodating... I think they would bring these children more into the extended families and be more welcoming." ${ }^{357}$

The value of acceptance strikes the reader of Lily's story. The attitude of the Chinese parents is much harder than that of the Maori. Perhaps the work ethic was stronger with the immigrants who were more desperate to make a go of life in New Zealand. And maybe they resented the easier approach of the Maori who took time out to go to the beach after a day's work. Whatever the reason, Lilly and the other Chinese children really appreciated that they were accepted as one of the family by the Maori. Conversely, the acceptance by one group didn't mean a rejection of the values of the others. Lilly and others of mixed Chinese-Maori parentage in Being Maori Chinese, seemed to also accept that there was diversity in the values operating. Most grew up able to accept different value systems and the contexts and culture in which they were practised.

Lily's decision to concentrate on Maori empowerment came from her feeling that Chinese culture wasn't dying but Maori was, it was a strategic decision. This was in the 1970's and 1980's at the time of increased Maori agitation for civil rights.

Lily sees a lot of similarities in culture between Maori and Chinese, with good relationships having developed, and so sees no reason for Maori to pick out one group and say they are not welcome. She says the major groups in Auckland; Maori, Pacific and Asian are quite strong and so she sees a 'browning' of Auckland in coming years that will displace the majority Pakeha culture. Lily says Maori-Chinese have added a dimension to Maori education, to Maori industry, to the economy, to being creative. She says the Chinese attitude towards commerce has added value to the Maori community work ethic while also bringing a wider community perspective to the Chinese community.

${ }^{356} \mathrm{Ibid}, 168-174$

${ }^{357}$ Ibid, 129. 
“All Chinese New Zealanders should go back to China for a visit .... because if they don't they would think they're just like Pakeha...they would miss out on accessing a rich culture......it is good to be able to adapt to the Maori, Pakeha and the Chinese worlds, as opposed to not knowing where you are and not sure about where you stand." 358

Respect for an elder's wisdom was also another value common in these Maori-Chinese unions, where the children saw how their grandparents were respected by their own children. Lynell Keung remembers her grandpa's dictum passed on to her by her father that you can work hard now or work harder later. ${ }^{359}$

So these examples show the Maori values revealed in inter-racial marriages with Chinese. Common values between the two cultures were found by some for the betterment of their families, and as some believe, for the wider community. Where there was a willingness to look for shared values, the interracial family found harmony for their children, and more pertinently, for the community.

From the examples quoted, there was no one successful way of realising this harmony: it took an attitude of heart, an awareness that Maori and Chinese had family traditions that valued human relationships. From my experience with Pakeha families, acceptance of a non-Pakeha in-law is a much more gradual, guarded, individual journey. Stereotypical behaviour is expected, usually gathered from second-hand sources. Many is the time I have had people turn down invitations to come to a hangi as they explain they don't like dirt on their food. (A hangi is a steam oven where food is wrapped in cloths and placed over hot stones before being covered under the ground). I've found that a willingness to not take offence and to keep the offer open, is the best value in inter-racial relationships.

Before ending this chapter section, I wish to tell a story to illustrate a point which reveals Maori identity and values. An artist was being interviewed about his work and the question came up, "What is Maori art?" He replied that it was art done by a Maori who was a combination of their ancestry, be it French, English etc but it was art performed in this land of New Zealand and with reference to it.

"And what is a Maori?"

"A living ancestor of all those ancestors before, in relationship with this land."

And then the artist told the interviewer he saw her as a living ancestor, just as he was too. ${ }^{360}$

Commenting on this exchange, I would see that the values are represented in the ancestors and live on in the descendents. As this was a Maori artist talking in New Zealand, I would add that appreciation of Maori art is also included in those values as a reference to the land. And from the artist's other ancestors came an appreciation of non-Maori art, such as painting, opera and classical dance.

${ }^{358}$ Ibid, 138.

${ }^{359}$ Ibid, 106.

${ }^{360}$ Darcy Nicholas. Interview on Radio New Zealand National, Saturday morning 2010, Sept 10 by Kim Hill. 
I venture that the latter art-forms, which have a high status in the New Zealand Pakeha art-world, overshadow the appreciation values of Maori art.

From these examples of personal sharing about cultural values let's now go to the bigger picture to see how New Zealanders see themselves.

\section{Surveyed beliefs or how New Zealanders see themselves and others}

A survey of New Zealand values was undertaken in 1988 of a sample of New Zealanders and followed up in subsequent years. ${ }^{361}$ The author of the 1988 survey's findings defines values as an affective component in all judgments. The survey found common values were formed around such judgment areas and reported them as defining 'kiwi-ness.' Here is a summary of the values found. ${ }^{362}$

$1 \quad$ Family values and sexual morality

People agreed that marriage was not outdated and there should not be complete sexual freedom.

(A traditional Maori view of marriage was of a monogamous relationship. While this was probably true of the ordinary people, for those of high birth or status, polygamy or more than one wife was practised. The reason was to strengthen links between tribes and hapu (sub-tribes); to make peace through the giving of a son or daughter; to demonstrate mana by taking the enemies wives; or to commemorate an occasion where bravery was displayed.)

2 Relationships between people

People agreed on the need for respect and tolerance between people and that violence was not justifiable.

$3 \quad$ Basic human decency and support

People felt the government was responsible for ensuring a decent standard of living.

$4 \quad$ The right to work

There was agreement on increased government spending on employment and job training and the importance of an interesting work as a job quality.

$5 \quad$ National feeling

There was pride in the nation and belief that democracy is the best political system.

$6 \quad$ Value of environmental harmony

${ }^{361}$ Gold \&Webster 1990, op.cit.

${ }^{362}$ Summary in: Webster 2001, op.cit. 121-137. 
There was concurrence that humans must co-exist with nature rather than master nature. But when forced to make a trade-off, only half were willing to pay for this co-existence with nature through increased taxes. The paying group tended to be supporters of the Labour Party, the better educated and people aged 55 years of age and under. Those unwilling to pay included Maori who gave a higher priority to fighting crime. ${ }^{363}$ (I believe this shows the dislocation of Maori environmental values as regards social inequalities.)

\section{$7 \quad$ Belief in an ultimate being}

Three quarters of those surveyed believed in a god or a life force.

But there were also kiwi-ness value conflicts in the following areas:

1 The child in the family

There is conflict about whether parents should always be respected and reflects traditional cultural streams and liberal modernity.

(In this survey, those identifying as 'Maori above all,' were strongest in expecting respect from children to those older than them. I believe this respect for elders was also a Pakeha settler value, but operated within the strict family group. This contrasted with the more communal ethos of Maori. Contemporary New Zealand values have been much influenced by the global notion of individual rights, and the primacy of the individual meets most resistance in those who hold fast to the Maori concept of the whanau. Here individual rights are to be balanced within collective responsibility for the mana of the community).

\section{Social capital}

There was much disagreement about the importance of community organizations, the role of the government to bring order in society, the level of trust in other people and what categories of people make good neighbours. Maori and Pacific Islander were twice as likely to place confidence in community organizations, as their values were based on a relationship with, rather than isolation from, the extended whanau community.

3 Redistribution of wealth

There was conflict about reduction in income differences and a government response to poverty.

$4 \quad$ Work satisfaction

There was clear disagreement on the feeling of accomplishment in a job, with ethnic minorities rating work satisfaction lowest. (This may be explained by the nature of the work being repetitive and lowly rated by society, thus contributing to the social alienation already experienced as part of a minority).

$5 \quad$ Maori rights and the rule of law

${ }^{363}$ Gold \& Webster, op.cit. 5. 
There was much conflict over this area as it could be said that desecration of rights brings into question the sanction against violence and was a failure of relationships between people with the consequent lack of respect. (The rights relate to the Treaty of Waitangi). A large majority of Maori supported Treaty rights and an equally large Pakeha majority were critics. Age also played a part with supporters of Maori rights strongest in the 18-24 age range, with support dropping off with age. Critics of Maori rights were also divided on gender lines with females twice as likely to give support. Educational achievement also featured in the data. Only those in the sample with a university education were likely to give support to Maori rights. ${ }^{364}$

$6 \quad$ Environmental values

As mentioned before, the core values of co-existing with nature were in conflict with concern over increased government spending on environmental protection.

\section{$7 \quad$ Religion}

There was a disparity between the core value belief in a higher power and the value-priorities expressed in everyday life. ${ }^{365}$

For this thesis on harmonizing Maori and Pakeha values, it is useful to see the fit between these values and how those surveyed saw themselves. The writers of the survey were keen to test the historical view that the two races of New Zealand were Maori and Pakeha, so they asked for an ethnic national identity by the following categories: above all I am a Maori; a Pakeha; a European; a Pacific Islander; an Asian; a New Zealander first and a member of some ethnic group second; not stated. Ethnicity was also asked for under the following categories: NZ Maori, NZ European or Pakeha, Other European, Samoan, Cook Island Maori, Tongan, Niuean, Chinese, Indian, Other.

Just under half those surveyed designated themselves New Zealanders, a quarter chose Pakeha, nearly a fifth chose European, six percent chose Maori and one percent chose Pacific Islander and one percent Asian. ${ }^{366}$ Half of the ethnic Maori of the total sample put themselves as New Zealander above all, reflecting the flavor of this thesis chapter, that there has been an accommodation of Maori and Pakeha values with potential for evolutionary development.

Another survey backs up the 1988 New Zealander Values Survey view, that the terms Maori and Pakeha are relational. ${ }^{367}$ The 2009 NZAVS data had 14\% identifying as Pakeha and slightly more (22\%) as European. ${ }^{368}$

364 Ibid, 32-33.

${ }^{365}$ Webster, op.cit. 161-165.

${ }^{366}$ Ibid, 95.

${ }^{367}$ C. Sibley, 2009, Auckland: Manager of New Zealander Attitudes and Values (NZAVS) at the Department of Psychology, Auckland. The survey began in 2009 and surveys the same 6000 people each year for a twenty year period. http://psych, auckland.ac.nz/uoa/new-zealand-attitudes-and-values-study accessed 22/2/2012 3.52pm.

${ }^{368}$ Sibley, op.cit. 1. Why do some people prefer the term Pakeha more than others? 
The 1988 survey said these Maori New Zealanders had very similar questionnaire responses to the mainstream New Zealander culture but those who identified as 'above all Maori' were markedly different in their responses.

While they expressed confidence in the importance of community organizations, their confidence in them lagged behind other New Zealanders. For the 'above all Maori,' there was great insistence on parental authority but more dependence on community responsibility, than the institution of marriage. It was also seen by them that the element of identity was crucial in interpersonal communication and was related to this sense of community. Because of this, establishing one's own identity in a relationship was seen as leading to understanding the other. ${ }^{369}$

This finding seems to be backed up by the 2009 NZAVS data. Those who considered their Maori identity as a core value were much more likely to use the term Pakeha as a positive cultural engagement. ${ }^{370}$

For Pakeha, establishing one's identity did not rate as so important. Here I would contrast the conclusions of Chapter One, where the value of Maori identity is to provide kinship as a relationship to all people and connection with the land, hence the importance of firstly establishing one's own identity in a relationship. The Pakeha identity in New Zealand, discussed at the beginning of Chapter Three, has been shaped by interaction with Maori, but is barely acknowledged publically. I think this is because of feelings of guilt over actions of settlers and little community opportunity to speak about healing.

The silence is also due to Pakeha ignorance of New Zealand's Treaty history. There is also still some arrogance in Pakeha pragmatism that says 'forget the past and get on with the present.' And then there is Maori resentment over the past and an inflexibility to stand in the other's shoes and forgive. For all these reasons Maori and Pakeha differ on the notion that you need to know who you are first before getting to know others.

As a corollary, those identifying as 'above all Maori' do not see children's respect as conditional on parents' behavior, as respect has its roots in the community. This harkens back to the Indian philosophic tradition of dharma, which is seen as the connection between ontology (being) and ethics and religion that maintains society; that teaches and protects. ${ }^{371}$

"The dharmasastras have the important role in the form of presenting before the society a norm of life for all the members, including those who do not belong exactly to their class, because they have other affiliations; thereby moulding the society for securing the ultimate end of life. It may be stated that these texts are practical applications of spiritual doctrines for the betterment of society." ${ }^{372}$

The 'above all Maori,' group emphasis on community roots also reflects the first chapter's Maori values of whakapapa (interconnection) and whanaungatanga (kinship).

\footnotetext{
${ }^{369}$ Webster, op.cit. 121-137.

${ }^{370}$ Sibley, op.cit. 4. Why do some people prefer the term Pakeha more than others?

371 Jha, op cit. 39.

372 Ibid. 20.
} 
The N.Z. Values study concludes that there is a real dynamism in Maori culture that is mixing traditional heritage values with modern values and is much influenced by the material conditions of existence. It says New Zealand's multi-cultural society contains a spectrum of cultural evolution that gives hope for systems of equitable sharing and an increasingly harmonious community.

It says closing the gaps of social inequality must go beyond:

"....mere balancing of the financial books, as if that settles what constitutes the common good...... But the common good in a multicultural society is multiple good defined by multiple worldviews." ${ }^{373}$

The wording almost brings us full circle to the concepts of Maori philosophy that began this discussion. In essence these were whakapapa (interconnections); whanaungatanga (divine kinship); mauri (life essence) and mana (respect, prestige, authority).

My argument has been that within a reinvigorated Maori philosophy, there are the seeds for a distinctive New Zealand born value system that incorporates Pakeha world-views, as we saw earlier in the chapter with Maori-Chinese marriages, and just now with how New Zealanders described their values. In the next chapter, the focus will be on how to resolve differences between philosophical and cultural views through 'discourse ethics.' On the way I plan to state my final arguments that a unique New Zealand philosophy is being formed that gives a 'kiwi' flavor to living in harmony. I draw from the first chapter of this thesis, that Maori philosophy provides the essential 'evolutionary' flavour that takes Maori tradition and reinterprets it in a contemporary setting, such as the many teaching marae at mainstream and Maori universities.

A French philosopher, Ricoeur says the persistence of tradition is due to creative innovation in each new generation that re-imagines the form of life of the people. ${ }^{374}$

In Chapter One I referred to The Book of Manu, which talked of each new generation discovering itself. ${ }^{375}$ Manu also encouraged an 'evolutionary' aspect with its advice for a well-functioning society because it provided for changing circumstances of the society. It said this innovation was essential if the law was to invite obedience of the citizens. An example is given of empowering women to take a second husband during a time of calamity. ${ }^{376}$

\footnotetext{
${ }^{373}$ Webster, op.cit. 195.

${ }^{374}$ Wood, op.cit. 25.

${ }^{375}$ Manu 11.1.in G Buhler, The Laws of Manu (Sacred Books of the East, XXV, Oxford, 1886)

376 Jha op.cit. 18.
} 


\section{CHAPTER FOUR: TOWARDS A HARMONIOUS NEW ZEALAND PHILOSOPHY}

My argument has been that traditional Maori values still survive in Aotearoa/New Zealand as practical guides for everyday living. Maori culture remains dynamic and has shown its evolutionary nature by providing values for such modern institutional responses as the Waitangi Tribunals claims settlement process and education, where Maori language and concepts are taught in kohanga reo (pre schools), kura kaupapa (secondary schools) and wananga (tertiary institutions). Maori values have in turn been adapted (some activists might say subverted) for non-Maori Pakeha contexts, as the iconic sporting haka Ka Mate, the welcoming rituals to tourists, civic Maori language signage and public usage and Maori advisory positions within institutions. At times the alliance between the values of the worldviews is tenuous and an example given in Chapter Three from the survey of New Zealand values, shows that the perception of some people is that the Maori expression of these values is divisive.

The concluding chapter of my thesis focuses on ways through this conflict, where the goal is the betterment of society. My encouragement for this goal can be expressed as the dharma of Indian social science where:

"...just as light and shade do always co-exist so too are the deed and the doer joined together...one creates one's own misery; one causes one's own happiness." ${ }^{377}$

In other words, we are the architect.

Chapter One concluded that Maori values are fundamentally holistic, as has been shown by the critique of Patterson's Pacific philosophy and the views of Maori tohunga (ritual experts). This means the wellbeing of the whole is dependent on the parts functioning well. Society needs individuals to get along. This means the philosophy behind the values is both dharma in the Indian sense of 'that which supports the world,' and whakapapa as interconnection and relationship. Maori values, as I have holistically defined them, cannot be exclusive and limited in scope and application, they are for all.

Say what you will about the Waitangi Treaty claims' process, it is grounded in a certain mix of pragmatic Maori and Pakeha values, that Chapter Two revealed. The view of social scientist, Benhabib, sums up what the previous three chapters were pointing to - that understanding other contemporary cultures is like a conversation. We bring our presuppositions to the dialogue, adjust them in light of the answers of the other and then reformulate another set of questions, and so on. And in line with the thrust of this thesis, I use Benhabib's reasoning as a model, as she argues for cross-cultural studies of the processes of interaction, because she says, there is still very incomplete understanding of how cultures have interacted and influenced each other. ${ }^{378}$

377 Ibid 37.

${ }^{378}$ Benhabib op.cit. 62. 
The historian King agreed, saying Pakeha should be not viewed as aliens who stole resources and gave nothing in return. He said Pakeha culture has changed much from its European origins, with borrowings from words and concepts (mana and manaakitanga), more consensus in business dealings and changes in rites and passages, such as a loosening up of formerly formal funeral services. That's because Pakeha settlers and their descendants have also been affected by what King called 'the indigeneity' or belonging of Maori. ${ }^{379}$ My view on this point is that Pakeha have indeed been affected by the strong affinity Maori still have for New Zealand. This is sometimes more an attitude than a defined practice and some Pakeha have reflected it in the love of the outdoors, and camping in primitive bachs or tents by the beach or bush. At times I think this is more of a reassertion of the colonial mentality, to 'tame nature.' But over the generations Pakeha have learned to begrudgingly acknowledge the call and influence of the land and waters, to call it their home too. It is a different sort of relationship born of a different perspective on history. It's reflected in a little story. When the Taranaki warrior, Titokowaru was defending his tribal land, after a successful skirmish he would look to his mountain and say that the mountain looked tall. When he was on the run and unsuccessful, he would say that the mountain looked small. His success or failure was reflected in his mountain.

"Some days the mountain looked taller. Most it seemed smaller. Today it was slow making up its mind." 380

\section{Educate ourselves}

But how to get differing paradigms together in mutual respect? At one level, this moral conversation is taking place in New Zealand in the redress of historic injustice via Waitangi Tribunal treaty claims. But that is an institutional response on behalf of the people and removed from common talk between neighbours. My goal is more direct. That is to suggest that educating ourselves about the other's values may more likely lead to understanding their point of view. It will also help us to articulate deeply held but elusive prejudices. Values build their guiding character from relationships with others - the environment as a living context and with our human selves. The values lose their authority to guide our lives to the extent that the relationship is deficient: between Maori and Pakeha world-views; with the environment we live, work and play in; and with our sense of self.

Chapter One showed how values were formed through relationship (whakapapa/connection and whanaungatanga/kinship) in a holistic way. Where there has been a two way relationship between the values of a Maori society and a Pakeha society, mutual respect has been forged. Maori believed this respect had been earned by Maori fighting alongside Pakeha in two World Wars. But on return home after the Second World War, the land grants for soldiers favoured Pakeha over Maori. This situation was discussed during a recent documentary about the police raids on the Tuhoe tribe of the Urewera in the hunt for terrorists.

\footnotetext{
${ }^{379}$ M King, Penguin History of New Zealand (Auckland, Penguin Group, 2003), 518-9.

${ }^{380}$ M Shadbolt, Monday's Warriors (Auckland, Hodder \& Stoughton Ltd, 1990), 263.
} 
The raids were seen as the continuation of government oppression with the massive land confiscations of the nineteenth century and the parceling off of confiscated holdings to Pakeha soldiers after World War Two. ${ }^{381}$

Most of this information has been tabled before the Waitangi Tribunal in their hearing of the grievances of the Tuhoe people. Negotiations are continuing between the tribe and the government but justice is yet to be realised.

The treatment of returned Maori servicemen, such as the Maori Battalion, by government has also been referred to as a debt unpaid.

"...the debt of citizenship in our country in terms of recognition of our own tino rangatiratanga remains unpaid." 382

One social thinker has called it, restoring a two eyed vision to what was previously a one-eyed view. ${ }^{383}$ However this reciprocity between worldviews needs to be built on, as one-eyed thinking remains, as evidenced by the New Zealand values survey. Here some people believed respect and tolerance between peoples was necessary but did not consider historical, physical and psychological desecration of Maori belongings merited any modern-day redress such as treaty claims or Maori rights. At least not from the public purse!

My argument is that reciprocity is not limited to just two views, as the Chapter Three examples of being Maori Chinese showed. Lily believed that Maori and Chinese had much to offer Pakeha New Zealanders. ${ }^{384}$ Exposure to a second view can lead to a general openness to other levels, to encompass a worldview of multi-culture. But it begins when that second view meets the other half-way, in a give and take situation. The openness towards many views enables a synthesis of values, so that a new philosophy can be born of the contemporary New Zealand environment. This is where I situate discourse ethics as a communication tool to find common values between world cultures and philosophies, such as the evolving New Zealand Maori/Pakeha blend.

\section{A Discourse Ethics Guide}

My method of using discourse ethics to encourage harmony in the community follows:

- A value is defined as an ethical guideline that aids human behaviour towards the environment.

- A New Zealand value is one performed in New Zealand with reference to the country.

- Tikanga is a traditional Maori value meaning the function or the nature of a thing.

- Tikanga take their value from a holistic philosophy where the well-being of the whole is dependent on the well-functioning of all the parts.

${ }^{381}$ Maori Television, Operation 8 documentary on Urewera police raids screened October 30, 2011.

${ }^{382}$ M Szaszy, op.cit. 10.

${ }^{383}$ Benhabib op. cit. 242

${ }^{384}$ Ip, op.cit. 138. 
- Tikanga is a reference of functionality within the New Zealand environment (of people and things).

- Post-colonial Maori were knowledgeable and flexible and able to be pragmatic enough to adapt traditional tikanga to a contemporary living environment.

- The current Maori generation is a mixture of inflexibility and excessive pragmatism which has weakened the tikanga (functional) value. By this, I mean some Maori have interpreted tikanga as unchanging tradition of pre-Pakeha vintage. Other Maori have either not known or have abandoned Maori tikanga in favour of Pakeha values.

To get clarity at this point, there needs to be education in the philosophy of the history of New Zealand, particularly the interaction between settler values and traditional pre-Pakeha contact Maori values. This can lead to new understanding that:

- Evolutionary ethics take their influence to guide from interpreting traditional values in the light of contemporary innovation in the current environment.

- Maori tikanga incorporate evolutionary ethics by their very nature or function. Some examples are reciprocity in extending hospitality not just to the descendants of Pakeha settlers but also to more recent arrivals, such as refugees or immigrants.

- Where is conflict over norms of behaviour in this country we can ask, "What is the tikanga or function of that norm with reference to New Zealand?" This is in keeping with the holistic philosophy of Maori and also incorporates some of the better pragmatism of Pakeha values.

At this point, posing the tikanga or functional question means, I am asking how this problem is related to me as a fellow citizen and asking what connection or reference does this uniquely have with New Zealand as a dynamic environment.

The reasoning behind discourse ethics is based on communicative action, where rational agreement is possible if we are prepared to back up our special claims by reason or persuasion and not by coercion. This is called practical discourse. To engage in debate is to agree not to exclude anyone or any assertion. To deal with other worldviews outside of mine, I must be prepared to meet the argument half-way and this is termed having a universalistic morality. A local cultural view can be advanced but there must be an openness to question values in the light of rationally justified norms.

- An attitude of 'meeting the other halfway,' is beneficial to open discussion.

- Being able to question my own values enables me to 'stand in the other's shoes.'

- Seeing another perspective encourages commonality or harmony.

- Using New Zealand values and models, like tikanga, is a New Zealand philosophy.

The German philosopher, Habermas, says a de-facto acceptance of norms enables most social interactions. Having difference is alright but a common understanding of the situation is needed that a speaker can back up with reasons. The conditions of the discussion are that participants value sincerity, understanding and reason as principles to live by. 
They need to agree that debating as a way to resolve conflict is a universal concept and valid. A principle of universalization is important because it requires that all affected parties can accept the consequences anticipated, for everyone's interests.

Habermas says values are rooted in culture and have goals but the discourse or conversation is aimed at finding common norms or rules to observe beyond 'parochial contexts.' Some like Rawls advocate 'bracketing' differences to allow for hypothetical agreement and this can be seen as acting strategically. However Habermasean discourse calls for 'moral argumentation' to resolve the interruption, rather than strategic action aimed at influencing the decisions of a rational opponent in order to achieve the agent's own goals. ${ }^{385}$

Here I will expand on a New Zealand example I've used previously. A moral argument could be taking one's shoes off before entering my house, not because you fear what I might do if you don't take them off, or because you expect some advantage if you do. Rather you take your shoes off because you recognize the validity of the rules of etiquette and that taking your shoes off is an appropriate response because of hygiene, not wanting to bring in the dirt from outside. This appropriateness was referred to in the first chapter as a 'tikanga' or doing what was appropriate or functional in the context of the human and physical environment of Aotearoa/New Zealand. I accept that knowing rules of etiquette requires education but in a New Zealand context, I have already shown in Chapter Three, that many non-Maori have already shown it's possible to have a form of life that meets others halfway. ${ }^{386}$

One way to view this conversation, is seeing it as a quest to find norms that restore the damaged life. There may be a helpful analogy here with the Buddhist view of life as 'suffering.' What is meant by this phrase is that human beings become attached to objects, to people and things and expect them to perform to their own expectations. Inevitably there is disappointment, and energy is used to manipulate the situation for one's own ends. This whole process is described by Buddhist philosophy in the phrase, 'all is suffering.'

Buddhist teaching is that this material world is illusory and does not matter. Attachments to beliefs and desires in this world will ultimately let one down and disappoint. Much effort is put into maintaining the object of the desire but the end is the same. To a Buddhist, all this process is covered in the concept of suffering. The way out is to practise non-attachment. ${ }^{387}$

This tenet of Buddhism is of course not universally accepted, nor is it being advanced as such. The analogy is used by me because I find it helpful sometimes to restore my damaged life by seeing a bigger perspective and accepting my part in it. It's my way of getting rid of my prejudices so I can join you in a conversation.

\footnotetext{
${ }^{385}$ S White, The Cambridge Companion to Habermas (Cambridge, Cambridge University Press: 1995), $120-146$.

386 Ibid, 146.

${ }^{387}$ S Radhakrishnan \& C Moore (eds.), History of Philosophy: Eastern \& Western (London, Allen \& Unwin, 1967$) 160$.
} 
In Chapter One, I referenced a Maori proverb about times of peace and war that showed the value of flexibility. ${ }^{388}$ In the current context of restoring a damaged life, the virtue extolled by the proverb could be acceptance - that everything has a purpose and is allowed to happen for a reason.

I see non-attachment as not trying to control the results of my choices, but accepting the outcomes. If I can accept even things I am fighting to change, then I may find peace and harmony.

I take from this Buddhist analogy that this acceptance is what is being asked in discourse ethics. New Zealanders could choose to see contemporary misunderstandings as 'suffering' within society and let go their attachment to beliefs that divide people. In Buddhism, suffering comes from holding on to a perspective and investing it with energy. Non-attachment is the road to freedom.

Stances can still be taken and points of view observed, but there is no longer the determination to hold onto the view at all costs. I see it as not trying to control the result or outcome of our choices. What will probably happen is that there will be an increasing appetite for more perspectives as more choice reveals itself.

\section{Relationship refines us}

One of those misunderstandings is around definitions of what defines Maori and what defines Pakeha, rather than what is common between the two. For me, a way through is to see that Maori concepts are not dualistic but incorporate polar opposites and as King has said, you can't have one without the other. There is a relationship here. An example previously used, is the term hoa as friend and riri as angry, which leads to hoariri being used as a linguistic expression to refer to an enemy. Seeing an enemy as an angry friend may motivate you to remedy the cause of the anger and restore the relationship. And following the 'tikanga' or functional method of examining the point of conflict, we are engaging in a holistic philosophy where the relationship of the parts (you and me) determines the well-being of the whole (all of us).

This functional method I am emphasizing is in line with a philosophic difference between Maori and Pakeha worldviews. A Pakeha view emphasizes a particular part while a Maori view emphasizes the whole. A Pakeha view tends to lead to an attitude of individualism and selfish interest. A Maori view leads to the interest of the whole, which is a less selfish attitude. Here the emphasis on $I$ is on a par with you.

Benhabib's criticism of Habermas' philosophy of discourse, is that rather than universalizing norms in exchanges, such as conforming to a universal brother or sisterhood, participants in discourse should consider what she calls 'concrete individuals' and attempt to stand in their shoes. However she concedes an agonistic struggle (my needs versus yours) has a place in discussion.

\footnotetext{
388 "I nga ra o te pai hei pa, I nga ra o te kino hei kino. In war, settle your disputes by force, in peace, let things be done in a friendly way. G Grey, 1971, Nga Mahi a Nga Tupuna, in A Alpers Maori Myths and Tribal Legends (Auckland, Longman Paul, 1964), 31.
} 
Habermas has a strong universalist position on rationality and morality and defends the modern West as best embodying these values. Understandably he has come in for some criticism from feminists like Benhabib, who point out the shortcomings of universalizing the 'other' in any ethical discourse.

Other critics have said that discourse ethics only works within the context of a particular life and when it is applied between life-worlds, it runs into problems. ${ }^{389}$ My view is that life-worlds can be mutually inclusive and a 'concrete individual' can be bi-or multi-cultural. ${ }^{390}$ A contemporary social theorist PoataSmith says "..... identities are not actually lived as separate entities, hermetically sealed off from one another. One is not simply Maori in one instance, a woman in another instance and a worker in yet another instance." 391

I would see the same circumstances applying to a diverse Pakeha identity, such as the NZ Values survey showed in the self-selection of the categories: New Zealanders; Pakeha; European; Pacific Islander. ${ }^{392}$ There can be many 'life-worlds' for a Pakeha or non-Maori New Zealander.

My view follows what I have been advancing throughout this thesis, that the Maori value concepts of whakapapa (interconnection) and whanaungatanga (kinship and relationship) are all about seeing and finding commonality, rather than difference. It is relationship that is the value. A conversation involving discourse ethics leaves room for relationships with multiple overlapping life-worlds or publics, ${ }^{393}$ such as New Zealanders of mixed ancestry e.g. Maori Chinese, as well as the diversity of identities self-selected in the New Zealand Values Survey. Also there are the many examples given in this thesis of people moving between Maori and Pakeha life-worlds, where common norms have been incorporated from values with different philosophical perspectives. What the people have in common is that their values were assimilated either as part of growing up or else learned in adulthood. The new norms worked out in practice in Chapter Three, have been our thesis working model of how Maori and Pakeha values can be lived in a New Zealand environment.

That we might fail to reach agreement is reflected in the conversation of Maori and Pakeha life-worlds as recounted throughout this thesis. That's because the values we practise are for each of us what constitutes 'the good life,' either as the ideals legacy of Greek philosophy or comparably, models of the ancestors from Maori philosophy. These values are rooted in the culture in which our identities are socialized. Most of the time our social interactions are about the acceptability of norms or rules and our duty to obey them. In legal jargon, the norms are termed, 'matters of justice,' or legal principles. In the New Zealand justice system, Treaty claims and Maori civil rights have been seen in this category. And justice is still to be realised. Behind those rights and wrongs lie our values. To use discourse ethics is to question our values and the norms, by standing in the other's shoes and questioning our 'rights and wrongs.'

\footnotetext{
${ }^{389}$ Hemmingsen, Post-Modern Cosmopolitanism \& Discourse Ethics (Wellington, Victoria University, 2011) 81.The reference is to worlds with a particular value assigned to life.

390 My father and I are examples of this.

391 Poata-Smith, op.cit. 71.

392 Webster, op.cit. 150-151.

${ }^{393}$ Habermas commonly referred to different groups in society as publics.
} 


\section{CONCLUSION}

This thesis has focused on seeking a way through a New Zealand conflict of a cultural, political, spiritual and philosophical nature. The on-going effects of British colonization on an indigenous Maori population have resulted in a culture largely reflecting the norms of non-Maori (Pakeha). My approach has been to attempt a way through the conflict via a discussion of the values that inform those norms. As this thesis is seen through the eyes of a writer of Maori and Irish cultures, the philosophy of Maori values as well as settler British values has been examined.

Along with virtues, I have stressed the relational Maori values of whakapapa as connection and whanaungatanga as kinship. The philosophy of ideals in which they sit is holistic, the whole being dependent on the parts for its well-being. The Maori worldview was shattered by the values implicit in colonization, that of superiority and domination. Habermas has said that our values reflect our concept of ourselves and come from the culture in which we live. ${ }^{394}$ The mixed 'unwell-being' of Maori since the impact of settler values has been sourced in the inequality of the settler norms as shown in this thesis, from the criminalization of Maori that Jackson talks of, to the contemporary land confiscations by government departments, such as the Cape Egmont leased land affair in the Waitangi Tribunal Taranaki report. ${ }^{395}$ Until issues like these are settled, we will not be engaging in a true moral conversation of discourse ethics.

The accommodation of this inequality, seen from a bi-cultural philosophical perspective, shows that Maori and settler Pakeha hybrid values have evolved and taken on unique outlooks, that historians and social scientists have noted. One aspect has been the dynamism of Maori culture, that values establishing one's own identity first before meaningful community interaction can take place. Another cited from the N.Z. Values Survey, was that there was a definite value to balancing scientific progress with spirituality and environmental harmony. ${ }^{396}$ However this balance needs a holistic appreciation that is more present in Maori philosophy. An emphasis on science as progress has dominated a non-Maori worldview, by focusing on particulars rather than the whole. Restoring a Maori worldview of relationships and connections between the parts (kinship and whakapapa) is a new New Zealand way of functioning and using the concept of tikanga.

This thesis has shown that as Maori and Pakeha values rubbed against one another, new norms evolved, such as respect for Maori language as shown publically in signage and ritual. As well there have been new protocols for settling historical Treaty claims. However these institutional responses need to be actioned as individual values for more meaningful change in our lives. Plain talking in local communities has been suggested as a tool to walk in the shoes of the 'Other.' These tools include the introduction of Maori language and related cultural concepts available at several learning levels.

\footnotetext{
${ }^{394}$ White, op.cit. 150.

395 Buchanan 2009, op.cit. 264.

${ }^{396}$ Webster, op.cit. 56.
} 
Learning access for all, could be through free community night classes in bi-culturalism and multiculturalism, business training courses in NZ ethical practices and the use of interactive technology to encourage young people to discover a unique Kiwi perspective in their global world. ${ }^{397}$ I have suggested communities research how their land was acquired, and within that debate hopefully will come a questioning of one's values. But it is not a solo journey.

"Because we exist as individuals only through our membership in concrete forms of life, justice cannot be conceived without some form of solidarity." ${ }^{398}$

To me this speaks of the concept of compensatory justice, because deprivation goes beyond economics to poverty of spirit. This is where people become demoralized. Solidarity also speaks about rising or falling together which is the ethos of a tribal project, as we saw in Chapter One. Today Maori as a community are addressed in government policies such as Whanau Ora, which is about communities being funded to look after their own health needs.

This does not let Pakeha off the hook, as Maori communities are part of New Zealand society and solidarity encourages walking in the other's shoes. Using the 'tikanga' functional model might help us to 'stand in the other's shoes' and look back at ourselves from the other's perspective. This takes compassion and aroha to understand and accept diversity in humanity, the oneness of Advaita Vedanta, the universal of Habermas, and the kinship of Maori.

The Indian concept of dharma has critiqued this solidarity as a goal for the betterment of society with the belief that "righteousness is an independent science of greater importance than day to day administration." 399

Therefore the common thread that binds this thesis is the relationship of the individual to society and the cultural environment of that society. Righteousness is a caring attitude that guides and empowers supportive action. The individual values inform the culture. Maori values promote kinship and belonging through aroha (love) manaaki (hospitality) and utu (reciprocity).

Pakeha values of love, care and hospitality, if they encompass love for all, can connect with Maori values and so come to belong as values of the tangata whenua, as people born of the land.

Above all, tangata whenua are people who value the land because of their connection in relationship with it.

He kanohi kitea, can translate as, "A face seen is an argument understood." 400

I hope the argument I have advanced in this thesis has been understood and that my face has been seen.

\footnotetext{
397 The Mauri Ora programme of Te Wananga o Aotearoa is an example of a free home-based learning resource.

${ }^{398}$ White, ibid, 151.

${ }^{399}$ V Jha, op.cit.1.

${ }^{400}$ King, op.cit. 110.
} 


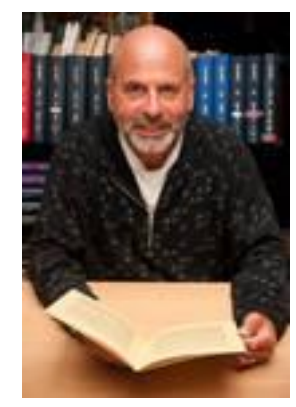

"He toa takitini toku hoa, ehara i te toa takitahi."

My strength is not that solely of myself, it is the strength of many.

(My Kahungunu tribal saying) Piripi Whaanga

Na reira e hoa ma, kia ora tatou katoa. Therefore friends, I wish us all well. 


\section{REFERENCES:}

Aristotle . Nicomachean Ethics, (translated T. Irwin), 1985, Hackett Publishing Company, Indianapolis.

Audi, R. The Cambridge Dictionary of Philosophy: Second Edition: 1995, Cambridge University Press: New York.

Belich J, Making Peoples: a history of the New Zealanders from Polynesian settlement to the end of the nineteenth century, 1996, Allen Lane/Penguin, Auckland.

Belich, J. Making Peoples: a history of the New Zealanders, 1998, Auckland University Press, Auckland.

Benhabib, S, Situating The Self: Gender, Community and Postmodernism in Contemporary Ethics, 1992, Routledge, New York.

Benhabib, S. The Claims of Culture: Equality and Diversity in the Global Era, 2002, Princeton University, Princeton.

Best, E. Maori Religion and Mythology Part 11, 1982, Govt. Printer, Wellington.

Bhartrhari (570 C.E. - 651) Hindu philosopher and poet-grammarian, author of 'Vakyapdiya' (Words in a Sentence) regarded as one of the most significant works on the philosophy of language.

Buchanan, R. The Parihaka Album: 2009, Huia Publishers, Wellington.

Buhler, G (translator)The Laws of Manu, 1886, Sacred Books of the East XXV, Oxford.

Bullock, A. et al. In Stallybrass, O \& S.Trombley, The Fontana Dictionary of Modern Thought, 1988 Fontana Press: London.

Bunnin, N \& J Yu. The Blackwell Dictionary of Western Philosophy: 2004, Blackwell Publishing, Malden, MA.

Chapple, C. Karma and Creativity, 1986, State University of New York Press, Albany.

Chapple, G. Te Araroa: The New Zealand Trail, 2002, Random House New Zealand, Auckland.

Chattterjee, S \& D.Datta. An Introduction to Indian Philosophy, 1939, University of Calcutta, Calcutta.

Clements, K. Honouring The Other: The quest for respect, equality and small goodnesses in Aotearoa New Zealand, 2010, The Religious Society of Friends in Aotearoa New Zealand/Te Haahi Tuuhauwiri, Dunedin.

Cody, P. Seeds of The Word, 2004, Steele Roberts Ltd., Wellington.

Collins, H. Ka Mate Ka Ora: The Spirit of Te Rauparaha, 2009, Steele Roberts, Wellington.

Cox, R \& M Schechter, The Political Economy of a Plural World: Critical Reflections on Power, Morals and Civilization, 2002, Routledge, London, New York. 
Craig, E (gen. ed.). Routledge Encyclopedia of Philosophy, 1998, Routledge, New York.

Cruickshank, G. Io Origins Te Matauranga o te Ao Kohatu, He taonga tuku iho mai a lo ki te Ao Hurihuri, Ancient knowledge of the Living God in Aotearoa, 1998, Graham Cruickshank, Whangarei.

D Datta, The Six Ways of Knowing, 1932, Allen \&Unwin, London.

De Mello, A. A Way To God For Today, Christian Film \& Video, Australia.

De Mello, A. Methods and Practices of Anthony De Mello: Praying Body and Soul, 1997, The Crossroads Publishing Company, New York.

Denzin, N. Y Lincoln, L Tuhiwai-Smith. Handbook of critical \& indigenous methodologies, 2008, Sage, L.A.

Durie, M. Te Mana Te Kawanatanga: The Politics of Maori Self-Determination, 1998, Oxford University Press New Zealand, Auckland.

Edwards, M. Mihipeka: Early Years, 1990, Penguin Books, New Zealand.

Gilligan, C \& J Murphy, Moral Development in Late Adolescence and Adulthood: A Critique and Reconstruction of Kohlberg's Theory in Human Development 23, 1980.

Gold, H \& A Webster, New Zealand Values Today: The popular report of the November 1989 New Zealand study of values, 1990, Alpha Publications: Palmerston North.

Goldsmith, E. The Way: An Ecological World-View. Revised Edition, 1996, Themis Books, Totnes.

Gordon, L. Report writer interviewed on RNZ National 'Nine to Noon,' Feb. 20, 2010. Pillars' report on whanau of imprisoned parents, commissioned by Te Puni Kokiri (Maori Development Agency).

Grey, G. Nga Mahi a Nga Tupuna in A Alpers Maori Myths and Tribal Legends, 1964, Longman Paul, Auckland.

Habermas, J. The Theory of Communicative Action, Vol 1: The Reason and Rationalisation of Society, 1984, Heinemann Education, London.

Habermas, J. Moral Consciousness and Communicative Action, 1990, MIT Press, Cambridge, Mass.

Hemmingsen, M. Post-Modern Cosmopolitanism \& Discourse Ethics, 2011, Victoria University, Wellington.

Henare, M. Human labour as a commodity, Maori ethical response. In Labour Employment and Work in N.Z., 1995, Victoria University, Wellington.

Henare, M. Te Tangata te taonga te hau: Maori concepts of property. Paper to conference on property and the constitution, 1998, Victoria University, Wellington. 
Henare, M. PhD Thesis, The Changing Images Of Nineteenth Century Maori Society- From Tribes to Nation, 2003, Auckland University, Auckland

Henare, M. New Zealand Today-Future Directions, Philanthropy NZ Seminar, 2007, Te Papa Museum, Wellington.

Hiriyanna, M. Outlines of Indian Philosophy, 1968, Allen \& Unwin, London.

Ip, M. Being Maori Chinese; Mixed Identities, 2008, Auckland University Press, Auckland.

Jackson, M. The Maori and the Criminal Justice System, a New Perspective: He Whaipaanga Hou. Part 2, 1988, Department of Justice, Wellington.

Jha,V.N. (ed) Dharmasastra and Social Awareness, 1996, Sri Satguru Publications, Delhi, India.

Johansen, P. The Maori and his Religion in its Non-ritualistic Aspects , 1954, Ejnar Mungksgaard, Copenhagen.

Karetu, T. Maori Proverbs. Revision of a work by A.E.Brougham and A.W.Reed, 1987, Reed Methuen, Auckland.

Kennedy J.C. Leadership and Culture in New Zealand, 2000, Lincoln University: New Zealand.

King, M. A Penguin History of New Zealand, 2003, Penguin Group, Auckland.

King, M. The Silence Beyond: Selected Writings by Michael King, 2011, Penguin Group (NZ),Auckland.

Leather, K \& R Hall. Tatai Arorangi: Maori Astronomy, Work of the Gods, 2004, Viking Sevenseas NZ Ltd, Paraparaumu.

Marsden, M. The Woven Universe: Selected Writings of Rev. Maori Marsden, 2003, The Estate of Rev. Maori Marsden, Masterton.

Mauri Ora, a free 12 month home-based learning resource about the history of Aotearoa/New Zealand available from Te Wananga o Aotearoa. www.openwananga.ac.nz

Mautner, Thomas. The Penguin Dictionary of Philosophy, 2000, Penguin Books, United States.

Miller, Fred. Rationality and Freedom in Aristotle and Hayek in Reason Papers No. 9 (Winter 1983) ,1983, Reason Foundation, United States.

Misa, T. NZ Herald 'Race problems unlikely to be solved in the bedroom,' www.nzherald.co.nz/nz/news/article.ctm?c_id=1\&objectid=10328363

Moon, P. Tohunga Hohepa Kereopa, 2003, David Ling Publishing Limited, Auckland.

Nettleship, R L. Lectures on the Republic of Plato, 1897, MacMillan and Co, London. 
Ngata, A \& P Te Hurinui, Nga Moteatea, 1959, The Polynesian Society, Auckland.

Ngata \& Buck, Na To Hoa Aroha: From Your Dear Friend, Correspondence 1925-1950. Edited by M Sorrenson. Three volumes, 1986-88, Auckland University Press, Auckland.

Ngata, H. English-Maori Dictionary, 1996, Learning Media, Wellington.

New Zealander Attitudes and Values (NZAVS) by Chris Sibley of the Department of Psychology, Auckland University. It began in 2009 and surveys the same 6000 people each year for a twenty year period. Its data backs up the 1988 New Zealander Values Survey view, that the terms Maori and Pakeha are relational. http://psych.auckland.ac.nz/uoa/new-zealand-attitudes-and-values-study Accessed $\underline{22 / 2 / 2012}, 3.52 \mathrm{pm}$.

Nicholas, D. Interviewee on RNZ National Saturday morning 2010, Sept 10 with Kim Hill.

Orange, C. The Treaty of Waitangi, 1987, Allen \& Unwin New Zealand Limited, Wellington.

Patterson, J. Exploring Maori Values, 1992, Dunmore Publishing Ltd, Wellington.

Patterson, J. People of the Land: A Pacific Philosophy, 2000, Dunmore Press, Palmerston North.

Pearson, D. A Dream Deferred, 1990, Allan \& Unwin, Wellington.

Peck, S. Further Along The Road Less Travelled, 1993, Simon \& Schuster, New York.

Perret, R \& J Patterson 1991, Virtue Ethics and Maori Ethics in Philosophy East and West 41, 1991,185202.

Perrett, R in R C Solomon and K Higgens (eds.) From Africa to Zen: An Invitation to World Philosophy, 2002, Rowman \& Littlefield, Lanham.

Penetito, W. Tree of Opportunity - rethinking Pacific education, 2002, University of South Pacific, Fiji.

Poata-Smith, E. Ka tika a muri ka tika a mua? Maori protest politics and the Treaty of Waitangi settlement process, in Tangata Tangata: Changing ethnic contours of New Zealand, C MacPherson \& D Pearson (eds.) 2004, Dunmore Press, Southbank Victoria.

Polynesian Society founded by Percy Smith and Elsdon Best and supported by Apirana Ngata.

Pou-Glavish, Naida. 2010: Maori Television: Tautohetohe , Auckland.

Radhakrishnan, S \& C Moore(eds.) History of Philosophy Eastern and Western Volume One, 1952, Allen \& Unwin, London.

Raerino, N 1999, Koi Ro Pure Me Karakia E Oke Ana, 1999, Auckland University, Auckland.

Reed, A. Reed Concise Maori Dictionary, 1949, Reed, Wellington.

Reed, A (compiled). T.Karetu (revised). Concise Maori Dictionary, 1984, A. Reed Ltd, Wellington. 
Reedy, Amsterdam, a contemporary tohunga (ritual expert).

Riley, M. Maori proverbs and Sayings, 1990, Viking Sevenseas, Paraparaumu.

Runes, D (ed.). Dictionary of Philosophy, 1983, Philosophical Library Inc., New York.

Ruse, Dictionary of Philosophy, 1979.

Saifulin, M \& R Dixon (eds.) Dictionary of Philosophy, 1984, Progress Publishers: United States of America.

Sansome, R (compiled) D.Reid (revised). The Oxford Junior Dictionary, 1988, Oxford University Press, Oxford.

Sen, Amartya, The Argumentative Indian, 2005, Penguin Group, London. Shanbhag, D in History of Philosophy Eastern and Western Volume One, 1952, Allen \& Unwin, London.

Shaw, J. Man and Freedom: A Comparative Study, in Bulletin of the Ramakrishna Mission Institute of Culture, 2000, Ramakrishna Mission Institute, Calcutta.

Shaw, J. Swami Vivekananda As A Philosopher, 2004, Ramakrishna Mission Institute of Culture, Kolkata.

Shaw, J. Freedom: East and West, 2011, Sophia, published online 26 April 2011.

Shiva, V. Staying Alive: Women, Ecology and Development , 1988, Zed Books, London.

Sibley, C. New Zealand Attitudes and Values Study, 2009, Dept. Psychology, University of Auckland. http://psych.auckland.ac.nz/uoa/new-zealand-attitudes-and-values-study

Starting Point Study Bible, 2002, Zondervan, USA.

Statistics New Zealand, Hot Off The Press, Series 5, 2007 October, Statistics New Zealand, Wellington.

Statistics New Zealand, 2001 Census: Iwi (2001) - reference report, 2001, Statistics New Zealand, Wellington.

Stanford Encyclopedia of Philosophy, http://stanford.edu/entries

Starting Point Study Bible, 2002, Zondervan, USA.

Szaszy, Miraka. Seek the Seeds for the Greatest Good for All People: Maori Graduands Capping Ceremony 28 April 1993, 1993, Victoria University, Wellington.

Tapine, V. Building Research Capacity within Maori Communities, Proceedings of a wananga, 12 July 1999, Wellington, New Zealand Council for Educational Research, 2000.

Tuhiwai-Smith, L, A Jones, H Marshall, K Morris Matthews, G Smith. Myths \& Realities: Schooling in New Zealand ( $2^{\text {nd }}$ Edition), 1995, The Dumore Press Limited, Palmerston North. 
Turia, T. MP \& Maori Party co-leader, press release Nov 1, 2001, www.maoriparty.org.nz accessed Feb 20, 2012, 10.26pm

Vivekananda, S. In The Complete Works of Swami Vivekananda, Ramakrishna Mission Institute of Calcutta, Calcutta.

Waitangi Tribunal, http://waitangi-tribunal.govt.nz/news/closingdateforsubmissionsofhistoricalclaims/

Waitangi Tribunal: Muriwhenua Fishing Report, 1988, Department of Justice, Wellington.

Walker, R. The Relevance of Maori Myths and Tradition in King M, Tihei Mauri Ora: Aspects of Maoritanga, 1978, Methuen, New Zealand.

Walker, R. Ka Whawhai Tonu Matou/Struggle Without End, 1990, Penguin, Auckland.

Walker, R. Nga Pepa a Ranginui, 1996, Penguin Books, Auckland.

Webster, A. Spiral of Values: The flow from survival values to global consciousness in New Zealand, 2001, Alpha Publications, Hawera.

White, S. The Cambridge Companion to Habermas, 1995, Cambridge University Press: Cambridge.

Whitehead, A, D Griffin \& D Sherburne (eds.) Process and Reality -an essay in cosmology, 1979, Free Press, New York.

Williams, H. Dictionary of the Maori Language, 1971, Legislation Direct, Wellington.

Wood, D (ed.). On Paul Ricoeur: Narrative and Interpretation, 1992, Routledge, London.

Whaanga, P. The nature of bi-cultural beings in Aotearoa or notes about the New Zealanders I live with (unpublished), 2009, Victoria University, Wellington.

Wittgenstein, L. Philosophical Investigations, 2001, Blackwell, Oxford. 


\section{MAORI LANGUAGE APPENDIX}

Source: Concise Maori Dictionary, compiled by A.W.Reed, revised by T.S.Karetu, 1984, Reed Publishers, Wellington.

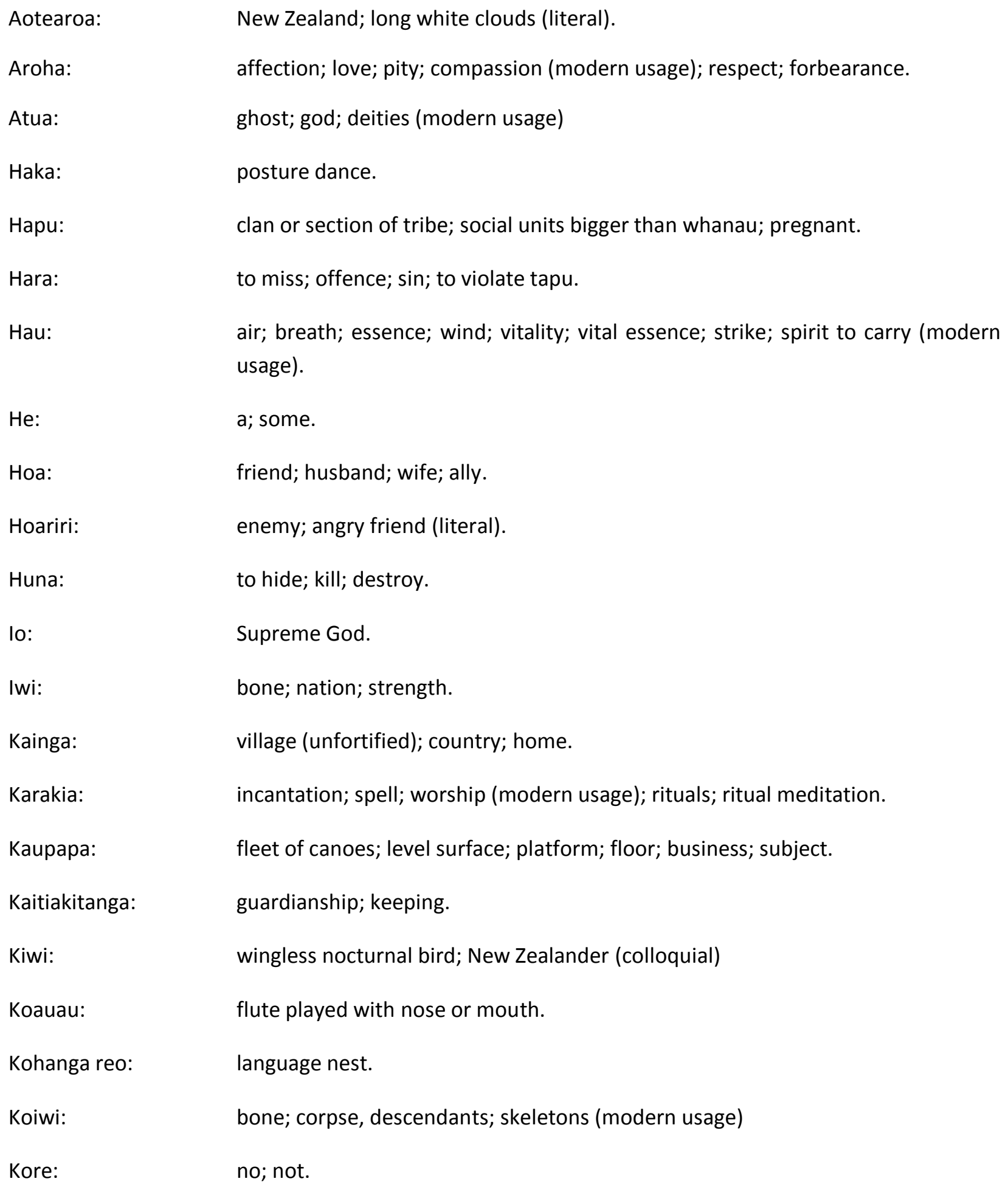




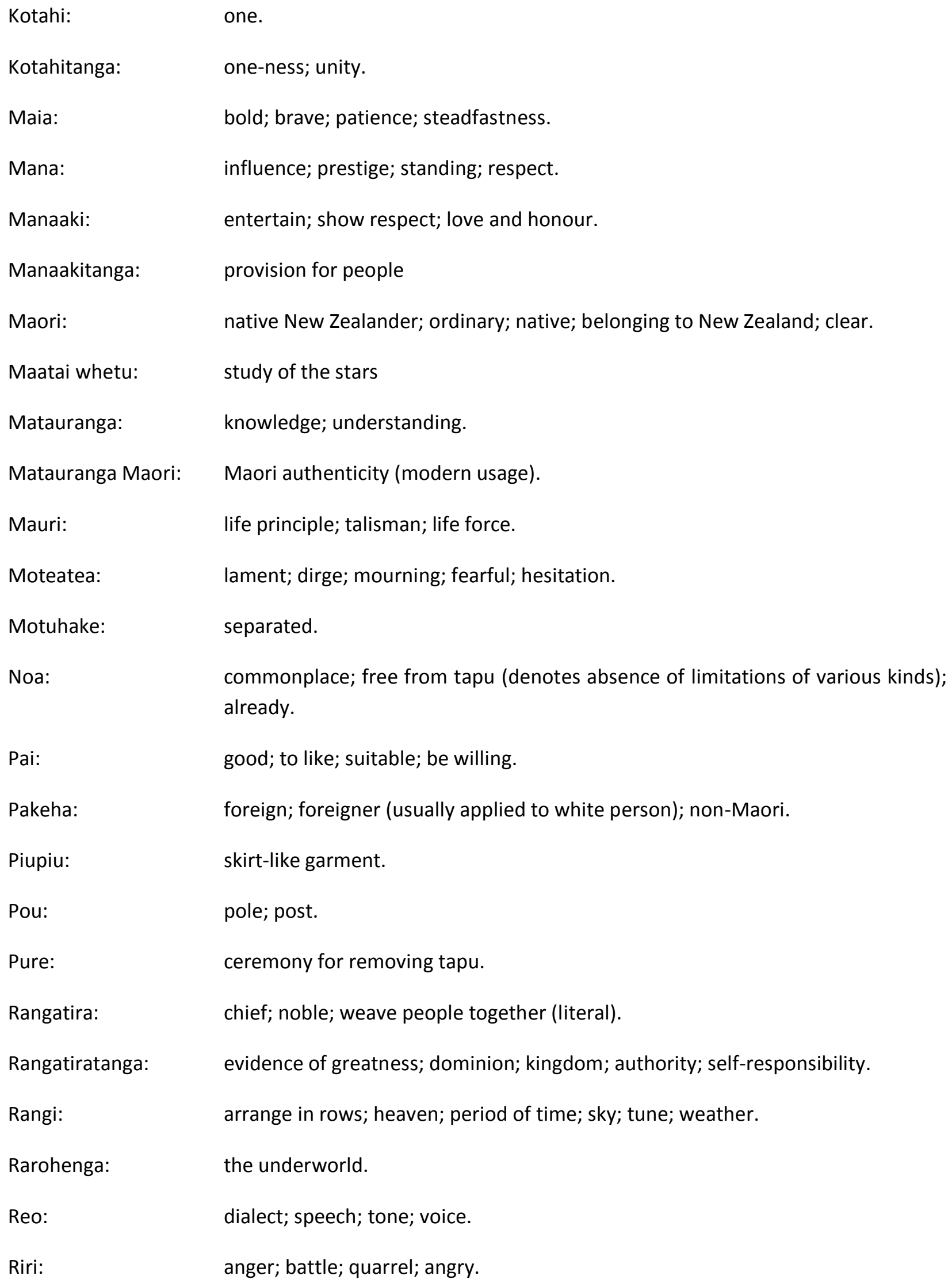




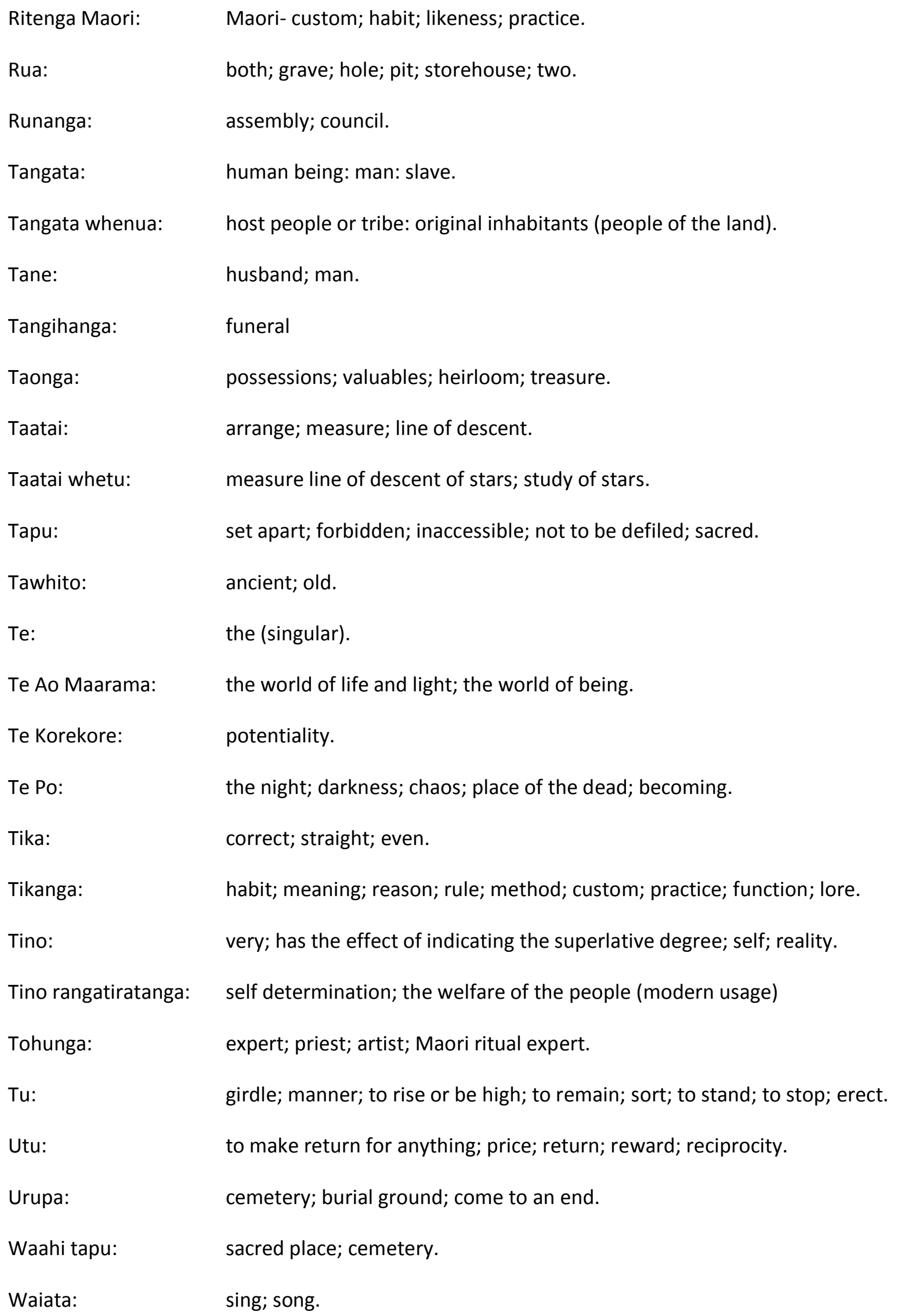




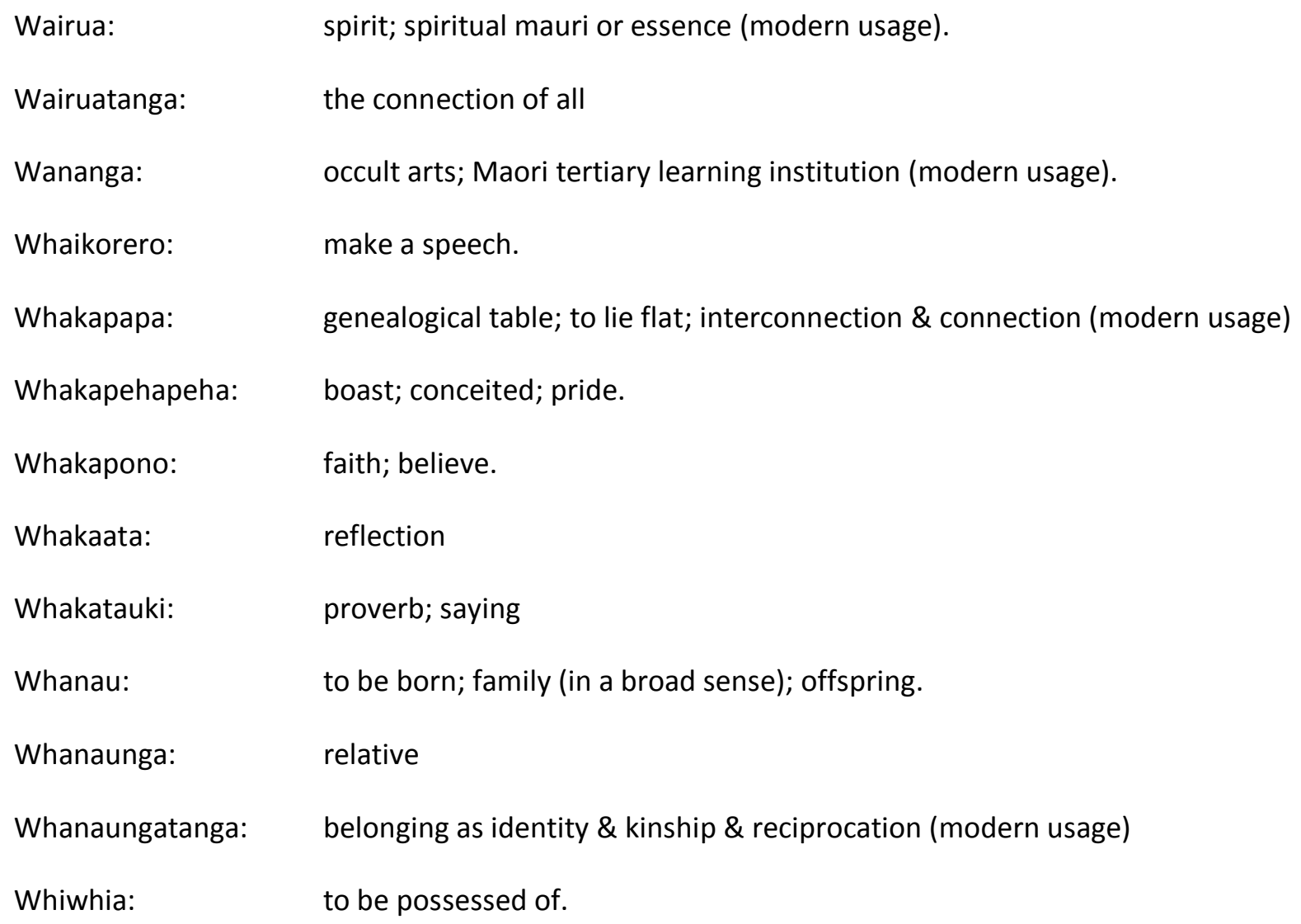

